\title{
Tracing the Eocene-Oligocene transition: a case study from North Bohemia
}

\author{
ZLATKO KVAČEK, VASILIS TEODORIDIS, KAREL MACH, TOMÁŠ PŘIKRYL \& ZDENĚK DVOŘÁK
}

\begin{abstract}
Geology and palaeontology of the Roudníky area, situated between the Most Basin and the České středohoří Mountains in North Bohemia, the Czech Republic, is treated in detail. The volcano-sedimentary structure underlying the basin with the included fossiliferous layers is newly interpreted as a maar-diatreme. The radiometric age of the basalts was determined to $35.4 \pm 0.9 \mathrm{Ma}$ and $37.1 \pm 0.9 \mathrm{Ma}$ - late Eocene, Priabonian. The fish fauna consists of amiids characteristic of other adjacent late Eocene sites while the co-occurring macroflora includes many elements that are typical of the Oligocene. Closest relations are to the fauna and flora of the Větruše Hill at Ústí nad Labem. Based on palaeoclimatic estimates the major turnover from subtropical to warm-temperate climatic regimes in North Bohemia appears to have initiated in the late Eocene by an increase of seasonality and the resulting vegetation change from the evergreen to mixed mesophytic forest types well before the maximum temperature drop of mean annual temperature at $c a 33.5$ Ma. $\bullet$ Key words: flora, fauna, climate, vegetation, late Eocene, early Oligocene, boundary.
\end{abstract}

KVAČEK, Z., TEODORIDIS, V., MACH, K., PŘIKRYL, T. \& DVOŘÁK, Z. 2014. Tracing the Eocene-Oligocene transition: a case study from North Bohemia. Bulletin of Geosciences 89(1), 21-66 (13 figures, 3 tables, 3 appendices). Czech Geological Survey, Prague. ISSN 1214-1119. Manuscript received January 28, 2013; accepted in revised form October 10, 2013; published online December 12, 2013; issued January 21, 2014.

Zlatko Kvaček (corresponding author), Institute of Geology and Palaeontology, Faculty of Science, Charles University in Prague, Albertov 6, 12843 Prague 2, Czech Republic; kvacek@natur.cuni.cz・Vasilis Teodoridis, Department of Biology and Environmental Studies, Faculty of Education, Charles University in Prague, M.D. Rettigové 4, 11639 Prague 1, Czech Republic; vasilis.teodoridis@pedf.cuni.cz • Karel Mach \& Zdeněk Dvořák, Severočeské doly (North-Bohemian Mines) a.s., ul. 5. května 213, 41829 Bílina, Czech Republic; Mach@sdas.cz, Dvorak@sdas.cz・ Tomáš Přkryl, the same address as the first author, and Institute of Geology, Academy of Sciences of the Czech Republic, v.v.i., Rozvojová 269, 16500 Prague 6, Czech Republic; prikryl@gli.cas.cz.

The palaeoclimatic event at the Eocene-Oligocene transition has attracted the attention of many palaeobotanists and researchers of palaeoenvironmental science (e.g., Collinson 1992, Collinson et al. 2010, Kvaček 2010, Teodoridis et al. 2012). In general, the pronounced cooling in this time interval (e.g., Zanazzi et al. 2007, Hren et al. 2013) induced also changes in palaeovegetation, although this event manifested variously in the mid-northern lalitudes (Mai 1995, Graham 1999, Akhmetiev et al. 2009). In this paper we will contribute to the disscusion on this topic (Katz et al. 2008, Eldrett et al. 2009) and offer new palaeontological datasets based on the radiometrically ( $\mathrm{K}-\mathrm{Ar}$ ) dated fossil plant and fish assemblages from North Bohemia that may add information on the timing and overall character of this event in Central Europe. This study includes revisions of the previously published tentative data (Bellon et al. 1998, Akhmetiev et al. 2009), supplemented by newly collected material from the same area at Roudníky. Much attention is devoted to exact evaluation of the geological position of the recovered fossils from the edge of the Most Basin and the České středohoří Mountains. More stress is also given to obtain objective pa- laeoenvironmental signals from plant assemblages of the late Eocene to early Oligocene deposits of North Bohemia and Saxony by newly developed techniques, i.e., Integrated Plant Record Vegetation Analysis, Leaf Margin Analysis, Climate Leaf Analysis Multivariate Program and Coexistence Approach. The recently published monographs on the Eocene and Oligocene plant records in Central Europe (e.g., Walther \& Kvaček 2007, Kvaček \& Teodoridis 2011) allow us to correlate the studied sites more precisely.

The authors participated on the text as follows: Karel Mach and Zdeněk Dvořák - geology, Zlatko Kvaček and Vasilis Teodoridis - palaeobotany, Vasilis Teodoridis palaeoenvironmental interpretations, Tomáš Přikryl zoopalaeontology.

\section{Geological setting}

The village of Roudníky is situated on the border of the Ústí part of the Most Basin and the České středohoří Mts approximately $10 \mathrm{~km}$ southwest from the town of Ústí nad 


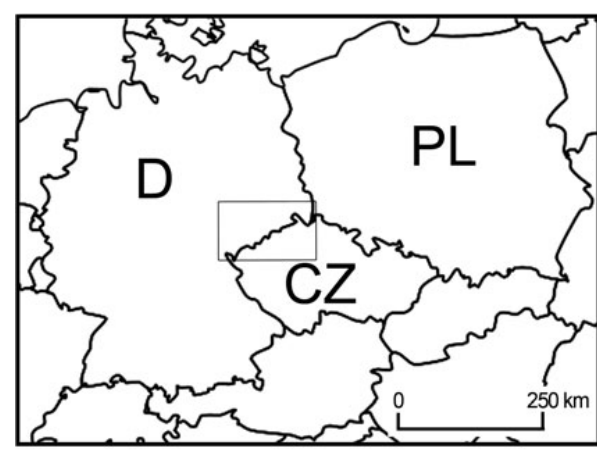

Figure 1. Location of the studied floras in Northern Bohemia and Saxony. Floras/sites: 1 - Nový Kostel, 2 - Český Chloumek, 3 - Staré Sedlo, 4 - Kučlín, 5 - Haselbach, 6 - Profen, 7 - Klausa, 8 - KaynaSüd, 9 - Knau, 10 - Roudníky, 11 - Větruše, 12 - Böhlen, 13 - Valeč, 14 - Haselbach, 15 - Regis, 16 - Beucha, 17 - Bechlejovice, 18 - Kundratice, 19 - Hammerunterwiesenthal, 20 - Holý Kluk, and 21 - Seifhennersdorf. Symbols: "squares" - late Eocene sites, "circles" - early Oligocene sites.

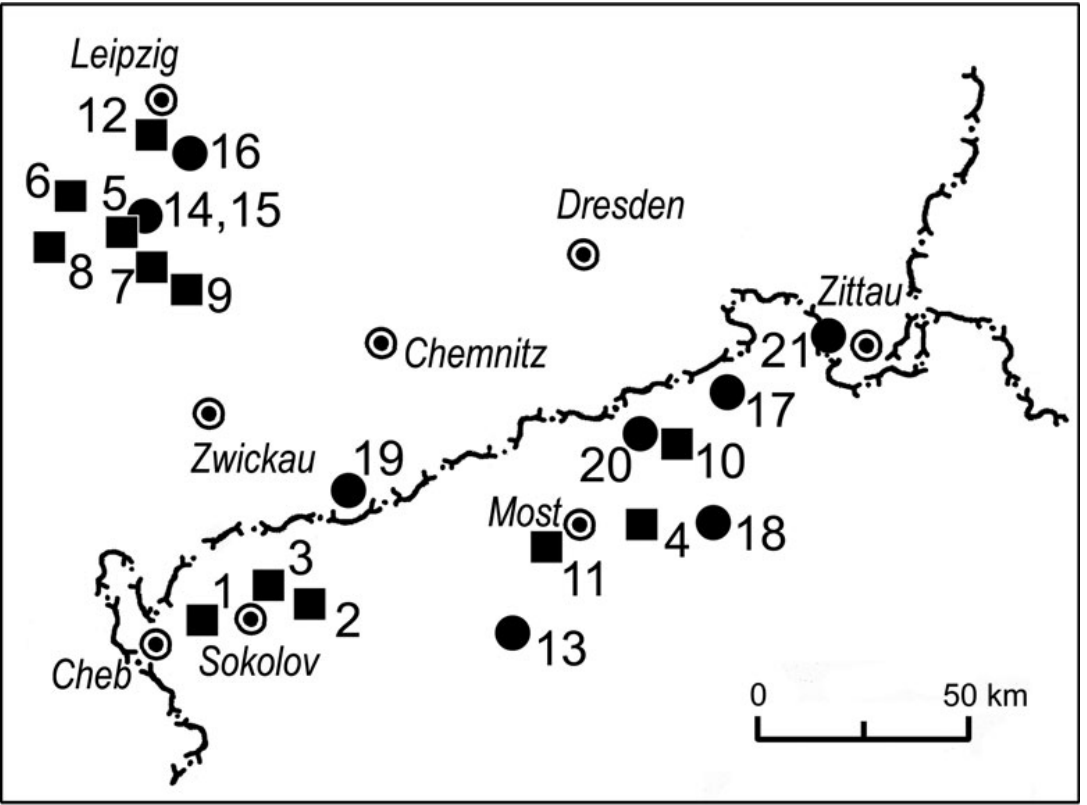

Labem. The fossils described in this paper come from several deep drill-cores in the vicinity of Roudníky (Figs 1,2A) and from two outcrops southeast of the village (Fig. 2F, G). Most of the drill-cores that yielded fossils are located in the area within the Miocene fill belonging to the Most Formation of the Most Basin. The studied fossiliferous strata belong to the underlying volcano-sedimentary unit - the Střezov Formation of late Eocene to Oligocene age. Until 1992 the geology of the Roudníky area was known only from several drill-cores, and from the data of historical underground mining and working of the adjacent coal opencast mine. During 1990-1992, the geologic setting of the Roudníky area was studied in detail by a team of authors that issued the final report on coal deposit Chabařovice II reserves calculation (Vácha et al. 1992). During the prospection stage of their work several tens of new boreholes were made and the cores were examined by many specialists. A unique feature of the drilling program was the fact that many of boreholes reached not only the bottom of the Miocene coal seam, as necessary for the coal reserves calculation, but continued under the bottom of Miocene sediments or Eocene to Oligocene volcanic rocks and often reached even the contact with Cretaceous sediments (Fig. 2A-E). Use of complex methods during the drill-core evaluation and geophysical methods led to an extraordinarily high degree of understanding about subsurface geological structure and development of the area. Information on the general geological position of the deposit is given in the state geological map 1:25,000 sheet 02-322 Krupka and its explanative text (Jiránek 1991).

The Palaeogene fossil-bearing volcano-sedimentary units that are treated here belong either to the Střezov Formation or the volcano-sedimentary complex of the České středohoři Mts. In the vicinity of Roudníky the Střezov Formation consists mainly of various types of tuffs, tuffites and tuffitic clays, volcanic breccias and basaltic (olivinic basalts, basanites, nefelinites) or trachytic to phonolitic lavas. Many of these volcanic products are strongly weathered, changed into a tens-of-meters-deep kaolinic to smectitic weathering crust. Volcanic products are associated by several more or less continuous layers of clayey sediments. Clays rich in organic matter, rarely calcareous or diatomaceous clays, form several decimeters to $2.5 \mathrm{~m}$ thick deposits passing both laterally and vertically into tuffitic clays, tuffites or just tuffs, partly into thin coal seams. Some of them are very similar to early Miocene clays from the coal seam overburden (Cajz 1990). These clastic sediments are often laminated, containing various fossils (Bůžek 1990, Bellon et al. 1998). Among animal remains, freshwater bivalves, gastropods, crustaceans, insects, fishes, rare frogs, vertebrae of deer, teeth and coprolites of crocodiles (the last three mentioned items known from Větruše only) were identified. In the northern part of the Roudníky area products of volcanism are covered by early Miocene sediments of the Most Formation (Čadek et al. 1990). Several hundred meters east from

Figure 2. A - geological map of the Roudníky area (contour lines show a terrain state before mining); B - stratigraphic column of the Roudníky area; C-geological cross section 1-2; D - geological cross section A-B; E - explanation to Fig. 2A-D; F, G - outcrops of Roudníky. 
Zlatko Kvaček et al. • Eocene-Oligocene transition in North Bohemia
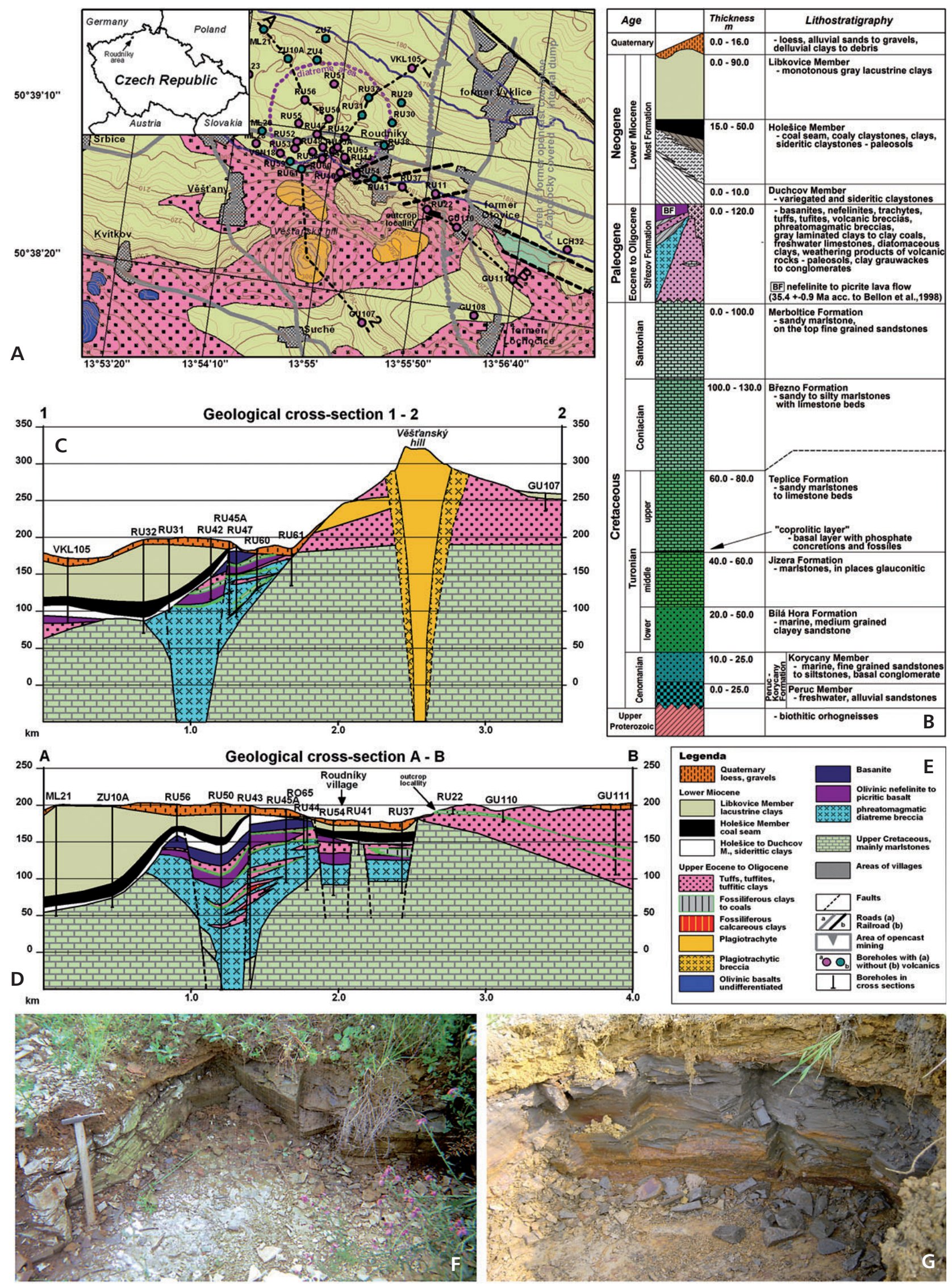
the village, this early Miocene coal deposit was completely exhausted by the huge opencast mine Chabařovice (former A. Zápotocký) during the 70 s to 80 s of the $20^{\text {th }}$ century. Today the exploited part of the coal deposits is filled by removed overburden clays. The mine was closed in 1993 and today an extensive lake arose in its deepest part and the area is completely reclamed without any perspective of future mining.

The studied fossiliferous layers were documented mainly by drill-cores. They are represented by coals, bituminous clays, calcareous clays, diatomaceous clays, tuffitic clays and tuffites and reach from several $\mathrm{cm}$ to $2.5 \mathrm{~m}$ in thickness. The layers belong to the volcano-sedimentary unit of late Eocene to Oligocene age, partly called the Střezov Formation sensu Domácí (1977) and to the Ústí and Děčín formations of the České středohoří Mts sensu Cajz (1999, 2000). In fact we can consider the Střezov unit as a lateral continuation of the České středohoří units under the early Miocene cover. These units were dated by the ${ }^{40} \mathrm{~K}-{ }^{40} \mathrm{Ar}$ method (Bellon et al. 1998). The age of the analyzed sample of basaltic rock from the drill-core RU 60 (depth $21.4 \mathrm{~m}$ ) was determined as $35.4 \pm 0.9 \mathrm{Ma}$ and $37.1 \pm 0.9 \mathrm{Ma}$ corresponding to the Priabonian, late Eocene.

The newly proposed interpretation of the volcano-sedimentary structure, which includes fossiliferous layers, envisages a maar-diatreme structure. Earlier interpretations by Cajz (1990) did not recognize the maar-diatreme structure in spite of noting breccias and tuffaceous rocks associated with a high content of xenolithic material formed by Cretaceous marlstones, late Proterozoic gneisses and Cainozoic clays. This previous interpretation generally led to an idea of repeated volcanic eruptions into the water basin accompanied by tectonic subsidence of the basin. Phreatomagmatic diatreme breccias that form majority of the diatreme body were described as a hyaloclastite or pepperite (Cajz 1990). The reinterpretation of drill-core material and maps of coal seam structure (Vácha et al. 1992) allows to supporte the new concept of the maar - diatreme structure by the following facts: (1) the circular form of the structure in plan - see Fig. 2A; (2) funnel-shape form of the body of breccias (Fig. 2C, D); (3) composition of breccia - high contents of xenoliths; (4) downward coarsening of dimensions of breccia fragments; (5) internal inclination of sedimentary layers to the center of the structure; (6) presence of the central depression originated by diagenetic subsidence of the central part filling; (7) the presence of two thick basalt lava bodies overlying lacustrine to palustrine clay and coal sediment on the top of the maar-diatreme structure; and (8) occurrence of laminated fossiliferous layers within the maar. All these facts do not exclude the possibility of surface water sources or small basins in the area during volcanic activity and documented reaction of ba- saltic magma with the water either in the depth or on the surface of the maar lake.

The large maar-diatreme structure (Fig. 2C, D) has a champagne glass form (Lorenz 2003) typical for diatremes formed in relatively soft rock environments. In that topmost part the diameter of the structure reaches more than $1 \mathrm{~km}$, while at the depth of $250 \mathrm{~m}$ it looks very narrow (100-150 m). Two continuous distinct basaltic bodies were documented in the studied drill-cores. The upper basaltic body, reaching a thickness of $15 \mathrm{~m}$, is formed by basanite (Mag 1992) the lower one has the similar thickness and is formed by picritic basalt (Bellon et al. 1998) to olivinic nefelinite (Mag 1992). Both basalt bodies are separated by the upper fossiliferous layer of tuffites and clays. These bodies form the youngest volcanic filling (lava lakes) of the maar-diatreme structure and in fact they saved the maar-diatreme filling and fossiliferous deposits from more intensive destruction by erosion. The two fossiliferous horizons are developed in such a way that the lower one is covered by lower basaltic body and the upper one is localized between the lower and upper basaltic body. Other basalt occurrences within the maar-diatreme structure found in the drill-core profiles are much smaller in dimensions and have very irregular position within the profile. Three other irregular fossiliferous horizons under the basaltic bodies within the brecciated fill of the maar are localized only in its upper widening part. According to clay composition, laminated textures and content of fish scales, all the fossiliferous layers represent products of lacustrine and also palustrine (coal facies) environments. The deepest position has the layer of calcareous clays with remains of gastropods (drill-core RU 43, depth 110-165 m), while the deepest localized organic-rich layer is known from the central part of the diatreme depression (drill-core RU 50, depth 141.25-143.00 m). The position and correlation of the fossiliferous clays in the drill-cores and the outcrop SE from Roudníky is uncertain being partly based only on local correlation by the palaeontological markers (Juniperus pauli, Cyclurus sp.).

Several fossil localities are known in the wider surroundings of Roudníky that roughly correspond to this site. Fossiliferous clay and diatomite of the Větruše Hill $10 \mathrm{~km}$ to the east from Ústí nad Labem (see Radoň 2001) has yielded fossil plants and fish remains of amiids. This locality is characterized by $25 \mathrm{~cm}$ thick diatomaceous clay layer outcropping between two basaltic bodies similar to the Roudníky locality. The profile at Větruše was proposed as the holostratotype of the Ústí Formation (Cajz 2000) and the aquatic environment during the effusion was mentioned. The position and the association of fossils recovered in this clay layer partly coincide with those recovered in the Roudníky area (see below). 


\section{Material and methods}

Palaeontological material of Roudníky was collected from the drill-cores by the late Čestmír Bůžek and the first author during the geological exploration in 1987-1989. Later, Zdeněk Dvořák and his brother Pavel Dvořák during the years 1996 to 2003 succeeded to get important fossils from the outcrops. The plant fossils are preserved partly as compressions in pellitic volcanogenic deposits. Most of the specimens are housed in the collections of the National Museum in Prague (NM G, NM Pc), the others are in private collections of Zdeněk Dvořák (ZD), and the Regional Museum in Teplice (RMT).

In case of coaly leaf material attempts have been made to macerate cuticles by a routine technique of Schulze mixture. However, surface of most compressions are finely fractured due to desiccation, so that only well cutinized (evergreen) foliage yielded satisfactory structures.

To get independent palaeoenvironmental proxy-datasets for a comparison and validation of the Roudníky flora within the studied late Eocene to early Oligocene fossil floras/vegetation types of the Bohemian Massif and Saxony (Germany), five different palaeoenvironmental methods of Phytosociological approach, Integrated Plant Record vegetation analysis (IPR-vegetation analysis), Leaf Margin Analysis (LMA), Climate Leaf Analysis Multivariate Program (CLAMP) and Coexistence Approach (CA) have been used. The phytosociological approach (for details see Mai 1995) and IPR-vegetation analysis (e.g., Kovar-Eder et al. 2008; Teodoridis et al. 2011a, b) help to evaluate the studied plant assemblages. The other techniques were used to predict palaeoclimatic proxy-datasets based on physiognomic characters of foliage (LMA, CLAMP) and environmental requirements of the nearlest living relatives (CA) of the studied fossil floras. The present study used linear regression equations by Wolfe $(1979)-\mathrm{LMA}_{\mathrm{MAT} 1}=30.6 \times \mathrm{P}+1.41$; $\left(\mathrm{r}^{2}=0.98\right)$, and by Su et al. $(2010)-\mathrm{LMA}_{\mathrm{MAT} 2}=27.6 \times \mathrm{P}+$ 1.038; $\left(\mathrm{r}^{2}=0.79\right)$ for LMA method, where MAT (mean annual temperature), $\mathrm{P}$ (proportion of $\mathrm{n}$ species with entire margin, $0<\mathrm{P}<1$ ) and $\mathrm{r}^{2}$ (coefficient of determination). To verify the obtained estimates, the value of sampling errors (SE1) and (SE2) were calculated following Wilf $(1997)-\mathrm{SE} 1_{\mathrm{MAT}}=\mathrm{c} \sqrt{ }([(\mathrm{P}(1-\mathrm{P})) / \mathrm{n})]$ and Miller et al. (2006) $-\mathrm{SE} 2_{\mathrm{MAT}}=\sqrt{ }([1+\varphi(\mathrm{n}-1) \mathrm{P}(1-\mathrm{P})] \times(\mathrm{P}(1-\mathrm{P})) / \mathrm{n})$, where the following symbols are used: $\mathrm{c}$ (slope of the MAT vs. leaf margin regression, equals 30.6 here), $\mathrm{n}$ (total species number), $\mathrm{P}$ (proportion of $\mathrm{n}$ species with entire margin, $0<\mathrm{P}<1$ ) and $\varphi=0.052$ (dispersion factor). An updated version (see Teodoridis et al. 2012) of the special tool developed by Teodoridis et al. (2011c) was used to select relevant physiognomical datasets for using CLAMP, as characterized by e.g., Wolfe \& Spicer (1999), Spicer et al. (2009), and Yang et al. (2011). Physiognomic characteristics of the studied floras are presented in Appendix 1.
The lastly used palaeoclimatic technique was Coexistence Approach (CA) developed by Mosbrugger \& Utescher (1997) and updated by Utescher et al. (2000).

\section{Systematic palaeontology}

The arrangement of plant taxa corresponds to the phylogenetic system based on molecular phylogeny (Judd et al. 2002, Christenhusz et al. 2011, Reveal 2012).

Plantae

Conifers

Family Pinaceae

\section{Genus Pinus L.}

\section{Pinus sp.}

Figure 3A, B

Material. - Seeds, outcrop (ZD RUP 79a, 90).

Description. - One of the winged conifer seeds available is clearly assignable to Pinus because of the laterally adhearing large seed and only slightly constricted wing (cf. Wolfe \& Schorn 1990, pp. 7-8). Specific determination is equivocal because of very limited amount and incompleteness of material. The other specimen shows only the wing without the seed part.

\section{Family Cupressaceae}

\section{Genus Juniperus L. sect. Sabina (Mill.) Spach}

\section{Juniperus pauli Kvaček}

Figures 3C, 7K

2002a Juniperus pauli Kvaček, p. 493, figs 1-3.

2009 Juniperus pauli Kvaček; Akhmetiev et al., p. 95, pl. 9, fig. 4.

Material. - Fertile twigs, outcrop (NM G 7904a and ZD RUP 6B - holotype and counterpart), sterile twigs and fragments, isolated male cones and seeds, drill-cores RU 44, depth 18 m (NM G 8777, G 8783), RU 60, depth 27.5-28 m (NM G 9412b - RU 60-7, NM G 9416, G 9417, RU 60-1), outcrop (ZD RUP 1A, B, 2, 3A, B, 4A, B, 5A).

Description. - The juniper from Roudníky is the earliest record of this genus in Europe. It is endemic in the North Bohemian Palaeogene, where it occurs besides Roudníky also at the Větruše Hill at Ústí/L. (pl. 9, figs 1-3; for detailed treatment see Kvaček 2002a). Its holotype represents a 
fertile twig on a slab with attached seed cones confirming the affinity to the multi-seeded group of sect. Sabina Spach with smooth-edged leaves. The detached coaly twig fragments from drill-cores yielded epidermal anatomy corresponding to the Mediterranean $J$. thurifera L. The multiseeded cones are similar to those of Juniperus thurifera var. thurifera distributed in the mountains of Spain and French Alps (Adams 2008).

\section{Genus Taxodium Rich.}

\section{Taxodium dubium (Sternberg) Heer} Figures 3D-F, 7L

1853 Taxodium dubium (Sternberg) Heer, p. 136.

2009 cf. Taxodium dubium (Sternberg) Heer; Akhmetiev et al., p. 95, pl. 9, fig. 5 .

Material. - Sterile twigs, outcrop (ZD RUP 50, 93, 94, 95), partly with epidermal anatomy, drill-cores RU 43, depth 116.3 m (NM G 8810), RU 48, depth 16 m (NM G 8793b RU 48-11B, NM G 9441 - RU 48-12), RU 60, depth 47.5-50 m (NM G 9427 - RU 60-20).

Description. - Sterile taxodioid foliage recovered at Roudníky belongs according to the epidermal anatomy to Taxodium: thin-walled quadrangular non-modified cells with smooth anticlines, amphicyclic stomata mostly perpendicularly oriented to the leaf midrib, with narrow elongate pit (Kunzmann et al. 2009). A morphologically similar Eocene conifer Chamaecyparites hardtii (Göpp.) Endl. emend. Kunzmann differs in epidermal anatomy by widely scattered, mostly longitudinally arranged amphicyclic stomata with darker cutinized subsidiary cells (Kunzmann 1999).

\section{Genus Tetraclinis Masters}

\section{Tetraclinis salicornioides (Unger) Kvaček} Figures 3G, H, 7M

1989 Tetraclinis salicornioides (Unger) Kvaček, p. 48, pl. 1, fig. 11, pl. 2, figs $2-14$, pl. 3, figs $1-4$, text-fig. 1 .

Material. - Twig fragments, drill-core RU-60, depth 28-28.5 m (NM G 9420a-c, unnumbered).

Description. - The cladode-like foliage of this conifer represented at Roudníky by the compressions with epidermal structure differs from the similar Cretaceous to early Palaeogene Ditaxocladus S.X. Guo \& Z.H. Sun by thick papillate cuticles showing irregularly scattered stomata with very pronounced Florin rings (Guo et al. 2012). Similar records are known from the European Palaeogene and Neogene, more rarely from the Oligocene and Miocene of North America (Kvaček et al. 2000).

Family Taxaceae

\section{Genus Cephalotaxus Siebold \& Zucc.}

\section{cf. Cephalotaxus parvifolia (Walther) \\ Kvaček \& Walther \\ Figure 3I}

? 1998 Cephalotaxus parvifolia (Walther) Kvaček \& Walther, p. 11, pl. 4, figs 1-3.

Material. - Isolated needle, outcrop (ZD RUP 80).

Figure 3. Locality Roudníky. • A - Pinus sp., seed, ZD RUP 79a. • B - Pinus sp., seed, ZD RUP 90. C - Juniperus pauli Kvaček, branch with seed cone, holotype, NM G7904a. • D - Taxodium dubium (Sternberg) Heer, leafy twig, NM G 8793, RU48-11B. • E - Taxodium dubium (Sternberg) Heer, leafy twig, ZD RUP 50. F - Taxodium dubium (Sternberg) Heer, leafy twig, ZD RUP 93. $\bullet \mathrm{G}-$ Tetraclinis salicornioides (Unger) Kvaček, two leafy segments, NM unnumbered, RU 60 • H - Tetraclinis salicornioides (Unger) Kvaček, leafy segment, NM G 9420a, RU 60. • I - ?Cephalotaxus parvifolia (Walther) Kvaček \& Walther, incomplete needle, ZD RUP 80. • J - Torreya bilinica Saporta \& Marion, leafy branch with two needles, ZD RUP 61. • K - cf. Sabrenia sp., seed, NM G 9448, RU 44. • L - cf. Sabrenia sp., seed, NM G 9449a, RU 44. • M - cf. Sabrenia sp., detail of testa, NM G 9448 , RU 44. • N - cf. Sabrenia sp., structure of testa, NM G 9449a, RU 44. • O - Laurophyllum acutimontanum Mai, leaf compression, NM G $9404 a$, RU 60. -P - Laurophyllum acutimontanum Mai, fragmentary leaf, NM G 8808a, outcrop. $\bullet \mathrm{Q}-$ Laurophyllum acutimontanum Mai, leaf impression with cuticle, NM G 8786a, RU 44. - R - Laurophyllum pseudoprinceps Weyland \& Kilpper, fragmentary leaf compression, NM G 8772a, RU 44-9A. -S - Laurophyllum pseudoprinceps Weyland \& Kilpper, fragmentary leaf compresssion, NM G 8762a, RU 43-1. • T - Laurophyllum pseudoprinceps Weyland \& Kilpper, leaf base, NM G 8809a, outcrop. • U - Liriodendron sp., winged samara, ZD RUP 63A. • V - Liriodendron sp., winged samara, ZD RUP 28. • W - Platanus neptuni (Ettingshausen) Bůžek, Holý \& Kvaček, leaf impression, ZD RU 12A. • X - Platanus neptuni (Ettingshausen) Bůžek, Holý \& Kvaček, leaf apex with preserved epidermal anatomy, NM G 8794a, RU 48-10. • Y - Platanus neptuni (Ettingshausen) Bủžek, Holý \& Kvaček, entire-margined leaf apex, NM G 9403a, RU 60-9. - Z - Tilia brassicoides (Saporta) Kvaček \& Walther, bract, ZD RUP 133. - A* - Cercidiphyllum crenatum (Unger) R. Brown, rounded leaf of mature branch, NM G 9414a, RU 60-13.A. • B* - Cercidiphyllum crenatum (Unger) R. Brown, petiolate rounded leaf, ZD RUP 105. - $C^{*}-$ Cercidiphyllum crenatum (Unger) R. Brown, leaf with acute apex, ZD RUP 18. - D* - Cercidiphyllum crenatum (Unger) R. Brown, cluster of fruits, ZD RUP 22A. $\bullet \mathrm{E}^{*}-$ cf. Matudaea menzelii Walther, petiolate leaf impression, ZD RUP 134. $\bullet \mathrm{F}^{*}$ - Cercidiphyllum crenatum (Unger) R. Brown, winged seed, ZD RUP 89. Scale bars: A-J, O, P, R-V, Z-E* $=5 \mathrm{~mm} ; \mathrm{K}, \mathrm{L}=1 \mathrm{~mm}$; $\mathrm{M}, \mathrm{N}=50 \mu \mathrm{m} ; \mathrm{Q}, \mathrm{W}-\mathrm{Y}=10 \mathrm{~mm} ; \mathrm{F}^{*}=3 \mathrm{~mm}$. 
Zlatko Kvaček et al. • Eocene-Oligocene transition in North Bohemia
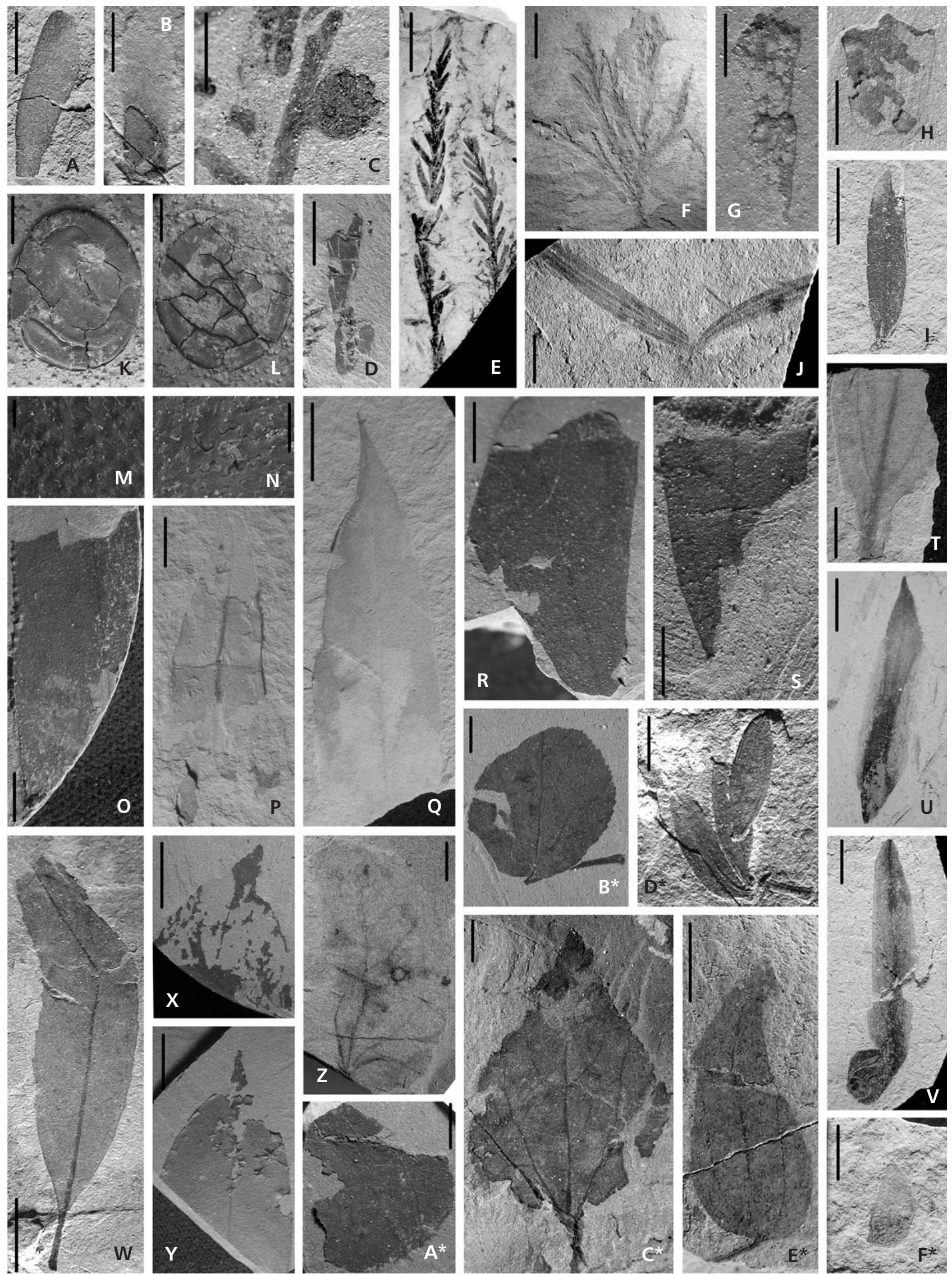
Description. - Due to absence of epidermal traits the identification of this single needle is not straight-forward. Noteworthy are invisible stomatal bands on the impression. Similar sterile remains occurring in the Oligocene of North Bohemia and Saxony (Seifhennersdorf, Kundratice - Kvaček \& Walther 1998, Walther \& Kvaček 2007) have been assigned to Cephalotaxus on account of stomatal topography and match in gross morphology.

\section{Genus Torreya Arnott}

\section{Torreya bilinica Saporta \& Marion} Figure 3J

1876 Torreya bilinica Saporta \& Marion, p. 221.

2009 Torreya bilinica Saporta \& Marion; Akhmetiev et al., p. 95 , pl. 9 , fig. 1.

Material. - Two needles attached to the twig, outcrop (ZD RUP 61).

Description. - Although lacking epidermal features the recovered impression of a twig fragment is referred to Torreya because of needle morphology and very narrow abaxial stomatal bands. Similar needle fossils have often been recorded in the Oligocene of North Bohemia, e.g., at Žichov, Kundratice and in Saxony at Seifhennersdorf (Kvaček 1984, Walther \& Kvaček 2007). This conifer has not been documented so far in the Eocene.

Angiosperms

Family Nymphaeaceae

\section{Genus Sabrenia M. Collinson}

\section{cf. Sabrenia sp.}

Figure $3 \mathrm{~K}-\mathrm{N}$

Material. - Dispersed carbonized seeds - drill-cores RU 44, depth 39.5 m (G 9448, G 9449a, b), RU 60/94, depth 30.6-31.4 m (NM G 9431a-c).

Description. - Compressions of originally globose to ovoid seeds are variously deformed, disc-shaped, mostly rounded, ca 2-3.5 mm in diameter, rarely broadly elliptic, $2.5 \mathrm{~mm}$ wide and $3.6 \mathrm{~mm}$ long with slightly thickened peripheral rim and poorly preserved tiny embryotega (cap). The raphe ridge is obscured; surface of testa is finely granulate (granules $\mathrm{ca} 30$ $\mu \mathrm{m}$ in diameter), more distinctly in larger specimens. At places the cell structure of testa is visible showing cells $c a 60 \mu \mathrm{m}$ long and $30 \mu \mathrm{m}$ wide with more or less regularly deeply lobate-digitate anticlinal walls (usually 8-10 sinuses per cell).
The anatomical structure as far as it is preserved and gross morphology refers the material of Roudníky to seeds described in detail from the late Eocene Bembridge marls (Collinson 1980) as Sabrenia chandlerae. In the absence of further anatomical details we refrain from more accurate identification and comparisons with similar fossil seeds partly assigned to other Brasenia-like fossil taxa. Among seeds of the Nymphaeaceae $s$. $l$. recovered in the Kučlín diatomite (Kvaček \& Teodoridis 2011), some match in the size and form those from Roudníky and Bembridge, although surface details necessary for more precise identification have not been available due to poor preservation of the Kučlín material as impressions. Similar small reticulate-granulate seeds, which were described as Palaeonymphaea circumcincta (Menzel) Mai from Germany (Ringsberg, ?early Oligocene - Mai 1988), differs in finely undulating anticlinal cell walls of testa. The Oligocene records of Nymphaealean seeds assigned to Dusembaya seifhennersdorfensis (Engelhardt) Mai (Mai 1988) differ in smooth surface.

Family Lauraceae

\section{Genus Laurophyllum Göpp.}

\section{Laurophyllum acutimontanum Mai}

Figures 3O-Q, 7N

1963 Laurophyllum (Tetradenia) acutimontanum Mai, p. 72, pl. 8, figs 7-9, 12 (non 10), pl. 9, figs $1-4$, text-figs $11 \mathrm{f}-\mathrm{h}$.

Material. - Leaf compressions with epidermal anatomy, drill-cores RU 44, depth 18m (NM G 8786), RU 60, depth 27.5-28 m (NM G 9404 - RU 60-11A), outcrop (NM G 8808).

Description. - Thanks to preserved epidermal anatomy (amphicyclobrachyparacytic stomata with deeply sunken guard and inner subsidiary cells), a few lauroid compressions are assignable to this Palaeogene evergreen element. It evolved in the late Eocene (upper part of the Staré Sedlo Formation Knobloch et al. 1996, Teodoridis et al. 2012) and spread typically in the Oligocene (Walther \& Kvaček 2007).

\section{Laurophyllum pseudoprinceps Weyland \& Kilpper} Figures 3R-T, 7O, P, 8A

1963 Laurophyllum pseudoprinceps Weyland \& Kilpper, p. 100, pl. 23, figs 14-19, text-fig. 6 .

Material. - Leaf compressions with epidermal anatomy, drill-cores RU 43, depth 36-37 m (NM G 8762 - RU 43-1), 
RU 44, depth 18 m (NM G 8772 - RU 44-9a), outcrop (NM G 8809).

Description. - Lauroid leaf compressions with slightly more pronounced subbasal secondaries show diagnostic traits of Laurophyllum pseudoprinceps: bead-like thickenings of the anticlinal walls and amphibrachyparacytic stomata with broad ledges not reaching the stomatal poles (Weyland \& Kilpper 1963, Kvaček 1971). This element occurs exceptionally in the Eocene (Knobloch et al. 1996). It was widely spread in the Oligocene of Central Europe, survived to the Miocene and accompanied mainly thermophilous plant assemblages (Holý et al. 2012).

Family Magnoliaceae

\section{Genus Liriodendron L.}

\section{Liriodendron sp.}

Figure 3U, V

2009 Liriodendron haueri Ettingshausen; Akhmetiev et al., p. 95, pl. 9, fig. 8 .

Material. - Fruitlets, drill-cores RU 44, depth 18 m (NM G 8788), RU 60, depth 27.5-28 m (NM G 9418), outcrop (ZD RUP 18, 28, 63A, 91).

Description. - The recovered dispersed winged samaras typical of this genus are assigned to the same genus as the record from the Oligocene of Markvartice (Bůžek et al. 1976, as Liriodendron haueri Ettingshausen). The basal part shows occasionally pairs of finely tuberculate seeds. No co-occurring foliage referable to the same genus has been found to help a more precise specific identification, although several records are known from the Bohemian Palaeogene (Ettingshausen 1869, as Liriodendron haueri, Žichov, Knobloch 1961, as Liriodendron procaccinii Ung., Hrazený, Kvaček \& Teodoridis 2011, as Liriodendron sp., Kučlín).

Family Platanaceae

\section{Genus Platanus L.}

Platanus neptuni (Ettingshausen)

Bůžek, Holý \& Kvaček

Figures 3W-Y, 8B, C

1967 Platanus neptuni (Ettingshausen) Bůžek, Holý \& Kvaček, p. 205, pl. 1, figs 1-4, 6 (non 5 - Sloanea artocarpites), pls 2-4.
2009 Platanus neptuni (Ettingshausen) Bůžek, Holý \& Kvaček; Akhmetiev et al., p. 95, pl. 9, fig. 3.

Material. - Simple leaves, partly with epidermal anatomy, outcrop (ZD RUP12A), drill-cores RU 48, depth $49 \mathrm{~m}$ (NM G 8794 - RU 48-10), RU 60, depth 27.5-28 m (NM G 9403 - RU 60-9).

Description. - Foliage of this extinct plane tree is preserved in the material studied as impressions of dentate simple leaves and fragmentary compressions of sub-entire margined leaves with typical epidermal anatomy: deeply undulate anticlines of epidermal cells, stomata with large apertures and compound trichome bases. However, remains of infructescences have not been recovered. This deciduous element was distributed in Europe in the Palaeogene, in the Eocene more often in its trifoliate form, and reached even the Miocene (Kvaček \& Manchester 2004).

Family Cercidiphyllaceae

\section{Cercidiphyllum Siebold \& Zucc.}

\section{Cercidiphyllum crenatum (Unger) R. Brown}

Figure $3 \mathrm{~A}^{*}-\mathrm{D} *, \mathrm{~F}^{*}$

1935 Cercidiphyllum crenatum (Unger) R. Brown, p. 575, pl. 68, figs 1, 6, 8-10.

2009 Cercidiphyllum crenatum (Unger) R. Brown; Akhmetiev et al., p. 95, pl. 9, fig. 9.

2009 Daphnogene cinnamomifolia (Brongniart) Unger; Akhmetiev et al., p. 95, pl. 9, fig. 8.

Material. - Leaves, fruits, seeds, drill-cores RU 60, depth 28-28.5m (NM G 9414 - RU 60-13), outcrop (ZD RUP 18, 19, 21A, 22A, 56A, 89, 105, 134).

Description. - This element is represented by clustered follicules, dispersed winged seeds and typically dimorphous foliage: rounded cordate crenate leaves of mature branches and narrow elliptic juvenile forms recalling foliage of Ziziphus. Similar variation is known elsewhere (Kvaček \& Walther 2004, Bechlejovice). C. crenatum is common in the Oligocene to Neogene of Europe. In the Eocene only the related extinct Trochodendroides, associated with a different type of fruits (Nyssidium), occurred (e.g., in the Spitsbergen Palaeogene - Budantsev \& Golovneva 2009).

Family Hamamelidaceae

Genus Matudaea Lundell 


\section{cf. Matudaea menzelii Walther \\ Figure $3 \mathrm{E}^{*}$}

? 1978 Matudaea menzelii Walther in Mai \& Walther, p. 51, pl. 3, figs $1-4$, pl. 11, figs $2-3$, pl. 24, figs $1-9$.

Material. - Leaf impression, outcrop (ZD RUP 134).

Description. - The long petiolate entire-margined basally triveined leaf matches Matudaea menzelii known from several Oligocene sites in Germany (Walther in Mai \& Walther 1978, Walther 1999). The identification of the record is not supported by epidermal anatomy. Similar fragments, also without cuticle structure, were described from other parts of the České středohoři Mts, e.g., Bechlejovice, Kundratice and Suletice (see Kvaček \& Walther 2004).

\section{Family Fabaceae}

\section{Genus Gleditsia L.}

\section{Gleditsia sp.}

Figure 4A

Material. - Detached leaflets, outcrop (ZD RUP 52A, 109).

Description. - Some indistinctly widely toothed legume leaflets of the Roudníky flora match in form fossils ascribed to Gleditsia (e.g., Guo \& Zhou 1992).

\section{Genus Leguminosites Bowerbank emend. Schimper}

\section{Leguminosites sp.}

Figure 4B

2009 Leguminosae gen. et sp. indet.; Akhmetiev et al., p. 95 , pl. 9 , fig. 17 .

Material. - Impressions of detached leaflets, outcrop (ZD RUP 52A).
Description. - Ordinary detached leaflets of legumes are not identifiable to the natural genus and are summarized here in this artificial category. They may represent some more distinct morphotypes.

\section{Genus Palaeolobium Unger}

\section{Palaeolobium sp.}

Figure 4C, D

Material. - Impressions of detached leaflets (?), outcrop (ZD RUP 113, 135).

Description. - The foliage assigned to this taxon may not belong to legumes although it matches in gross morphology (spatulate lamina, longer stalk) with this morphotype known from other Palaeogene localities (Häring, Socka, Kundratice). The material at hand is devoid of epidermal anatomy. Similar specimens from Kundratice (Kvaček \& Walther 1998) yielded epidermal patterns unlike legumes. A more detailed study of this taxon is required to clarify its affinities.

\section{Genus Mimosites Bowerbank emend. Ettingshausen}

\section{Mimosites haeringianus Ettingshausen}

Figure 4E

1853 Mimosites haeringianus Ettingshausen, p. 92, pl. 30, figs 23-37 ("haeringiana”).

2009 Mimosites haeringianus Ettingshausen; Akhmetiev et al., p. 95, pl. 9, fig. 21.

Material. - Detached leaflets, outcrop (ZD RUP 13), drillcore RU 60 (unnumbered).

Description. - Narrow linear blunt leaflets with a characteristic asymmetrical base and venation do not differ from other records of this legume typical of the Palaeogene (for detailed discussion see Kvaček \& Walther 1998).

Figure 4. Locality Roudníky. • A - Gleditsia sp., leaflet, ZD RUP 109. • B - Leguminosites sp., leaflet, ZD RUP 52A. • C - Palaeolobium sp., leaf, ZD RUP 113.・D - Palaeolobium sp., leaf, ZD RUP 135. E - Mimosites haeringianus Ettingshausen, part of leaf disintegrated into leaflets, ZD RUP 13. - F - ?Castaneophyllum lonchitiforme Kvaček \& Walther, leaf apex, ZD RUP 107. • G - Alnus gaudinii (Heer) E. Knobloch \& Kvaček, leaf fragment, NM G 9407a. • H - Alnus kefersteinii (Göppert) Unger, two female infructescences on a common stalk, ZD RUP 21a. • I - Alnus kefersteinii (Göppert) Unger, two male catkins, ZD RUP 16. • J - Alnus gaudinii (Heer) E. Knobloch \& Kvaček, leaf impression, ZD RUP 131. • K - Alnus gaudinii (Heer) E. Knobloch \& Kvaček, leaf base, ZD RUP 130. • L - Alnus gaudinii (Heer) E. Knobloch \& Kvaček, leaf compression, NM G 8798a, RU 48-16. • M - Betula dryadum Brongniart, catkin, ZD RUP 147. • N - Betula dryadum Brongniart, winged fruitlet, ZD RUP 78. • O - Betula alboides Engelhardt emend. Walther \& Kvaček, leaf impression, ZD RUP 148. • P - Betula alboides Engelhardt emend. Walther \& Kvaček, leaf impression, ZD RUP 150. • Q - Carpinus mediomontana Mai, involucre, ZD RUP 14a. $・ \mathrm{R}$ - Carpinus mediomontana Mai, involucre, ZD RUP 58a. $・ \mathrm{~S}-$ Carpinus sp., leaf apex, NM G 8766, RU 44. • T - Ostrya atlantidis Unger, leaf compression, NM G 9442, RU 48. • U - Carpinus sp., leaf, ZD RUP 104. • V - Ostrya atlantidis Unger, leaf base, NM G 9425, RU 60-17. Scale bars: A-M, O, Q-V = $5 \mathrm{~mm} ; \mathrm{N}=1 \mathrm{~mm} ; \mathrm{P}=10 \mathrm{~mm}$. 
Zlatko Kvaček et al. • Eocene-Oligocene transition in North Bohemia
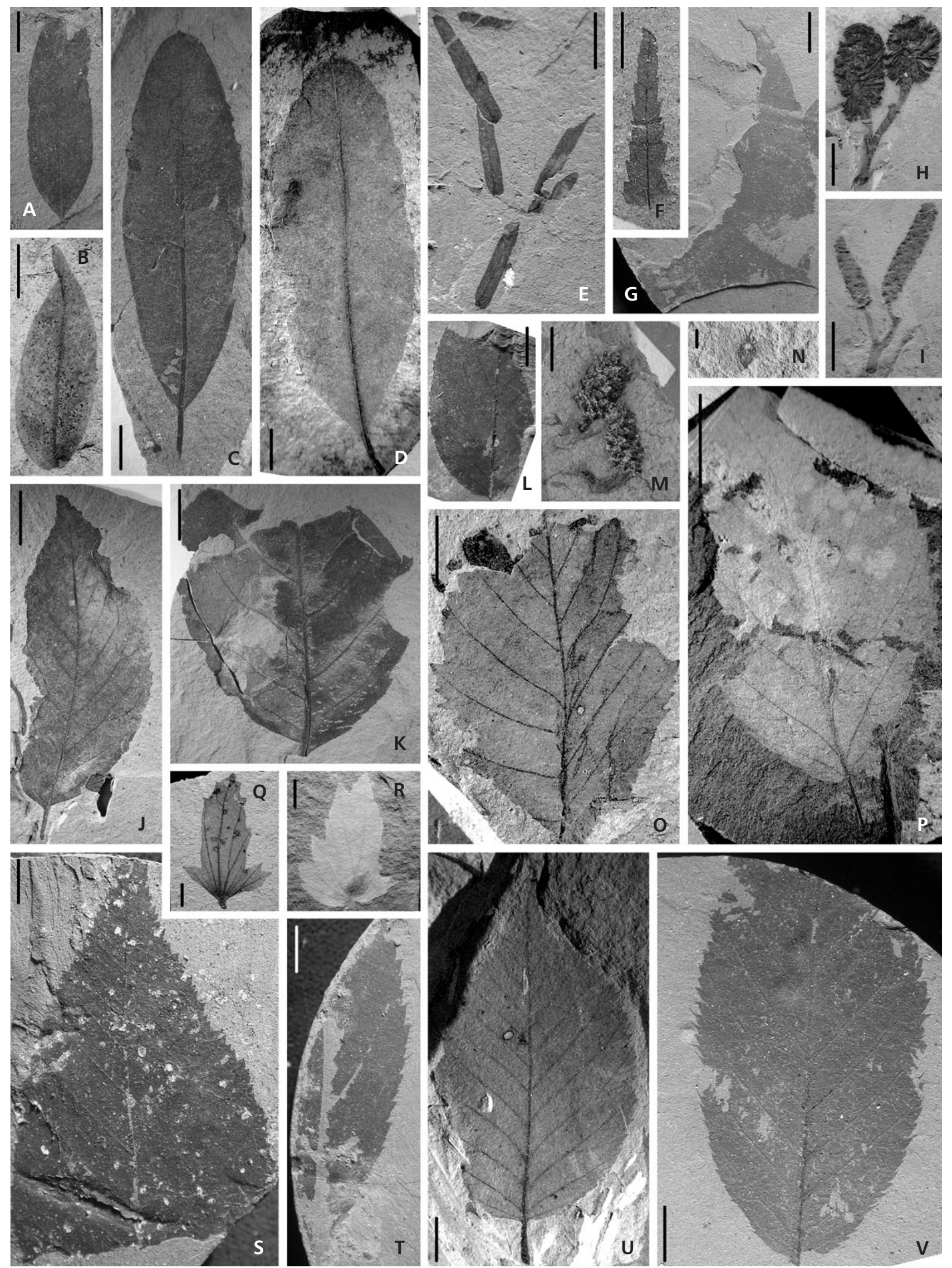
Family Fagaceae

\section{Genus Castaneophyllum Dilcher \& Jones}

\section{? Castaneophyllum lonchitiforme Kvaček \& Walther \\ Figure 4F}

?2012 Castaneophyllum lonchitiforme Kvaček \& Walther, p. 251 , pl. 3 , figs $1-5,8-10$, pl. 4 , figs $1-6$, pl. 6 , figs $1-6$.

Material. - Outcrop (ZD RUP 107).

Description. - A single leaf apex recalls in slender form and simple dentate margin oak-like foliage previously assigned to Quercus lonchitis Unger and occurring mainly in the Oligocene of Seifhennersdorf, Suletice, Lochočice and Stadice (Walther \& Kvaček 2007). More detailed comparisons of the compression material from the above mentioned sites revealed morphological differences to the type specimens from the late Eocene locality Socka and epidermal features leading to the Castaneoideae (Kvaček \& Walther 2012). The specimen at hand does not show any cuticle structure.

Family Betulaceae

\section{Genus Alnus Mill.}

\section{Alnus gaudinii (Heer) E. Knobloch \& Kvaček}

Figures 4G, J-L, 8D

1976 Alnus gaudinii (Heer) E. Knobloch \& Kvaček, p. 33, pl. 6, figs 1, 3, pl. 7, figs 1,5 , pl. 13, fig. 4, pl. 15, figs $1-4,7,8,10,11,13,15,17$, pl. 16, figs $1-5$, pl. 19, fig. 15 , pl. 20 , fig. 10 , text-figs 11,12 .

Material. - Leaves, outcrop (ZD RUP 130, 131, 149), drill-cores RU 43, depth 116.3 m (NM G 8776, G 8792 RU 43-2), RU 48, depth 49 m (NM G 8793 - RU 48-11, NM G 8797 - RU 48-13, NM G 8798 - RU 48-16), RU 60, depth 27.5-28 m (NM G 8812, G 9407a, G 9409 RU 60-4).

Description. - Several ovate finely bluntly serrate long petiolate leaves with cuneate bases belong to alder foliage and match in morphological details and party even in epidermal anatomy (large stomata of the laterocytic type) to the other records of Alnus gaudinii from the České středohoří Mts (Kundratice - Kvaček \& Walther 1998, Bechlejovice - Kvaček \& Walther 2004) and Saxony (Seifhennersdorf - Walther \& Kvaček 2007). Similar leaf impressions differing in rounded bases were assigned also to Alnus pho- caeensis Saporta (Seifhennersdorf - Mai 1963, Kleinsaubernitz - Walther 1999).

\section{Alnus kefersteinii (Göppert) Unger}

Figure 4H, I

1847 Alnus kefersteinii (Göppert) Unger, p. 113, pro parte, pl. 33, fig. 2 (non pl. 33, figs 1, 3-4).

Material. - Infructescence, outcrop (ZD RUP 21, 85a), male catkin, outcrop (ZD RUP 16).

Description. - These infructescences and inflorescences belong obviously to the above foliage and accompany A. gaudinii in several other sites (e.g., Kundratice - Kvaček \& Walther 1998).

\section{Genus Betula L.}

Betula alboides Engelhardt emend. Walther \& Kvaček Figure $4 \mathrm{O}, \mathrm{P}$

2007 Betula alboides Engelhardt emend. Walther \& Kvaček, p. 103, pl. 9, figs 2-7, text-fig. 5b.

Material. - Leaves, outcrop (ZD RUP 145, 146, 148).

Description. - Birch foliage occurring in the outcrop of Roundíky compares well with the records from Seifhennersdorf (Walther \& Kvaček 2007) and Kundratice (Kvaček \& Walther 1998), the latter assigned to Betula buzekii Kvaček \& Walther, which was reduces into synonyms for priority reasons.

\section{Betula dryadum Brongniart}

Figure 4M, N

1828 Betula dryadum Brongniart, p. 49, pl. 3, fig. 5.

Material. - Fruitlet, outcrop (ZD RUP 78), male catkin (ZD RUP 147).

Description. - The double winged fruitlet at hand confirms other remains of this kind occurring in Saxony (Mai 1963, Walther \& Kvaček 2007) and but rarely in the České středohoří Mts (Kvaček \& Walther 1998, as Betula sp.). The associated male catkin belongs obviously to the same plant. Foliage of the same plant described above accompanies these fruit remains at most localities. 


\section{Genus Carpinus L.}

\section{Carpinus mediomontana Mai}

Figure 4Q, R

1978 Carpinus mediomontana Mai in Mai \& Walther, p. 68, pl. 6, figs 6a-c, d (holotype), e-g, pl. 28, figs 21-27.

2009 Carpinus mediomontana Mai; Akhmetiev et al., p. 95 , pl. 9 , fig. 6 .

Material. - Involucres, drill-core RU 60, depth 27.5-28 m (NM G 8811), outcrop (ZD RUP 14A, 58A, $99,100,101)$.

Description. - Well preserved involucres of hornbeam show variations in morphology of this plant common in the Oligocene of North Bohemia and Saxony but so far lacking in the Eocene (for discussion of the taxonomy see Walther \& Kvaček 2007).

\section{Carpinus sp.}

Figure 4S, U

Material. - Leaves, drill-cores RU 44, depth 52 m (NM G 8795, G 8766), RU 48, depth 51 m (NM G 9438, 9441), RU 60, depth 27.5-28 m (NM G 9414c, G 9426, 9436), outcrop (ZD RUP 98, 102, 103, 104, 106, 111, 114, 119).

Description. - Various leaf fossils recovered in the Roudníky flora show affinities to foliage usually ascribed to Carpinus grandis Ung. As stated by Walther \& Kvaček (2007) this morphotaxon may correspond to more species and in our case it surely belongs to the associated fruit remains described below.

\section{Genus Ostrya Scop.}

\section{Ostrya atlantidis Unger}

Figures 4T, V, 5A, B

1850 Ostrya atlantidis Unger, p. 408.

2009 Ostrya atlantidis Unger; Akhmetiev et al., p. 95, pl. 9, figs 11-12.

Material. - Leaf impressions, drill-cores RU 43, depth 116.3 (NM G 8784), RU 44, depth 18 m (NM G 8763, G 8765, G 8766,G 8789a, G 8802), RU 45a, depth 44-45 m (NM G 8778a, G 9444c), RU 48, depth 50 m (NM G 9442), RU 60, depth 27.5-28 m (NM G 8760a, G 9410 - RU 60-8, G 9425 - RU 60-17), outcrop, fruit bracts, drill-core
RU 60, depth 27.5-28 m (NM G 8832), outcrop (ZD RUP 15A, 32, 33, 124, 125, 126).

Description. - Both fruits, partly only bracts enveloping the fruits and foliage typically double serrate mucronate at margin occur in all sites at Roudníky. The record well corresponds to others from Saxony (Seifhennersdorf - Walther \& Kvaček 2007) and North Bohemia (Kundratice, Bechlejovice - Kvaček \& Walther 1998, 2004).

Family Juglandaceae

\section{Genus Carya Nutt.}

Carya fragiliformis (Sternberg) Kvaček \& Walther in Walther \& Kvaček

Figure 5C, D

2007 Carya fragiliformis (Sternberg) Kvaček \& Walther in Walther \& Kvaček, p. 110, pl. 11, figs 1-3, pl. 23, figs $8-10$, text-fig. $6 \mathrm{~b}$.

2009 Carya fragiliformis (Sternberg) Kvaček \& Walther; Akhmetiev et al., p. 95, pl. 9, fig. 10.

Material. - Leaflets, drill-cores RU 48, depth $48 \mathrm{~m}$ (NM G 8796 - RU 48-7), RU 60, depth 28.0-28.5 m (NM G 9414b), outcrop (ZD RUP 51, 128).

Description. - The juglandaceous foliage from the Roudníky area is somewhat arbitrarily assigned either to Carya or Cyclocarya according to the leaflet morphology as characterized by Walther \& Kvaček (2007). The accompanying fruits or any details of epidermal structure are not available in the Roudníky flora. The present records are similar to those recovered at many sites of Oligocene age in North Bohemia and Saxony (Bůžek et al. 1976; Kvaček \& Walther 1998, 2004; Walther \& Kvaček 2007). Only scanty and equivocal remains similar to Carya leaflets have been recorded also in the late Eocene diatomites of Kučlín (Kvaček \& Teodoridis 2011).

\section{Genus Cyclocarya Iljinskaya}

\section{Cyclocarya sp.}

Figure 5E, F

2009 Cyclocarya sp.; Akhmetiev et al., p. 95, pl. 9, fig. 18.

Material. - Leaflets, outcrop (ZD RUP 48, 127).

Description. - See above under Carya fragiliformis for comments. 
Family Rhamnaceae

\section{Genus Ziziphus Miller}

\section{Ziziphus ziziphoides (Unger) Weyland}

Figure 5G

1943 Ziziphus ziziphoides (Unger) Weyland, p. 113.

Material. - Leaf impression, outcrop (ZD RUP 81).

Description. - A single leaf impression recovered in the outcrop of Roudníky belongs according to gross morphology (basally triveined blade with entire base and very finely serrate apex) to Ziziphus foliage as known from the European late Eocene (Bembridge - Reid \& Chandler 1926, Kučlín Bůžek et al. 1990, Kvaček \& Teodoridis 2011) and Oligocene floras (for distribution see Mai 1995, p. 275, for taxonomical treatment Kvaček \& Walther 2004). Broader morphotypes occurring in the Kučlín and Bechlejovice diatomites were separated as Ziziphus ziziphoides forma bilinica (Ettingshausen) Kvaček \& Walther (2004).

\section{Family Rosaceae}

\section{Genus Rosa L.}

\section{Rosa milosii Kvaček \& Walther}

Figure 5H, J, K

2004 Rosa milosii Kvaček \& Walther, p. 38, pl. 17, figs 4-8.

2009 Rosa milosii Kvaček \& Walther; Akhmetiev et al., p. 95, pl. 9, fig. 15.

Material. - Fruits, partly attached to thorny twigs and isolated twigs, drill-core RU 48: depth 48 m (G 9440a, b), outcrop (ZD RUP 35, 36A, 37, 83a).

Description. - Abundant fruits ("rose hips") partly attached to thorny twigs or isolated thorny twigs (Fig. 5H) occur in the Roudníky area and correspond well with the record from Bechlejovice (Kvaček \& Walther 2004).

\section{Rosa lignitum Heer}

Figures 5L, M, 8E

1869 Rosa lignitum Heer, p. 99, pl. 30, fig. 33.

Material. - Leaflets, drill-cores RU 44, depth $18 \mathrm{~m}$ (NM G 8771 - RU 44-3), RU 48, depth 51 m (NM G 8781 RU 48-3, G 9440), RU 60, depth 51.75 m (NM G 8761, G 9424a - RU 69-18), outcrop (ZD RUP 38, 39, 40, 41A, 42, 46).

Description. - The foliage belonging to the above discussed fruits fits into the concept of a morphotype called Rosa lignitum Heer, and even corresponds in leaf epidermal anatomy: anomocytic stomata with slightly thickened ledges forming a lanceolate aperture. A similar structure was found in the record from Haselbach (Walther in Mai \& Walther 1978).

\section{Genus Pyracantha M. Roem.}

\section{Pyracantha kraeuselii Walther}

Figures 5O-P, 8F, G

1978 Pyracantha kraeuselii Walther in Mai \& Walther, p. 98 , pl. 7 , fig. 11 , pl. 11 , fig. 4 , pl. 35 , figs $7-9$, pl. 39, figs $1-7$.

Material. - Leaves with epidermal structure, drill-cores RU 43 m, depth 36-37 m (G 8767 b - RU 43-3B), RU 60, depth 27.5-28 m (NM G 9405 - RU 60-3, G 9415 RU 60-6, G 9432 - RU 60-16).

Description. - This not easily recognizable element is characteristic by tough narrow subentire-margined leaves with anomocytic (?) round-oval stomata showing thickened

Figure 5. Locality Roudníky. • A - Ostrya atlantidis Unger, leaf base, ZD RUP 33. - B - Ostrya atlantidis Unger, fruit bract enveloping fruit, ZD RUP 32. $・$ C - Carya fragiliformis (Sternberg) Kvaček \& Walther, fragmentary leaflet, ZD RUP 128. $\bullet$ D - Carya fragiliformis (Sternberg) Kvaček \& Walther, leaflet apex, NM G 8796, RU 48-7.•E-Cyclocarya sp., leaflet, ZD RUP 127. •F-Cyclocarya sp., leaf, ZD RUP 48. G -Ziziphus ziziphoides (Unger) Weyland, leaf, ZD RUP 49. $・ \mathrm{H}-$ Rosa milosii Kvaček \& Walther, thorny twig, ZD RUP 38. ・ I - cf. Dicotylophyllum ungeri (Engelhardt) Walther \& Kvaček, leaf, NM G 8805, RU 43. • J - Rosa milosii Kvaček \& Walther, fruit, ZD RUP 36a. K - Rosa milosii Kvaček \& Walther, fruit, ZD RU 37. $\bullet$ L - Rosa lignitum Heer, leaflet, ZD RUP 41a. $\bullet$ M - Rosa lignitum Heer, leaflet, ZD RUP 92a. • N - Rosa lignitum Heer, leaflet, ZD RUP 108. - O - Pyracantha kraeuselii Walther in Mai \& Walther, fragmentary leaf compression with cuticle, NM G9405a. $\bullet$ P - Pyracantha kraeuselii Walther in Mai \& Walther, leaf compression with cuticle, NM G8767b, RU 43-38. • Q - cf. "Viburnum" atlanticum Ettingshausen, leaf compression with cuticle, NM G 9439a. $\bullet$ R - Crataegus pirskenbergensis E. Knobloch, fragmentary leaf impression, ZD RUP 120. $\bullet$ S Crataegus pirskenbergensis E. Knobloch, leaf impression, ZD RUP 11. T - Crataegus pirskenbergensis E. Knobloch, base of larger leaf, ZD RUP 129. •U - Ulmus sp., fruit, ZD RUP 25. $・$ V - cf. Ulmus sp., fruit, ZD RUP 26. - W - Ulmus fischeri Heer, small leaf impression, ZD RUP 132. X - Ulmus fischeri Heer, leaf fragment, NM G 8764, RU 48. $• \mathrm{Y}-$ Ulmus fischeri Heer, leaf impression, ZD RUP 34. Scale bars: A, C-L, S, T, Y = $10 \mathrm{~mm}$; A-J, M-R, U-X $=5 \mathrm{~mm}$. 


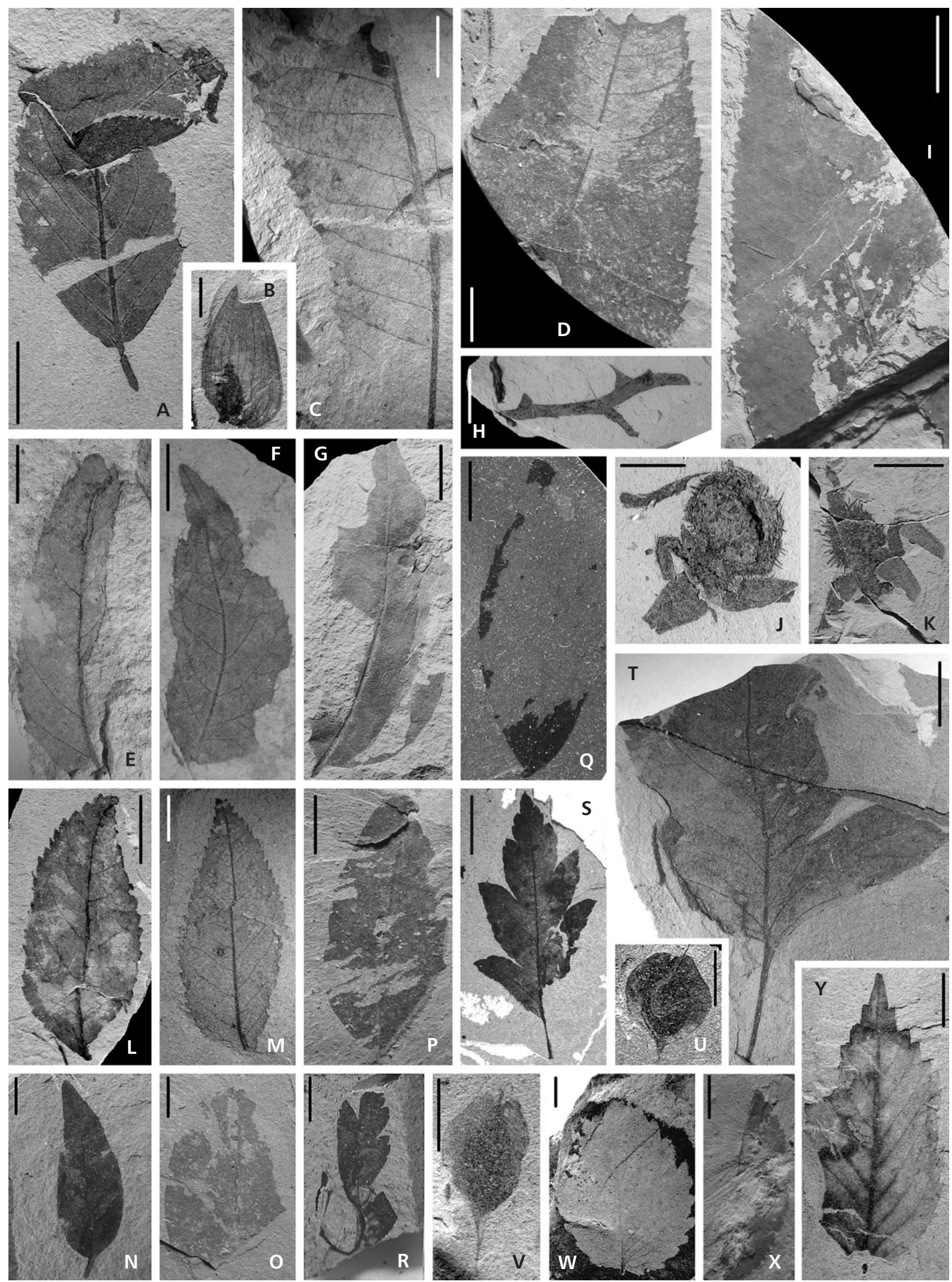


stomatal ledges reaching the poles. Besides the type locality Haselbach (Walther in Mai \& Walther 1978) this is the second record of this species. Similar leaf remains from the Oligocene of Flörsheim have been recorded as Andromediphyllum Kvaček (2004a) but they clearly differ in circular stomata.

\section{Genus Crataegus L.}

\section{Crataegus pirskenbergensis E. Knobloch} Figure 5R-T

1961 Crataegus pirskenbergensis E. Knobloch, p. 26, pl. 7, figs $2-5$.

2009 Crataegus pirskenbergensis E. Knobloch; Akhmetiev et al., p. 95, pl. 9, fig. 13.

Material. - Leaves, drill-core RU 44, depth 18 m (NM G 8785a - RU 44-4A), outcrop (ZD RUP 11, 120, 129).

Description. - Leaves of this Crataegus are recognized on the basis of pinnately sected to pinnately lobed lamina divided into triangular finely toothed lobes in 3 pairs diminishing in size from the base towards the apex. Such morphotypes occur in the Oligocene at the type locality Hrazený (Knobloch 1961) and Bechlejovice (Kvaček \& Walther 2004).

\section{?Rosaceae gen.}

\section{cf. Dicotylophyllum ungeri (Engelhardt) Walther \& Kvaček \\ Figure 5I}

? 2007 Dicotylophyllum ungeri (Engelhardt) Walther \& Kvaček, p. 116, pl. 15, figs 5-7.

Material. - Leaves, drill-cores RU 43, depth 114 m (NM G 8805), RU 44, depth 16 m (NM G 8806).

Description. - Some narrow elliptic leaf remains recalling Betulaceae or Juglandaceae differ in regularly bluntly simple serrate margin. Similar morphotypes of foliage from Seifhennersdorf and Bechlejovice were tentatively compared with the Rosaceae (Kvaček \& Walther 2004, as Rosaceae gen. et sp. 2 and Rosaceae gen. et sp. 4, Walther \& Kvaček 2007, as Dicotylophyllum ungeri).

\section{Family Ulmaceae}

\section{Genus Ulmus L.}

\section{Ulmus fischeri Heer}

Figure 5W-Y

1856 Ulmus fischeri Heer, p. 57, pl. 57, figs 1-3.

2009 Ulmus fischeri Heer; Akhmetiev et al., p. 95, pl. 9, fig. 20.

Material. - Leaf impressions, outcrop (ZD RUP 34, 132).

Description. - Coarsely double dentate leaf impressions with typical ulmoid venation occur rarely in outcrops of Roudníky. They correspond to the species identified as Ulmus fischeri commonly recorded in the Oligocene of North Bohemia and Germany (see Kvaček \& Walther 2004).

\section{Ulmus sp.}

Figure 5U, V

Material. - Fruits, outcrop (ZD RUP 25, 26).

Description. - The bicornate winged elm samaras from Roudníky correspond in small size and basal position of the large nutlet with fruits accompanying the above foliage also at Kundratice (Kvaček \& Walther 1998) and Bechlejovice (Kvaček \& Walther 2004). The specimens are not well preserved and identification is partly equivocal (Fig. 5V). This fruit material is the first record from the Eocene of this region.

\section{Genus Zelkova Spach}

\section{Zelkova zelkovifolia (Unger) Bůžek \& Kotlaba} Figure 6A, B

1963 Zelkova zelkovifolia (Unger) Bůžek \& Kotlaba in Kotlaba, p. 59, pl. 3, figs 7, 8 .

2009 Zelkova zelkovifolia (Unger) Bůžek \& Kotlaba; Akhmetiev et al., p. 95, pl. 9, fig. 14.

Material. - Leaves, drill-cores RU 43, depth 37-38 m (NM G 8800), RU 44, depth 18 m (NM G 8768b), RU 48, depth 52 m (NM G 8773 - RU 48-14,), RU 60, depth 28-28.5 m (NM G 9424b, G 9435), outcrop (ZD RUP 8, 170).

Description. - Coarsely simple dentate leaf impressions at hand represent typical large specimens of Zelkova as known from the lower position of mature foliage shoots of extant species. Smaller morphotypes conforming to fruiting branches are rare in the Roudníky flora. The record of Roundíky is the oldest so far known in Europe. It 
is most comparable with that from Bechlejovice (Kvaček \& Walther 2004). Zelkova is quite rare elsewhere in the Oligocene of Central Europe (Kvaček \& Walther 1998).

Family Malvaceae

Tilia L.

Tilia brassicoides (Saporta) Kvaček \& Walther Figure $3 Z$

2004 Tilia brassicoides (Saporta) Kvaček \& Walther, p. 40, pl. 21, figs 4-7, text-fig. 11.11 .

Material. - A single bract, outcrop (ZD RUP 133).

Description. - A deeply cordate entire-margined bract, with several asymmetrically disposed basal veins, matches similar fossils assigned to Tilia brassicoides from Bechlejovice (Kvaček \& Walther 2004). The only other known record is from the French Oligocene at Manosque (Saporta 1890, as Rumex brassicoides). Corresponding foliage does not co-occur at Roudníky, but is well known from other sites (Bechlejovice, Suletice, Kundratice, Žichov, Seifhennersdorf - Kvaček \& Walther 2004).

\section{Genus Craigia W.W. Smith \& W.E. Evans}

Craigia bronnii (Unger) Kvaček, Bůžek \& Manchester Figure 6C, D

1991 Craigia bronnii (Unger) Kvaček, Bůžek \& Manchester, p. 522.

2009 Craigia bronnii (Unger) Kvaček, Bůžek \& Manchester; Akhmetiev et al., p. 95, pl. 9, fig. 7.

Material. - Capsule valves, drill-cores RU 48, depth 50 m (NM G 8764b, c), RU 60, depth 60 m (NM G 9413b, G 9414d, G 9419a, b, G 9420b, d, G 9437a, b), outcrop (ZD RUP 29, 30, 31, 420).

Description. - Several impressions of rounded and broadly oval capsule valves of Craigia fruits with characteristic venation radiating from the medial fusiform locule are represented in the studied outcrop and core material by well preserved specimens. These valves, like at Bechlejovice (Kvaček \& Walther 2004), are usually smaller than those from the Miocene populations (Kvaček 2004b). This species has not been identified so far from the Eocene in central Europe.

\section{Genus Dombeyopsis Unger}

Dombeyopsis lobata Unger

Figure 6E

1850 Dombeyopsis lobata Unger, p. 447.

Material. - Leaf impressions, outcrop (ZD RUP 29, 30).

Description. - As in other occurrences of this plant, also at Roudníky, trilobate entire-margined foliage of the Dombeyopsis lobata type accompanies the above described Craigia bronnii fruit remains and obviously belongs to the same plant. The fruits are smaller than in the Miocene populations (e.g., the Bílina Mine - Kvaček 2004b) and match the records at Bechlejovice (Kvaček \& Walther 2004).

Family Anacardiaceae

\section{Genus Toxicodendron Mill.}

\section{Toxicodendron herthae (Unger) Kvaček \& Walther} Figure 6F

1998 Toxicodendron herthae (Unger) Kvaček \& Walther, p. 27 , pl. 15 , figs $3-8$, text-fig. 13.16 .

Material. - Leaflet, outcrop (ZD RUP 126).

Description. - The single simple bluntly serrate leaflet conforms with the ordinary morphotypes of this species as known from the early Miocene and Oligocene sites (see Kvaček \& Walther 1998), which are quite variable according to the position in compound leaves. Records older than early Oligocene are not known so far.

Family Sapindaceae

\section{Genus Acer L.}

Acer angustilobum Heer

Figure $6 \mathrm{G}, \mathrm{H}$

1859 Acer angustilobum Heer, p. 57, pl. 117, fig. 25a, pl. 118, figs 4-9.

2009 Acer angustilobum Heer; Akhmetiev et al., p. 95, pl. 9 , fig. 2.

Material. - Leaves, drill-cores RU 44, depth 16 m (NM G 8791 - RU 44-12), RU 48, depth 51 m (NM G 9774, RU 48-9), outcrop (ZD RUP 44). 
Description. - Maple leaves assigned to Acer angustilobum Heer morphologically match abundant records of this species from Kundratice (Kvaček \& Walther 1998). In two cases, the epidermal structure has been obtained showing dense papillae on the abaxial side.

\section{Acer palaeosaccharium Stur}

Figure 6I

1867 Acer palaeosaccharinum Stur, p. 177, pl. 5, fig. 8.

Material. - Leaf, drill-core 48, depth 51 m (NM G 8774a RU 48-9), outcrop (ZD RUP 62).

Description. - Incomplete foliage at hand fits into the variation of Acer palaeosaccharinum, as known from the flora of Bechlejovice (Kvaček \& Walther 2004).

\section{Acer cf. tricuspidatum Bronn \\ Figure 6J}

? 1838 Acer tricuspidatum Bronn, p. 865, pl. 35, figs 10a, b.

Material. - Leaf impressions, outcrop (ZD RUP 34, 53).

Description. - Some impressions of maple foliage recall in broader and irregularly dentate lobes Acer tricuspidatum Bronn, as known from the monograph by Walther (1972). Epidermal structure to support this suggestion has not been obtained from the impression material. Similar morphotypes were often recorded in the Oligocene of North Bohemia and Saxony (Walther \& Kvaček 2007).

\section{Acer sp.}

Figure 6K-M

Material. - Fruits, flower, drill-cores RU 44, depth 16 m (NM G 8791 - RU 44-12), RU 45a, depth 44-45 m (NM
G 9443a, b), RU 60, depth 30.6-31.4 m (NM G 9429 RU 60-19), outcrop (ZD RUP 53, 54).

Description. - No attempt is made to assign the reproductive material to the above described leaf taxa.

Family Cornaceae

Genus Nyssa Gronov. ex L.

\section{Nyssa disseminata (Ludwig) Kirchheimer}

Figure 6N

1937 Nyssa disseminata (Ludwig) Kirchheimer, p. 916.

Material. - Endocarp compression, outcrop (ZD RUP 23).

Description. - The single available endocarp fits within the variation of Nyssa disseminata known from Seifhennersdorf (Mai 1963). Such fossils are rare in the Palaeogene of North Bohemia (e.g., at Markvartice - Bůžek et al. 1976).

Family Ebenaceae

\section{Genus Diospyros L.}

Diospyros sp.

Figure 60

Material. - Calyx, outcrop (ZD RUP 77a).

Description. - The single calyx impression referable to Diospyros does not differ from other findings of this sort from the Oligocene identified as Diospyros brachysepala A. Braun (see Walther \& Kvaček 2007). However, it differs pronouncedly from smaller morphotypes abundant in the late Eocene diatomite of Kučlín and assigned with hesitation to Diospyros (Kvaček \& Teodoridis 2011, as Diospyros? microcalyx).

Figure 6. Locality Roudníky. • A - Zelkova zelkovifolia (Unger) Bůžek \& Kotlaba, petiolate leaf impression, ZD RUP 8. • B - Zelkova zelkovifolia (Unger) Bůžek \& Kotlaba, slender petiolate leaf, ZD RUP 17a. • C - Craigia bronnii (Unger) Kvaček, Bůžek \& Manchester, capsule valve, ZD RUP 30. - D - Craigia bronnii (Unger) Kvaček, Bůžek \& Manchester, capsule valve, ZD RUP 31. E - Dombeyopsis lobata Unger, incomplete leaf base, ZD RUP 57a. • F-Toxicodendron herthae (Unger) Kvaček \& Walther, leaflet, ZD RUP 126. • G-Acer angustilobum Heer, leaf impression, ZD RUP 44. $\cdot \mathrm{H}$ - Acer angustilobum Heer, leaf compression, NM G 8791. • I - Acer palaeosaccharium Stur, leaf, NM G 8774a, RU 48-9. • J - Acer cf. tricuspidatum Bronn, leaf impression, ZD RUP 34. $\bullet$ K - Acer sp., samara, ZD RUP 53. $\bullet$ L Acer sp., samara, ZD RUP 54. $・$ M - Acer sp., flower, ZD RUP 55. $\bullet \mathrm{N}$ - Nyssa disseminata (Ludwig) Kirchheimer, impression of fruit endocarp, ZD RUP 23. $\bullet$ O - Diospyros sp., calyx, ZD RUP 77a. $\bullet$ P - Fraxinus sp., fruit base, ZD RUP 143. $\bullet$ Q - Fraxinus sp., fruit with incomplete wing, ZD RUP 144. $\bullet$ R - Fraxinus sp., winged fruit base, ZD RUP 122 . $\bullet$ S Symplocos oligocaenica Kvaček, leaf compression with cuticle, NM G 9408a, RU 60-12. • T - Carpolithes sp., enigmatic fruit remain on stalk, ZD RUP 84a. - U - Pungiphyllum cruciatum (A. Braun) Frankenhäuser \& Wilde, impression of lobed leaf fragment, ZD RUP 97. Scale bars: A, B, E-J = 10 mm; $\mathrm{C}, \mathrm{D}, \mathrm{K}, \mathrm{L}, \mathrm{N}-\mathrm{U}=5 \mathrm{~mm} ; 13=1 \mathrm{~mm}$ 
Zlatko Kvaček et al. • Eocene-Oligocene transition in North Bohemia
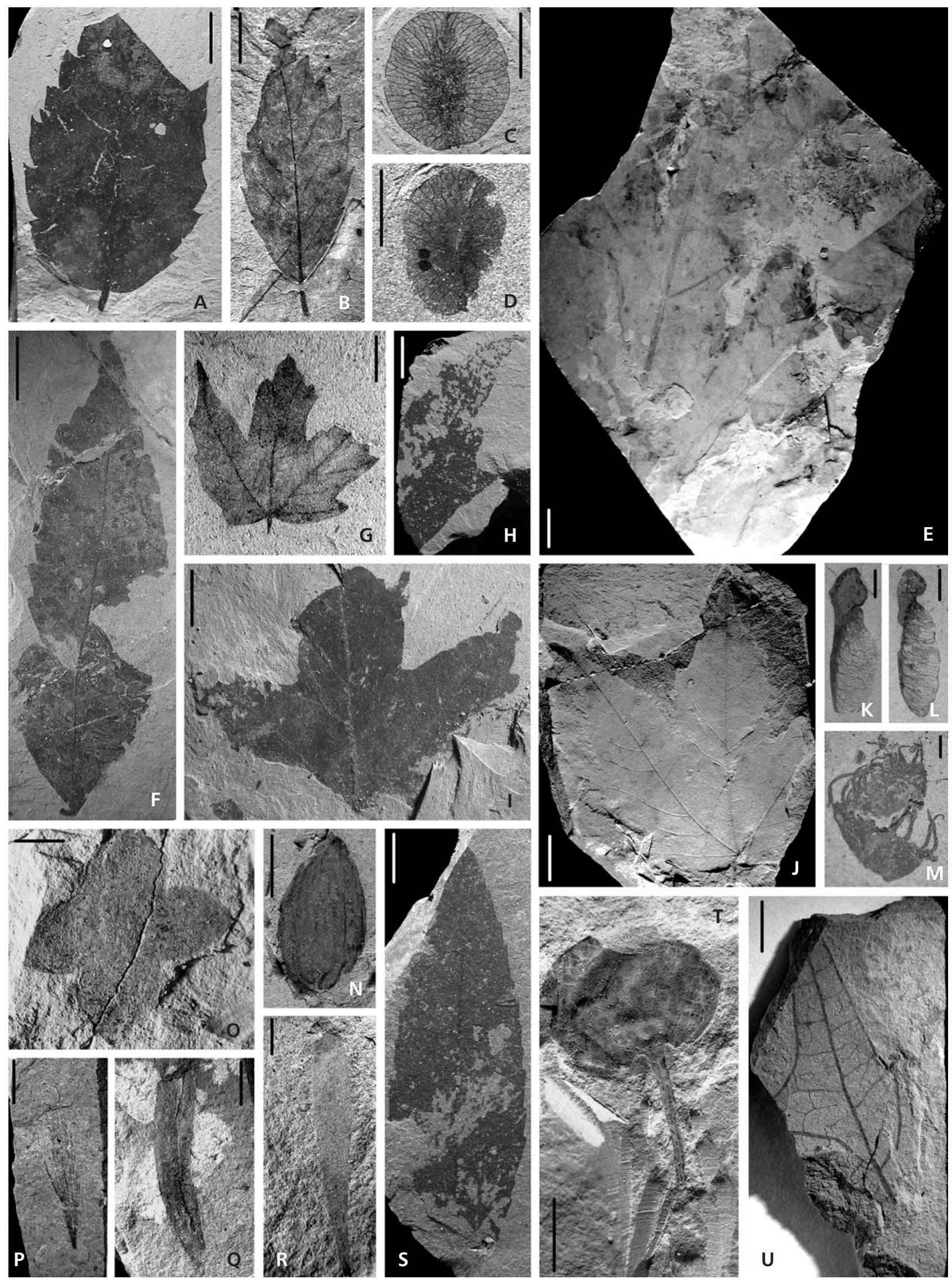
Family Symplocaceae

\section{Genus Symplocos Jacq.}

\section{Symplocos oligocaenica Kvaček}

Figures 6S, 8H, I

2004a Symplocos oligocaenica Kvaček, p. 17, pl. 14, figs 1, $10-12$.

Material. - Leaf compression with epidermal anatomy, drill-core RU 60, depth 27.5-28 m (NM G 9408 RU 60-12).

Description. - Fragmentary widely crenulate-toothed leaf compression is referred to Symplocos on account of brachyparacytic stomata in the abaxial cuticle. The reduced size of non-modified cells with almost straight anticlinal walls in comparison with stomata leads to the identification with the recently described $S$. oligocaenica Kvaček from the early Oligocene flora of Flörsheim (Kvaček 2004a). S. volkeri Kvaček from the same site neatly differs by still much smaller non-modified cells in comparison with stomata. Dicotylophyllum deichmuelleri Kvaček \& Walther (1998) from the late Eocene and early Oligocene of the České středohoří Mts (Roudníky, Kundratice, Bechlejovice - see below) belongs also to this group of Symplocos-like foliage.

\section{Family Oleaceae}

\section{Genus Fraxinus L.}

\section{Fraxinus sp.}

Figure 6P-R

Material. - Winged fruits, outcrop (ZD RUP 143, 149).

Description. - Fragmentary winged samaras with the basal seed-containing part usually aborted are recognizable in the sub-parallel venation of the wing. These coincide with other similar records (Kundratice - Kvaček \& Walther 1998, as Fraxinus sp.). The corresponding foliage has not been recovered at Roudníky yet.

Angiosperms fam. inc.

\section{Genus Carpolithes Sternberg}

\section{Carpolithes sp.}

Figure 6T

Material. - Fruit impression, outcrop (ZD RUP 84a).

Description. - An enigmatic fruit impression on stalk is strange to us and does not show much of the internal structure. Its affinities remain open for further comments.

\section{Genus Pungiphyllum Frankenhäuser \& Wilde}

Pungiphyllum cruciatum (A. Braun)

Frankenhäuser \& Wilde

Figures 6U, 7A, B

1995 Pungiphyllum cruciatum (A. Braun) Frankenhäuser \& Wilde, p. 101.

2009 Pungiphyllum cruciatum (A. Braun) Frankenhäuser \& Wilde; Akhmetiev et al., p. 95, pl. 9, fig. 19.

Material. - Leaves, outcrop (ZD RUP 60, 96, 97).

Description. - Several leaf impressions are assigned to this morphotype on account of deeply lobed lamina with spiny lobes on margin. Individual populations of this enigmatic plant vary in leaf shape from small shallow lobed forms of the middle Eocene (Pungiphyllum waltheri Frankenhäuser \& Wilde 1995 from Messel) to shallow lobed elongate forms of the late Eocene diatomites from Kučlín [Pungiphyllum heerii (Sieber) Kvaček \& Teodoridis, 2011] to the typically variable foliage distributed in the Oligocene to

Figure 7. Locality Roudníky. • A - Pungiphyllum cruciatum (A. Braun) Frankenhäuser \& Wilde, incomplete impression of lobed leaf, ZD RUP 17a. - B - Pungiphyllum cruciatum (A. Braun) Frankenhäuser \& Wilde, impression of leaf showing long spiny lobes, ZD RUP 96. • C - ?cf. "Viburnum" atlanticum Ettingshausen, incomplete leaf compression with cuticle, NM G 9433b, RU 60-14. • D - cf. "Viburnum" atlanticum Ettingshausen, leaf compression, NM G 9439a, RU 45. • E - cf. "Viburnum" atlanticum Ettingshausen, fragmentary leaf compression, NM RU 48-6. • F - cf. "Viburnum" atlanticum Ettingshausen, leaf impression showing details of venation, ZD RUP $47 . \bullet \mathrm{G}-$ Dicotylophyllum deichmuelleri Kvaček \& Walther, leaf impression, ZD RUP 115. • H - Dicotylophyllum deichmuelleri Kvaček \& Walther, leaf impression, ZD RUP 123. • I - Dicotylophyllum deichmuelleri Kvaček \& Walther, leaf impression, ZD RUP 139. • J - Dicotylophyllum deichmuelleri Kvaček \& Walther, leaf impression, ZD RUP 116. K K - Juniperus pauli Kvaček, cuticle showing monocyclic stomata, NM G8783b, RU 44-11. • L - Taxodium dubium (Sternberg) Heer, cuticle showing rows of stomata, NM G8793e, RU 48-11B. • M - Tetraclinis salicornioides (Unger) Kvaček, cuticle with scattered stomatal pits, NM G 9420 b, RU 60. • N - Laurophyllum acutimontanum Mai, abaxial cuticle with sunken amphicycloparacytic stomata, NM G8808c. • O - Laurophyllum pseudoprinceps Weyland \& Kilpper, adaxial cuticle, NM G8762b, RU 43-1. • P - Laurophyllum pseudoprinceps Weyland \& Kilpper, abaxial cuticle with brachyparacytic stomata, NM G8762c, RU 43.1. Scale bars: A, B = 10 mm; C-J = 5 mm. Magnification: K-P $\times 300$. 
Zlatko Kvaček et al. • Eocene-Oligocene transition in North Bohemia
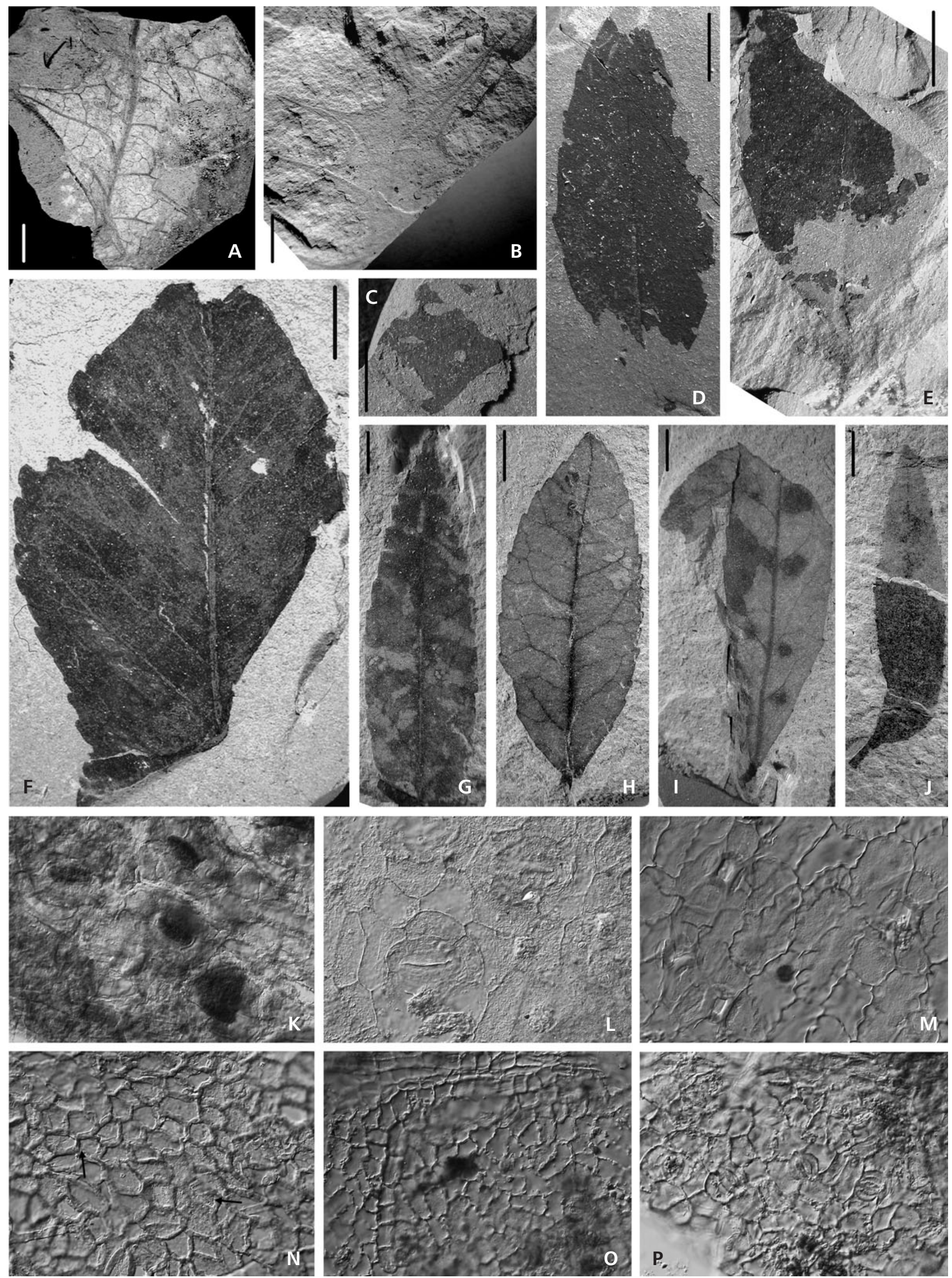
Miocene of Central Europe (Kvaček \& Walther 1981, as "Quercus" cruciata).

\section{cf. "Viburnum" atlanticum Ettingshausen}

Figures 5Q, 7C-F, 8J, K

? 1868 Viburnum atlanticum Ettingshausen, p. 209, pl. 36, fig. 2.

Material. - Fragmentary compressions - impressions, drill-cores RU 44, depth 18 m (NM G 8768a, G 9433 RU 44-5), RU 45a, depth 44-45 m (NM G 9439a, b, G 9444 b, d - RU 45a-1), RU 48, depth 52 m (RU 48-6), ? RU 60, depth 27.5-28 m (G 9433b - RU 60-14), outcrop (ZD RUP 47).

Description. - The leaf fragments assigned to this heterogenous morphotype are typically widely bluntly toothed, with steep, dense semicraspedodromous venation, partly with preserved epidermal anatomy: thin cuticles showing adaxially polygonal cells with slightly wavy anticlines, abaxially with hardly discernible stomata of anomocytic type. The direct identification with the not yet revised type material from Žichov without epidermal anatomy is equivocal, although in the general form the fragments studied are similar. Bůžek (1971) introduced a broad concept of $V$. atlanticum on the basis of the Miocene material, but later Bůžek et al. (1976) added some other specimens from the Oligocene of Markvartice that clearly differ. None of the so far described records can be safely compared with the material from Roudníky.

\section{Genus Dicotylophyllum Saporta}

\section{Dicotylophyllum deichmuelleri Kvaček \& Walther} Figures 7G-J, 8L

1998 Dicotylophyllum deichmuelleri Kvaček \& Walther, p. 14 , pl. 6, figs $7-12$, text-figs $13.7,13.30$.

Material. - Fragmentary leaf compression, drill-core RU 48, depth 52 m (NM G 8790 - RU 48-4), impressions, outcrop (ZD RUP 115, 116, 121, 123, 137, 138, 139, 140, 141, 142).

Description. - Petiolate, ovate leaves with widely dentate margin have been assigned to this element on account of a single compression with cuticle structure showing apparent paracytic stomata. Other impressions correspond in morphology with the records from Bechlejovice (Kvaček $\&$ Walther 2004) assigned to the same taxon. The type locality Kundratice (Kvaček \& Walther 1998) yielded better preserved material with epidermal anatomy. This leaf element is obviously evergreen and likely belongs to Symplocos. It differs only in details of epidermal structure (larger cells with wavy anticlinal walls vs isometrical straightwalled cells smaller than stomata) from Symplocos oligocaenica Kvaček mentioned above.

\author{
Animalia \\ Pisces \\ Order Esociformes Nelson, 1994 \\ Family Umbridae Bonaparte, 1846
}

\section{Genus Umbra Kramer, 1777}

\section{Umbra sp.}

Figure 10A-D

Material. - NM Pc 02893-Pc 02896 and unnumbered specimens, cores RU 40/76 and RU 60/94; Roudníky.

Description. - The scales are preserved as rounded imprints on the surface of the sediment. The nucleus is anteroposteriorly elongated. The circuli are arranged round the nucleus; they are joining together at the angle of about $50^{\circ}$ in the posterior part of the scale. Radii are not presented.

Remarks. - The specimens from Roudníky were described by Gaudant in Bellon et al. (1998). The specific features of the umbrid scales are rather limited and it is quite problematic to distinguish umbrid and palaeoesocid scales, so the determination is tentative. Remains of the genus Umbra were found in the Oligocene deposits of the sites of Bechlejovice and Odeř (Obrhelová 1978), early Miocene deposits

Figure 8. Locality Roudníky. • A - Laurophyllum pseudoprinceps Weyland \& Kilpper, abaxial cuticle near midrib with brachyparacytic stomata, NM G8809b. • B - Platanus neptuni (Ettingshausen) Bůžek, Holý \& Kvaček, adaxial cuticle with undulate anticlines, NM G 9403b, RU 60-9. - C - Platanus neptuni (Ettingshausen) Bủžek, Holý \& Kvaček, abaxial cuticle with stomata and a compound trichome base, NM G9403b, RU 60-9. -D - Alnus gaudinii (Heer) E. Knobloch \& Kvaček, abaxial cuticle with scattered stomata, NM G 8812c, RU 60-2. E - Rosa lignitum Heer, abaxial cuticle with scattered stomata, NM G9424e, RU 60-18A. • F - Pyracantha kraeuselii Walther in Mai \& Walther, adaxial cuticle, NM G 9432c,RU 60-16. - G - Pyracantha kraeuselii Walther in Mai \& Walther, abaxial cuticle, NM G 9432c, RU 60-16. $\bullet$ H - Symplocos oligocaenica Kvaček, adaxial cuticle, NM G9408c, RU 60-12. • I - Symplocos oligocaenica Kvaček, adaxial cuticle, NM G 9408c, RU 60-12. • J - cf. "Viburnum" atlanticum Ettingshausen, abaxial cuticle, NM G 9444d, RU45a-1B. • K - cf. "Viburnum" atlanticum Ettingshausen, adaxial cuticle, NM G 9444d, RU45a-1B. • L - cf. Dicotylophyllum deichmuelleri Kvaček \& Walther, abaxial cuticle with paracytic stoma, NM G8790c, RU48-4. Magnification: A-L × 300. 

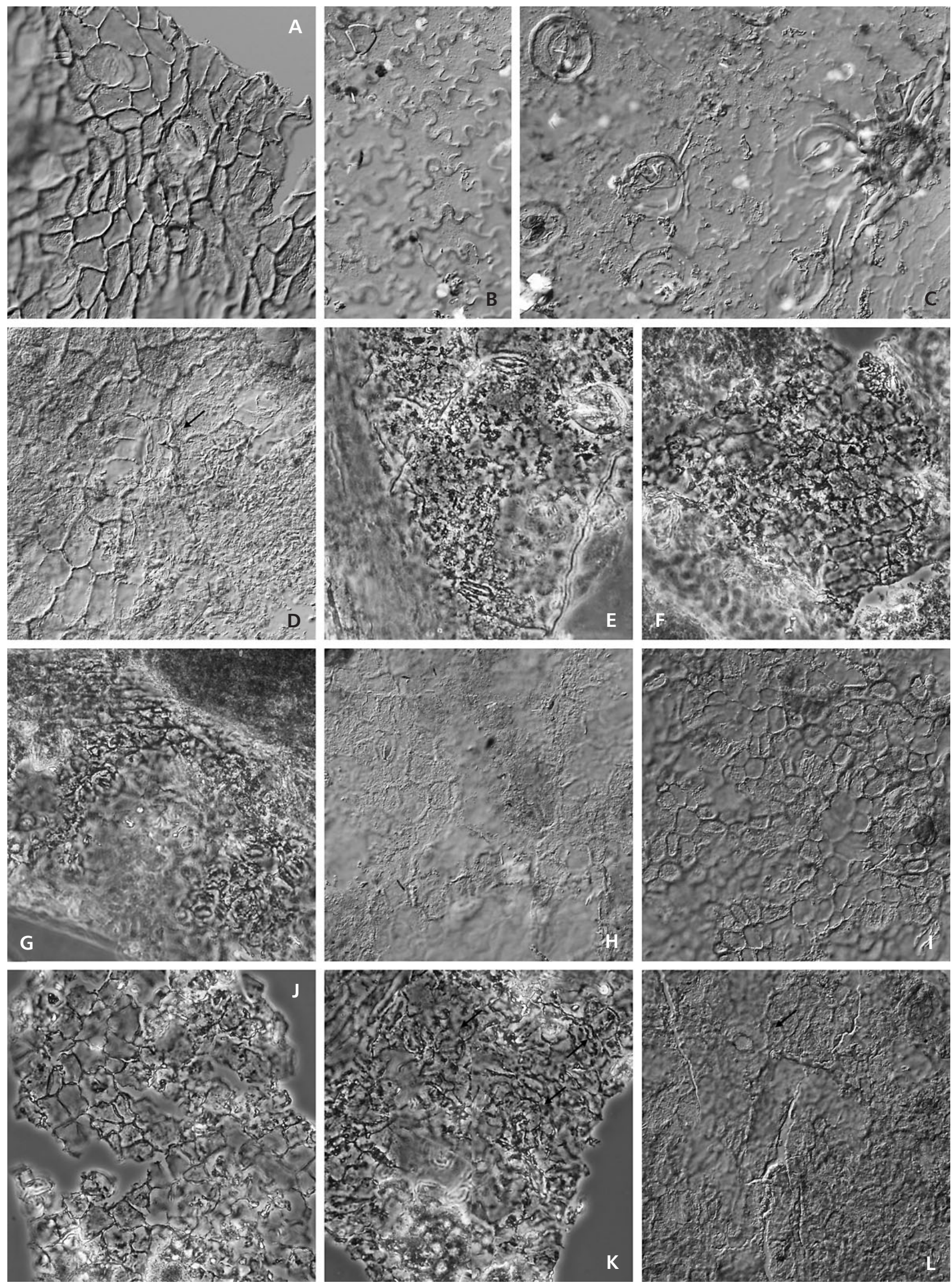
of the Mariana mine near Skyřice, the Merkur and Nástup mines (Obrhelová 1990) and from the Middle Miocene of Öhningen in Germany (Gaudant 2012). The species described as Umbra weileri (Martini 1965) from the Lower Oligocene of Sieblos was revised and moved to the genus Palaeoesox by Gaudant (2012).

Order Amiiformes Hay, 1929

Family Amiidae Bonaparte, 1832

\section{Genus Cyclurus Agassiz, 1844}

\section{Cyclurus sp.}

Figures 10E-M, 11A-Q

Material. - NM Pc 02897, Pc 02898 and unnumbered specimens, drill- cores RU 43, RU 43/31 and RU 60 (depth 94 m), Roudníky, outcrop: disarticulated skull bones ZD RU 165, 166 (part and counterpart) ZD RU 167, 168 (part and counterpart); dentary ZD RU 152; prearticular ZD RU 161-164; parasphenoideum RU 153; gulare mediale ZD RU 154-158; ceratohyal anterior ZD RU 159, 160 (part and counterpart); articulated caudal part of the body ZD RU 169, 170 (part and counterpart); isolated scales ZD RU 171-186; Větruše collection: unnumbered dentary (ZD). Větruše collection: isolated scales: RMT PA1247, PA1248 (part and counterpart), RMT PA1478, MT PA1479, RMT PA1485, RMT PA1486; teeth: RMT PA1487, RMT PA1488; isolated vertebrae: RMT PA1489/1, RMT PA1489/2 (part and counterpart), RMT PA1490.

Description. - The specimens from the Větruše Hill comprise isolated scales, teeth, vertebral centrae and jaw bone (Fig. 10E-K). The specimens from the Roudníky locality are represented by two groups: 1) the specimens from drill-cores (Fig. 10L, M) are typical isolated amioid scales (sensu Schultze 1966) that were described and figured in Bellon et al. (1998). 2) The specimens from the outcrop are represented mainly by isolated scales and by their groups, isolated bones, and partly disarticulated skeletons. They are classified to the genus Cyclurus on the basis of the following features (which are typical for the genus according to the Grande \& Bemis 1998 and Gaudant 2008): blunt-like coronoid teeth at the lower jaw (specimen ZD RU 165, Fig. 11B: the dark arrows show coronoid teeth; the white arrow shows one of the dentary tooth); the shape of the gulare mediale is subtriangular and truncated posteriorly (Fig. 11D); the heart-like shape of the tooth path on the ventral surface of the parasphenoid (Fig. 11C). Other specimens are not taxonomically significant. The scales represent majority of the collected specimens (see selected specimens in the Fig. 11G-Q). They are typical amioid scales (sensu Schultze 1966), their morphology is same as of the specimens from the Kučlín locality (see Prrikryl 2011). In some specimens it is possible to recognize annuli (e.g., ZD RU 172, see arrows in the Fig. 11I).

Remarks. - Remains of the genus Cyclurus were found in the Eocene of the Kučlín diatomite (Grande \& Bemis 1998, Gaudant 2008, Přikryl 2011) and the limestone of Kostomlaty (Obrhelová \& Obrhel 1987, Böhme 2007) as well as in the Eocene of Germany (localities Geiseltal and Messel Gaudant 1988). Other specimens of the genus Cyclurus are mentioned from the Late Cretaceous and Palaeocene of Canada, Palaeocene of Mongolia, upper Palaeocene and Eocene of France, Eocene deposits of the USA and Kazakhstan and exceptionally in the lowermost Oligocene of Germany at Sieblos (for details see Grande \& Bemis 1998).

Besides the fish remains described above also fossils of frogs (Palaeobatrachidae) are associated at the locality of Větruše. They are not treated in detail in this paper. The palaeobatrachids were restricted to the European region (for details see Wuttke et al. 2012).

\section{Palaeofloristic signals of the Roudníky flora}

The above described flora of Roudníky connected with the amiids fish assemblage and radiometricially dated to late

\footnotetext{
Figure 9. Locality Větruše. • A - Juniperus pauli Kvaček, leafy twig, RMT PA 1202/2. • B - Juniperus pauli Kvaček, seed cone, RMT PA 1201. - C - Juniperus pauli Kvaček, seed cone, RMT PA 1495/1. • D - Taxodium dubium (Sternberg) Heer, leafy twig, RMT PA 1204/1. • E - Tetraclinis salicornioides (Unger) Kvaček, leafy segment, RMT PA 1220. • F - Tetraclinis salicornioides (Unger) Kvaček, seed, RMT PA 1223 . • G - Laurophyllum cf. acutimontanum Mai, fragmentary leaf, RMT PA 1226. • H - Liriodendron sp., winged samara, RMT PA 1222/1. • I - Monocotyledonae gen. indet., leaf fragment, RMT PA 1209. • J - Platanus neptuni (Ettingshausen) Bůžek, Holý \& Kvaček, leaf, RMT PA 1224/1. • K - Daphnogene cinnamomifolia (Brongniart) Unger vel cf. Matudaea menzelii Walther, leaf fragment, RMT PA 1208 . $\bullet$ L - Alnus kefersteinii (Göppert) Unger, female infructescence on a fragmentary stalk, RMT PA 1215/1. • M - Ostrya atlantidis Unger, incomplete leaf compression, RMT PA $1208 . \bullet \mathrm{N}-$ Engelhardia orsbergensis (Wessel \& Weber) Jähnichen, Mai \& Walther, incomplete leaflet, RMT PA 1205. • O Engelhardia orsbergensis (Wessel \& Weber) Jähnichen, Mai \& Walther, incomplete leaflet, RMT PA 1206. P - Carya fragiliformis (Sternberg) Kvaček \& Walther, fragmentary leaflet, RMT PA 1225/1. • Q - Ulmus fischeri Heer, leaf fragment, RMT PA 1214. $・$ R - Rosa lignitum Heer, leaflet, RMT PA 1211. • S - Zelkova zelkovifolia (Unger) Bůžek \& Kotlaba, incomplete leaf, RMT PA 1219. • T - Craigia bronnii (Unger) Kvaček, Bůžek \& Manchester, capsule valve, RMT PA 1221/1. • U - Acer sp., samara, RMT PA 1239. $・$ V - Acer sp., incomplete leaf, RMT PA 1210/1. Scale bars: A-V = 5 mm.
} 
Zlatko Kvaček et al. • Eocene-Oligocene transition in North Bohemia
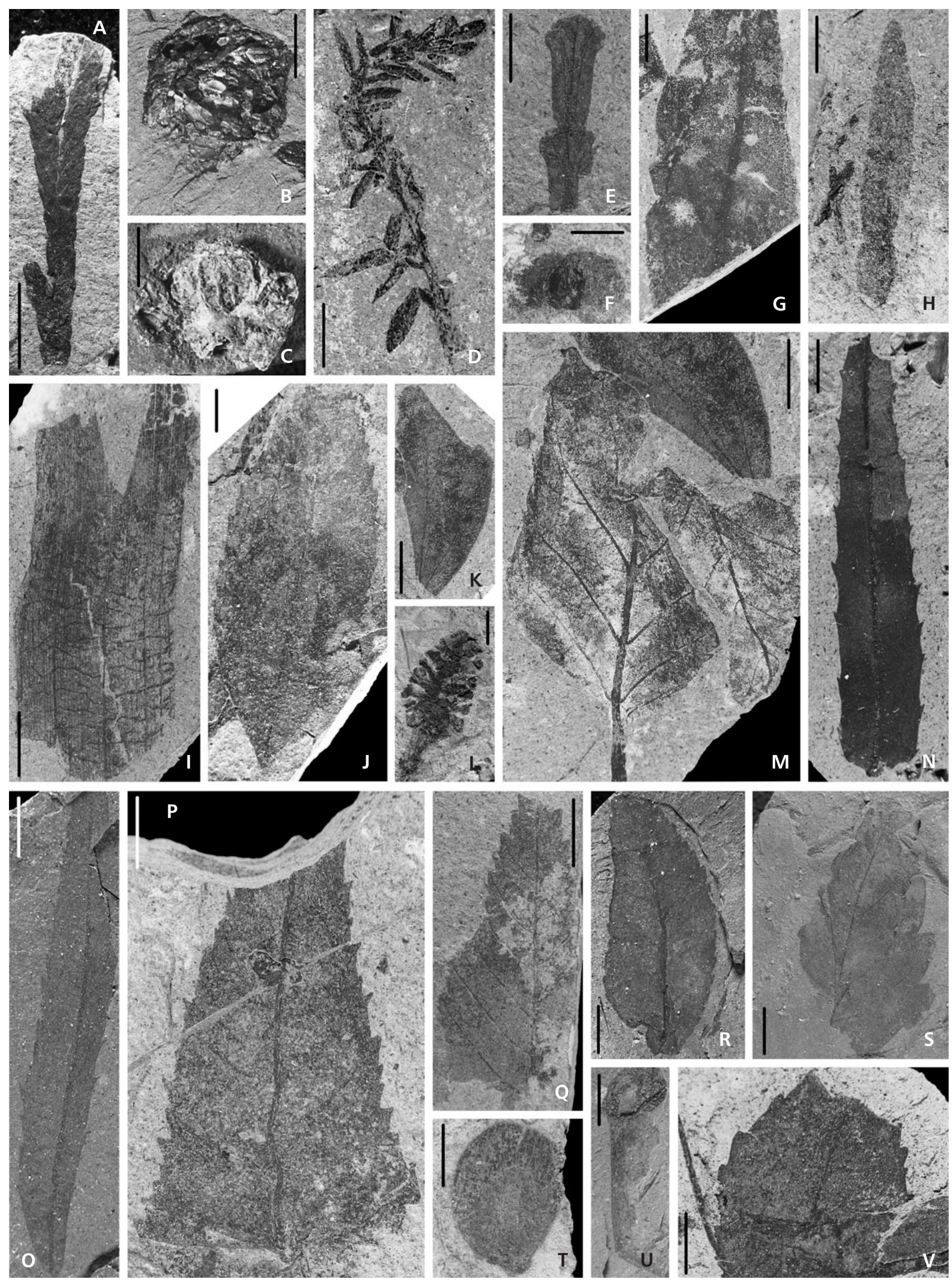
Eocene (Bellon et al. 1998) is dominated by broad-leaved deciduous ("modern Arcto-Tertiary") elements, e.g., Liriodendron, Ostrya, Alnus gaudinii, Betula sp., Carpinus mediomontana, Tilia, Carya, Cyclocarya, Cercidiphyllum, Acer sp., Ulmaceae (Ulmus, Zelkova) and Rosaceae (Rosa, Crategus, Pyracantha). Thermophilic elements are also present, including Lauraceae (Laurophyllum acutimontatum, L. pseudoprinceps), Symplocos, Nyssa, Fabaceae (Mimosites, Leguminosites, Gleditsia) and Platanus neptuni with post-Grande Coupure immigrants of conifers (Torreya, Cephalotaxus) and Craigia/Dombeyopsis. In view of its dating to late Eocene, this assemblage deviates from the others of this time interval in central Europe. None of the extinct subtropical plant markers characteristic of the European Eocene (Doliostrobus and Chamaecyparites of the conifers, extinct malvalean taxa of the group of Byttneriopsis, the juglandaceous Hooleya, the araceous Nitophyllites) have been found here. Only a few plants present at Roudníky cross the Eocene/Oligocene boundary elsewhere (e.g., Taxodium dubium, Tetraclinis salicornioides, Ziziphus ziziphoides, Pungiphyllum). Juniperus pauli is a noteworthy endemic conifer not known outside North Bohemia. The associated pollen spectra corroborate the deciduous character of the vegetation. They are rich in cupressoid and carpinoid pollen, lack the early Oligocene marker Boehlensipollis but include Intratripollenites microreticulatus Mai known mainly from the Eocene (Konzalová 1989, 2003). Most Arcto-Tertiary elements listed above are shared with the early Oligocene floras of central Europe, but do not appear in the Eocene. On the other hand, the early Oligocene (Kiscellian) floras of Budapest-Csillaghegy, Eger-Kiseged (Hungary, Hably 1985) contain several elements such as Doliostrobus, Raskya, Acrostichum characteristic of the late Eocene floras of the Bohemian Massif.

\section{Floristic comparison with the flora of the Větruše Hill and other late Eocene and early Oligocene sites of Central Europe}

A florule most similar to Roudníky, which is connected with the amiids, has been recovered in the diatomite of the Větruše Hill at Ústí/L. (Bůžek 1967, 1991; Radoň 2001). Most of the recovered plant elements (Fig. 9A-J, L, M, $\mathrm{P}-\mathrm{V})$ are shared with Roudníky, particularly Juniperis pauli besides Taxodium, Tetraclinis, Platanus neptuni, Liriodendron, Craigia, Zelkova, Alnus and Ostrya. Engelhardia is present at Větruše as macrofossils and at Roudníky as the pollen (Konzalová 1989, 2003). This plant assemblage is too poor for a more detailed statistical evaluation. Moreover, the adjacent basalts are not radiometrically dated.

The late Eocene flora of Kučlín (Kvaček 2002b, Kvaček \& Teodoridis 2011), which is stratigraphically and geographically close to Roudníky, is strikingly different, although only ca 2 million years older. The Kučlín assemblage does not show many affinities to late Eocene floras of the Staré Sedlo Formation (Knobloch et al. 1996, Teodoridis et al. 2012) and the Weisselster Basin (e.g., Haselbach, Kayna-Süd, Klausa, Knau, Phönix-Nord and Profen - Mai \& Walther 1985, 2000), probably due to difference in facies - volcanic assemblage of Kučlín vs. basinal assemblages of Staré Sedlo and the Weisselster Basin. These basinal floras are characterized by several phytostratigraphical markers such as Steinhauera subglobosa, Rhodomyrtophyllum reticulosum, Gordonia saxonica and Laurophyllum syncarpifolium associated with the predominant Eotrigonobalanus, and Daphnogene allowing the correlation of these floras to the late Eocene floristic assemblage of Hordle-Zeitz sensu Mai (1995). However, Doliostrobus is more often represented in late Eocene floras of Germany contrary to the Staré Sedlo Formation. The well diversified "volcanic" flora of Kučlín, according to the recent revision, includes many important Eocene, mostly extinct angiosperms, such as Raskya, Hooleya, and other, partly endemic or enigmatic elements, e.g., Nitophyllites, Trigonobalanopsis, Castaneophyllum, Byttneriopsis and Ternstroemites (Kvaček \& Teodoridis 2011, Teodoridis et al. 2012). Almost none of these plants are shared with the Roudníky assemblage.

The flora of Böhlen (Mai \& Walther 2000, outcrops 1 and 2 only) is based mainly on the carpological material and is interpreted as the youngest flora within the late Eocene sediments of the Weisselster Basin (Mosbrugger et al. 2005, level $\left.\mathrm{G}^{*}\right)$. The flora is hardly comparable with predominantly leaf floras of the Palaeogene of North Bohemia because of absence of phytostratigraphical markers. The flora of Böhlen shows a mixture of coniferous and broad-leaved evergreen (BLE) elements (Chamecyparites, Tetraclinis, Phoebe, Visnea, and Zenobia), of which only Tetraclinis is shared with Roudníky.

The above described phenomena of high abundance of the Arcto- Tertiary (broad-leaved deciduous) elements and the lack of Doliostrobus in the Roudníky flora show distinct linkage to the early Oligocene floras of the Doupov volcanic (Valeč, Dvérce, Vrbice) and České středohoří Mts complexes (Bechlejovice, Kundratice) rather than to the mentioned late Eocene floras of the Staré Sedlo Formation, Kučlín and the Weisselster Basin. Bůžek et al. (1968, 1987) reported from the lowermost limestone deposits of Valeč belonging to the Doupov volcanic complex a rare occurrence of Doliostrobus, which is an important marker related to the Eocene/Oligocene boundary and to the floristic assemblage of Bembridge sensu Mai (1995). Thin-bedded limestone and volcano-clastic rocks from the localities Valeč, Dvérce and Vrbice, which belong to higher parts of the Doupov complex, yielded floras showing a distinct early Oligocene character proved by occurrence of Alnus 

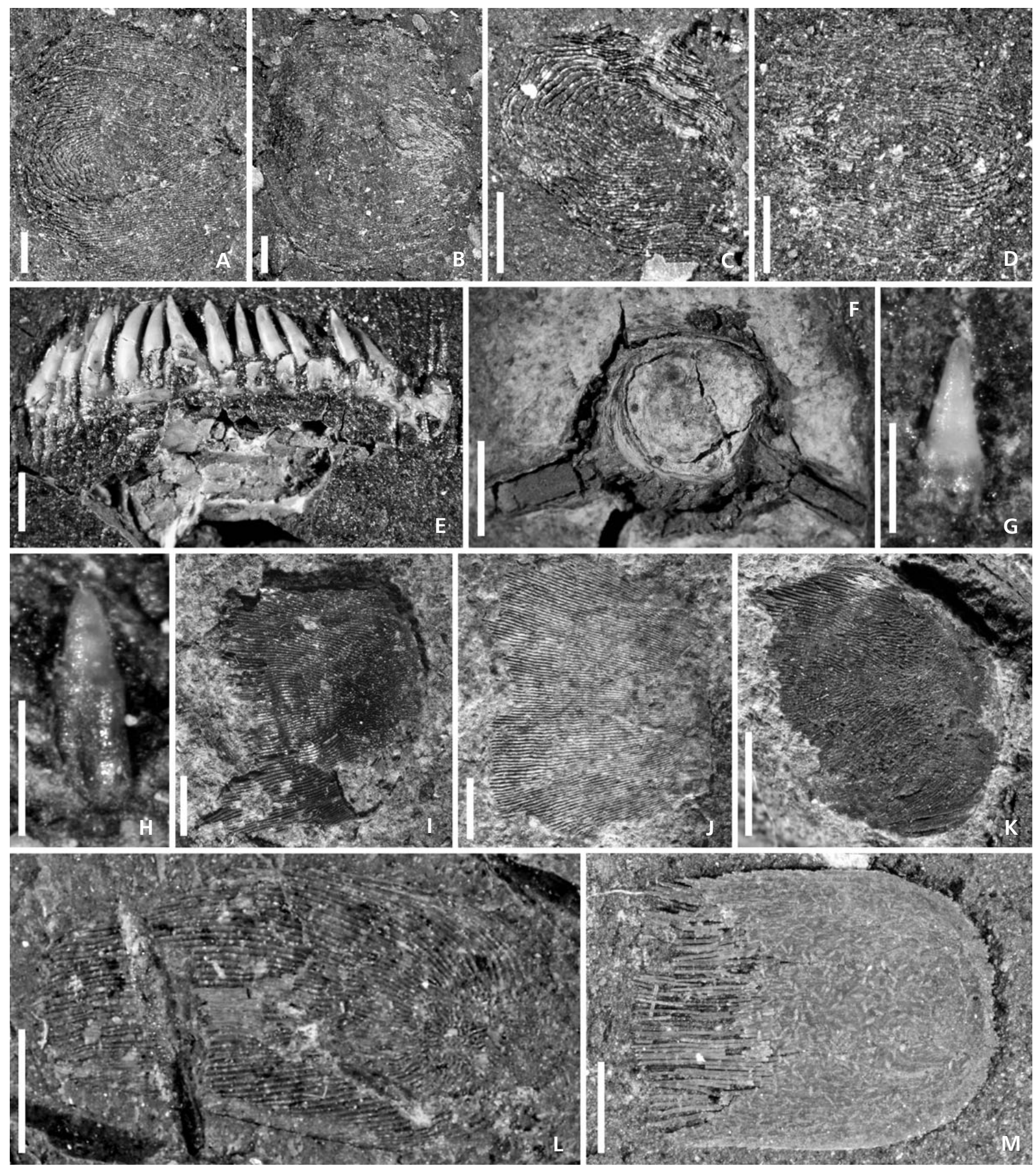

Figure 10. A - Umbra sp., scale, Roudníky, NM Pc02893, RU 60/94: 30.6-31.4 m. • B - Umbra sp., scale, Roudníky, NM Pc02894, RU 40/76: 14.1-14.4 m. • C - Umbra sp., scale, Roudníky, NM Pc02895, RU 40/76: 14.1-14.4 m. • D - Umbra sp., scale, Roudníky, NM Pc02896, RU 60/94: 30,6-31,4 m. • E - Cyclurus sp., jaw, Větruše, ZD unnumbered. $\bullet$ F - Cyclurus sp., vertebral centra, Větruše, RMT PA1490. $\bullet$ G - Cyclurus sp., isolated tooth, Větruše, RMT PA1487. • H - Cyclurus sp., isolated tooth, Větruše, RMT PA1488. • I - Cyclurus sp., scale, Větruše, RMT PA1486. • J - Cyclurus sp., scale, Větruše, RMT PA1248. • K - Cyclurus sp., scale, Větruše, RMT PA1247. • L - Cyclurus sp., scale, Roudníky, NM Pc02897, RU 43/31: 36-37 m. •M - Cyclurus sp., scale, Roudníky, NM Pc02898, RU 60/94: 41.5-41.7 m. Scale bars: E, F, K= 2 mm; G, H = 0.5 mm; A-D, I, J, L, M = 1 mm. 
rostaniana (cf. nostratum sensu Bůžek et al. 1987), Zelkova, Mahonia and Ulmus (Bůžek et al. 1990). The most diversified early Oligocene floras are known from the magmatic complex of the České stř̌edohoří Mts and Saxony, such as the floras of Bechlejovice (Kvaček \& Walther 2004), Kundratice (Kvaček \& Walther 1998), Knížecí-Hrazený (Knobloch 1961), Suletice-Berand (Kvaček \& Walther 1995), Holý Kluk (Radoň et al. 2006), Markvartice-Veselíčko (Bůžek et al. 1976), and Seifhennersdorf (Walther \& Kvaček 2007). These floras lack Doliostrobus, but include other coniferous elements, such as Torreya bilinica, Cephalotaxus parvifolia, Calocedrus suleticensis, in the combination with thermophilic broad-leaved elements (Platanus neptuni, "Acer" sotzkianum, Sloanea, Palaeohosiea, Engelhardia, Laurophyllum acutimontanum etc.) as well as newly appearing Arcto-Tertiary elements, e.g., Alnus gaudinii, Acer palaeosaccharinum, Acer angustilobum, Cercidiphyllum, Carya, Betula, Ostrya, Carpinus, Craigia, Zelkova, Ulmus fischeri etc. (Kvaček \& Walther 2001, 2003). Due to invasion of the mentioned deciduous "modern" Arcto-Tertiary elements into central Europe (e.g., Ostrya, Carpinus, Carya and Acer) associated with persisting Tetraclinis, Lauraceae and other thermophilic ("palaeosubtropical") elements, such as Engelhardia, Sloanea, Palaeohosiea, these floras are correlated to the floristic assemblage of Seifhennersdorf-Kundratice sensu Kvaček \& Walther (1998). The flora of Hammerunterwiesenthal in Saxony outside the Doupov volcanic complex (Walther 1998) is radiometrically dated to the early Oligocene (Rupelian) and can also be correlated to the floristic assemblage of Seifhennersdorf-Kundratice sensu Kvaček \& Walther (1998).

In scarcity of Daphnogene and low diversity of other Lauraceae and domination of Arcto-Tertiary elements, the Roudníly flora deviates from other late Eocene floras of the Bembridge-Spechbach floristic assemblage sensu Mai (1995). It does not resemble any of the so far known late Eocene sites in North Bohemia (Kostomlaty, Mrtvý vrch, Hlinná, Lbín) and adjacent regions.

\section{Fauna of Roudníky and Větruše}

The late Eocene fish localities are rather scarce in North Bohemia (compared with Oligocene localities, see Böhme
2007, table 2) being represented only by Roudníky, Kundratice (drill-core KU 1), Kostomlaty, and Kučlín. These are characterized mainly by the lack of the Cyprinidae fishes, which is in accordance with the situation in all of Europe. This remarkable absence was explained by Chang \& Chen (2000) as a time period before the Cyprinidae distribution from the source area to Europe.

The fish scale specimens from the Roudníky drill-cores were described by Bellon et al. (1998) who suggested Eocene age on the basis of the composition of the fish fauna and the radiometric dating. The fish fauna of the Roudníky area and the Větruše Hill is characterized by an overwhelming majority of amiid remains, that were also described from the Kučlín and Kostomlaty localities (late Eocene) in North Bohemia, where the amiids are accompanied also by thaumaturids (Thaumaturidae, Esociformes) and/or by other fish groups. The thaumaturids (as a subgroup of esociform order, see Gaudant \& Meunier 2004) are missing at the both localities studied, but at Roudníky the esociformes are represented by umbrids (specimens from the drill-cores). The today living umbrids are known for their ability to accept lower oxygen levels in water (Geyer \& Mann 1939a, b). The recent amiid bowfin Amia calva is also known for the ability to use the atmospheric air for respiration in an insufficiently oxygenated environment (e.g., Wilder 1878, Bevelander 1934). Such a poor diversity of the fish fauna can suggest the presence of a lake with sub-oxygenated waters that was inhabited by fishes able to accept such specific conditions. For the same reason other fish groups, for which the respiratory needs are higher, are missing.

The presence of the archaic amiid genus Cyclurus is typical of the Eocene localities in North Bohemia and elsewhere in Europe. The genus is not represented at the Kundratice outcrop (just perciform fish Properca bispinella is present; Obrhelová 1976), but this irregularity may be caused by the fact that the material from Roudníky comes mainly from the drill-cores. The Kučlín fish fauna is, together with Cyclurus macrocephalus, characterized by the thaumaturids, Percichthyidae and Moronidae (e.g., Obrhelová 1971, 1975; Micklich 1988, 1990; Micklich \& Bohme 1997; Gaudant 2008; Přikryl 2008). The genus Cyclurus is accompanied just by thaumaturids at the Kostomlaty locality (Obrhelová \& Obrhel 1987).

Figure 11. Locality Roudníky. • A - Cyclurus sp., dentary, ZD RU 152. • B - Cyclurus sp., detail of dentition, ZD RU 165 (the black arrows show coronoidal teeth, the white arrow shows tip of dentary's tooth). $\bullet$ C - Cyclurus sp., parasphenoideum, ZD RU 153 . $\bullet$ D - Cyclurus sp., gulare mediale, ZD RU 154. • E - Cyclurus sp., prearticular, ZD RU 163. $\bullet \mathrm{F}-$ Cyclurus sp., ceratohyal anterior, ZD RU 159 . $\bullet \mathrm{G}-$ Cyclurus sp., group of isolated scales, ZD RU 182. • H - Cyclurus sp., isolated scale of lateral line, ZD RU 174 (the arrow shows external opening of the lateral line system). $\bullet-C y c l u r u s$ sp., isolated scale, ZD RU 172 (the arrows show growing marks). $\bullet \mathrm{J}-\mathrm{Q}-$ Cyclurus sp., isolated scales showing variability of the specimens; J - Cyclurus sp., ZD RU 177; K - Cyclurus sp., ZD RU 178; L-ZD RU 175; M - Cyclurus sp., ZD RU 171; N - Cyclurus sp., ZD RU 183; O - Cyclurus sp., ZD RU 186; P-Cyclurus sp., ZD RU 180; Q - Cyclurus sp., ZD RU 179. Scale bars: A, C-G = 5 mm; B, H-Q = 1 mm. 

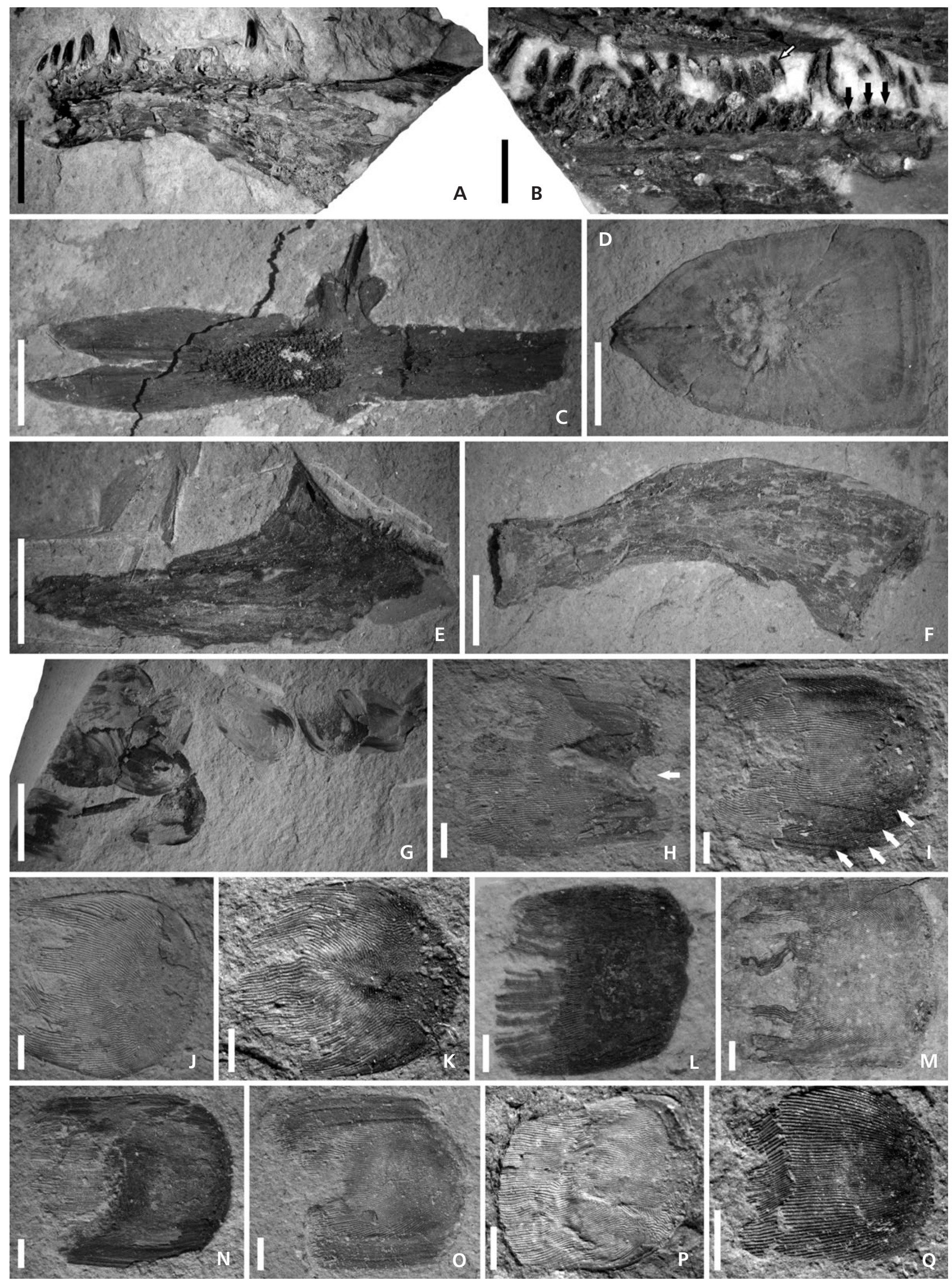
Table 1. Results and predicted zonal vegetation types defined by IPR-vegetation analysis for the studied fossil sites from late Eocene to early Oligocene of Northern Bohemia and Saxony (sensu Teodoridis et al. 2011b, table 8) including their GPS location and floristic sources.

\begin{tabular}{|c|c|c|c|c|c|c|c|c|}
\hline \multirow[b]{2}{*}{ Age } & \multirow[b]{2}{*}{ Localities } & \multirow[b]{2}{*}{ GPS } & \multirow[b]{2}{*}{ Reference } & \multirow[b]{2}{*}{ Dating } & \multicolumn{4}{|c|}{ IPR-vegetation results } \\
\hline & & & & & 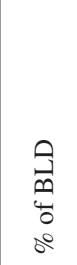 & $\begin{array}{l}\text { 亗 } \\
\overrightarrow{0} \\
0 \\
0 \\
0 \\
0\end{array}$ & 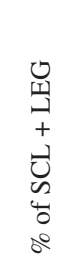 & $\begin{array}{l}\text { 省 } \\
\text { 岁 } \\
\text { 号 }\end{array}$ \\
\hline \multirow{6}{*}{ 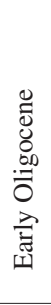 } & Seifhennersdorf & N $50^{\circ} 56^{\prime} 7.02^{\prime \prime}$, E $14^{\circ} 36^{\prime} 26.99^{\prime \prime}$ & Walther \& Kvaček (2007) & $30.44 \pm 1.25 \mathrm{Ma}$ & 59.44 & 33.54 & 5.10 & 1.92 \\
\hline & Hammerunterwiesenthal & $\mathrm{N} 50^{\circ} 34^{\prime} 36.89^{\prime \prime}$, E $13^{\circ} 0^{\prime} 17.52^{\prime \prime}$ & Walther (1998) & $30.5 \mathrm{Ma}$ & 54.64 & 36.08 & 3.09 & 6.19 \\
\hline & Holý Kluk & $\mathrm{N} 50^{\circ} 40^{\prime} 6.23^{\prime \prime}, \mathrm{E} 13^{\circ} 50^{\prime} 8.55^{\prime \prime}$ & Radoň et al. (2006) & $30.9 \pm 1.5 \mathrm{Ma}$ & 64.56 & 29.09 & 6.36 & 0.00 \\
\hline & Kundratice & $\mathrm{N} 49^{\circ} 24^{\prime} 8.94^{\prime \prime}$, E $16^{\circ} 8^{\prime} 6.76^{\prime \prime}$ & Kvaček \& Walther (1998) & $32.75 \pm 0.82 \mathrm{Ma}$ & 58.37 & 35.29 & 6.34 & 0.00 \\
\hline & Bechlejovice & N $50^{\circ} 45^{\prime} 23.77^{\prime \prime}$, E $14^{\circ} 14^{\prime} 16.55^{\prime \prime}$ & Kvaček \& Walther (2004) & $?$ & 62.51 & 26.60 & 9.92 & 0.93 \\
\hline & $\begin{array}{l}\text { Haselbach } \\
\text { (Haselbach FA) }\end{array}$ & $\mathrm{N} 51^{\circ} 8^{\prime} 24.00^{\prime \prime}, \mathrm{E} 12^{\circ} 24^{\prime} 36.00^{\prime \prime}$ & Mai \& Walther (1978) & $33.0-33.7$ & 50.03 & 42.48 & 4.26 & 3.23 \\
\hline \multirow{12}{*}{ 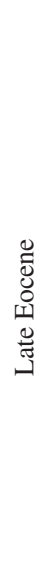 } & Větruše & N 5039' 17.94", E $14^{\circ} 2^{\prime} 22.81^{\prime \prime}$ & this paper & $?$ & 73.91 & 26.09 & 0.00 & 0.00 \\
\hline & Roudníky & N $50^{\circ} 38^{\prime} 57.96^{\prime \prime}$, E $13^{\circ} 55^{\prime} 10.51^{\prime \prime}$ & this paper & $35.4 \pm 0.9 \mathrm{Ma}$ & 59.09 & 28.79 & 12.12 & 0.00 \\
\hline & Böhlen & 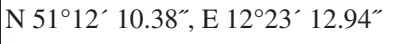 & Mai \& Walther $(1985,2000)$ & $35.5-37.0$ & 33.33 & 66.67 & 0.00 & 0.00 \\
\hline & Kayna-Süd & $\mathrm{N} 51^{\circ} 16^{\prime} 32.38^{\prime \prime}, \mathrm{E} 11^{\circ} 56^{\prime} 48.59^{\prime \prime}$ & & & 18.42 & 81.58 & 0.00 & 0.00 \\
\hline & Klausa & $\mathrm{N} 50^{\circ} 57^{\prime} 34.42^{\prime \prime}$, E $12^{\circ} 30^{\prime} 43.03^{\prime \prime}$ & & & 23.53 & 64.71 & 0.00 & 11.76 \\
\hline & Knau & N 50³9'10.02", E $11^{\circ} 43^{\prime} 17.15^{\prime \prime}$ & & & 8.11 & 91.89 & 0.00 & 0.00 \\
\hline & Profen & $\mathrm{N} 51^{\circ} 7^{\prime} 32.45^{\prime \prime}, \mathrm{E} 12^{\circ} 12^{\prime} 56.56^{\prime \prime}$ & & & 21.43 & 76.79 & 0.00 & 1.79 \\
\hline & Haselbach (Zeitz Sand) & $\mathrm{N} 51^{\circ} 8^{\prime} 24.00^{\prime \prime}$, E $12^{\circ} 24^{\prime} 36.00^{\prime \prime}$ & & & 12.96 & 79.63 & 0.00 & 7.41 \\
\hline & Kučlín & $\mathrm{N} 50^{\circ} 31^{\prime} 54.78^{\prime \prime}, \mathrm{E} 13^{\circ} 47^{\prime} 46.27^{\prime \prime}$ & Kvaček \& Teodoridis (2011) & $38.3 \mathrm{Ma}$ & 45.81 & 40.65 & 12.26 & 1.29 \\
\hline & Staré Sedlo & $\mathrm{N} 50^{\circ} 10^{\prime} 54.39^{\prime \prime}, \mathrm{E} 12^{\circ} 43^{\prime} 11.37^{\prime \prime}$ & $\begin{array}{l}\text { Knobloch et al. (1996), } \\
\text { Teodoridis et al. (2012) }\end{array}$ & $?$ & 25.00 & 59.21 & 2.63 & 13.61 \\
\hline & Český Chloumek & N 50 $6^{\prime} 51.89^{\prime \prime}$, E $12^{\circ} 56^{\prime} 50.54^{\prime \prime}$ & & $?$ & 21.88 & 65.63 & 0.00 & 6.91 \\
\hline & Nový Kostel & $\mathrm{N} 50^{\circ} 12^{\prime} 58.36^{\prime \prime}, \mathrm{E} 12^{\circ} 26^{\prime} 45.45^{\prime \prime}$ & & $?$ & 33.90 & 66.10 & 0.00 & 0.00 \\
\hline
\end{tabular}

The Roudníky fish fauna does not show much in common with the North Bohemian Oligocene fish localities. The only exception is that of Bechlejovice, which preserves umbrids (Obrhelová 1978) connecting both sites. At Roudníky a few isolated umbrid scales were found (Fig. 10J-M). Nevertheless, their presence shows indications of inhabitation of this area by umbrids, well documented later from the Oligocene and then successively to the Miocene (Obrhelová 1978, 1990; Kvaček et al. 2004).

Besides fish remains, the fauna of the Větruše Hill includes abundant teeth of crocodile Diplocynodon sp. (Radoň 2001). Quite rare frog remains (Palaeobatrachidae) from the Větruše locality correspond to other findings of anura in North Bohemia, both the Eocene (i.e., Kučlín) and the Oligocene in age (e.g., Bechlejovice). It seems that palaeobatrachids were not affected by the Eocene/Oligocene transition (Wuttke et al. 2012).

\section{Palaeoenvironmental analysis}

\section{Phytosociological approach}

Generally, Kvaček (2010) defined the zonal vegetation type of Mid-latitude Notophyllous Broad-leaved Evergreen Forest typified by the middle Eocene floras of Eckfeld (Germany) and Lábatlan (Hungary) and the late Eocene floras of Hordle (England) and Kučlín (Czech Republic). The zonal vegetation type was interpreted as the upland vegetation analogue of the more azonal late Eocene floras known from the Staré Sedlo Formation and Weisselster Basin. They were assigned by Kvaček (2010) to the broad-leaved evergreen riparian gallery forest with palms (Staré Sedlo) and mixed Doliostrobus and/or Quasisequoia and broad-leaved evergreen swamp forest (Weisselster Basin). Comparing the above mentioned plant assemblages - with the early Oligo- 
Table 1. continued

\begin{tabular}{|c|c|c|c|c|c|c|c|}
\hline \multirow[b]{2}{*}{ 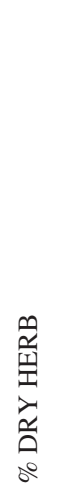 } & \multicolumn{7}{|c|}{ IPR-vegetation results } \\
\hline & 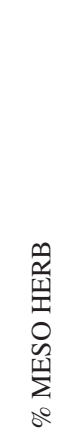 & 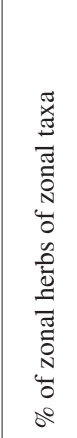 & 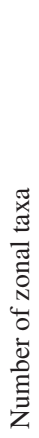 & 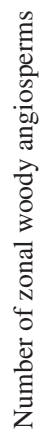 & 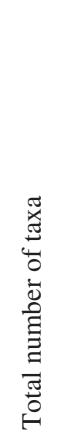 & 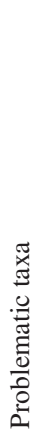 & $\begin{array}{l}\text { Vegetation type } \\
\text { sensu Teodoridis } \\
\text { et al. }(2011 \mathrm{~b})\end{array}$ \\
\hline 0.00 & 2.65 & 2.60 & 58 & 52 & 82 & 3 & MMF/BLEF \\
\hline 0.00 & 0.00 & 0.00 & 18 & 16 & 23 & 1 & MMF/BLEF \\
\hline 0.00 & 3.56 & 3.56 & 42 & 37 & 53 & 2 & MMF \\
\hline 0.00 & 0.84 & 0.84 & 60 & 55 & 75 & 5 & MMF/BLEF \\
\hline 0.00 & 3.64 & 3.64 & 55 & 51 & 68 & 0 & MMF \\
\hline 2.90 & 4.35 & 7.25 & 34 & 30 & 64 & 1 & BLEF \\
\hline 0.00 & 0.00 & 0.00 & 14 & 12 & 17 & 0 & MMF \\
\hline 0.00 & 0.00 & 0.00 & 38 & 33 & 45 & 1 & MMF \\
\hline 0.00 & 11.11 & 11.11 & 9 & 6 & 14 & 1 & BLEF (excluded) \\
\hline 0.00 & 11.36 & 11.36 & 22 & 19 & 36 & 0 & BLEF \\
\hline 0.00 & 5.41 & 5.41 & 19 & 16 & 26 & 0 & BLEF \\
\hline 0.00 & 4.76 & 4.76 & 30 & 19 & 21 & 3 & BLEF \\
\hline 0.00 & 0.00 & 0.00 & 31 & 28 & 45 & 0 & BLEF \\
\hline 0.00 & 4.69 & 4.69 & 32 & 26 & 49 & 3 & BLEF \\
\hline 0.81 & 2.64 & 3.45 & 82 & 78 & 106 & 6 & BLEF \\
\hline 0.00 & 3.37 & 3.37 & 45 & 38 & 47 & 1 & BLEF \\
\hline 0.00 & 0.00 & 0.00 & 17 & 16 & 18 & 0 & BLEF \\
\hline 0.00 & 0.00 & 0.00 & 30 & 30 & 32 & 0 & BLEF \\
\hline
\end{tabular}

cene vegetation types of the Doupov volcanic complex (locality Valeč) and the České středohoří Mts (Bechlejovice, Kundratice), a distinct decrease of broad-leaved evergreen elements close to the Eocene/Oligocene boundary is obvious. It corresponds to an enormous immigration of riparian deciduous broad-leaved elements from Asia to Europe (Kvaček \& Teodoridis 2007). This trend is now reported from the specific floras of Roudníky (this paper) and Böhlen (Mai \& Walther 1985, 2000), where the florisitic composition is significantly different from Kučlín and Staré Sedlo and its vegetation character corresponds to the modern Mixed-Mesophytic Forest vegetation type from SE Asia. The same vegetation type is supposed for the mentioned early Oligocene sites of Bechlejovice (Kvaček \& Walther 2004, p. 51), Kundratice (Kvaček \& Walther 1998, p. 31), Hammerunterwiesenthal (Walther 1998, p. 252) and Seifhennersdorf (Walther \& Kvaček 2007, p. 131).

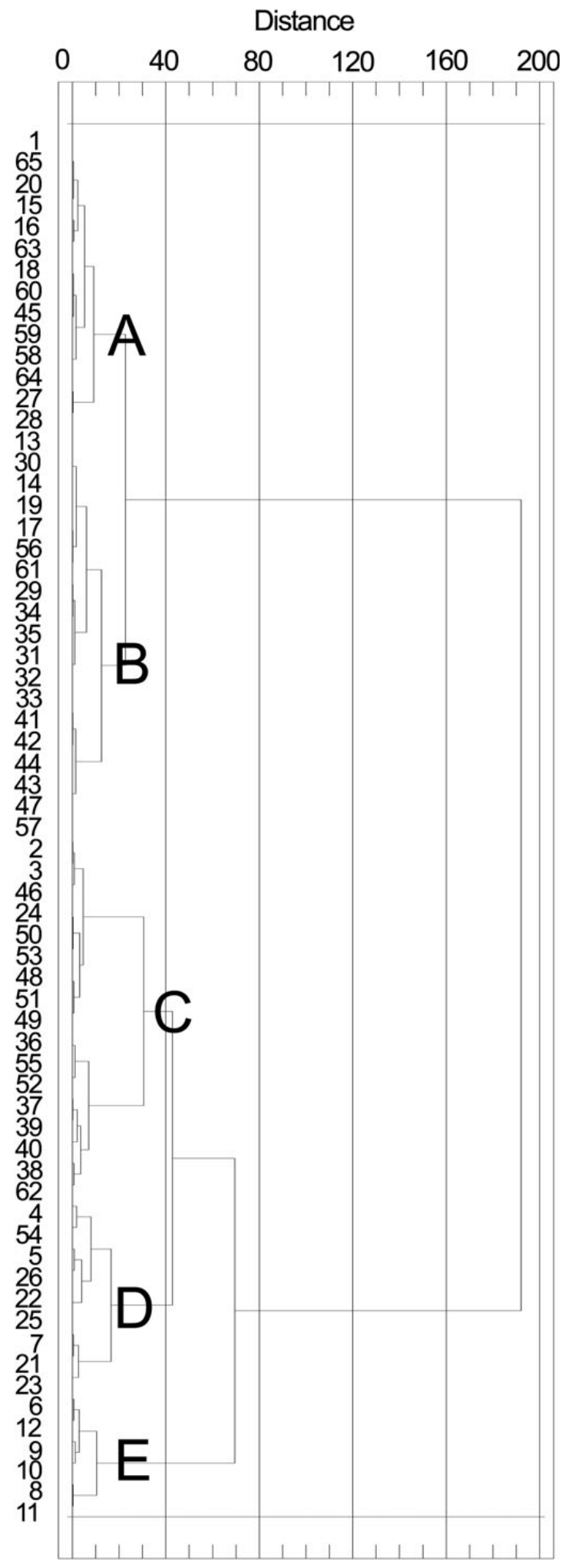

Figure 12. Dendrogram (Ward's method, squared Euclidean distance) showing one defaulted cluster based on the percentage of the BLD, BLE, and SCL+LEG components (sensu Teodoridis et al. 2011b, 2012) on the studied fossil and modern sites from China and Japan. Numbers represent the studied sites (DATA source in Appendix 3). Five subclusters (A to E) are distinguished. 
Table 2. Palaeoclimate proxy datasets of the Leaf Margin Analysis (LMA) and Climate Leaf Analysis Multivariate Program (CLAMP) for the studied floras from Northern Bohemia and Saxony. Symbols: SE (sampling error), $n$ (total species number), MAT (mean annual temperature), WMMT (warmest month mean temperature), CMMT (coldest month mean temperature), 3-WET (precipitation during 3 consecutive wettest months), 3-DRY (precipitation during 3 consecutive driest months), GROWSEAS (length of the growing season), GSP (growing season precipitation), MMGSP (mean monthly growing season precipitation), RH (relative humidity), SH (specific humidity) and ENTHAL (enthalpy), and STDEV Residuals (standard deviations).

\begin{tabular}{|c|c|c|c|c|c|c|c|c|c|c|c|c|c|}
\hline \multirow[t]{3}{*}{ Age } & \multirow[t]{3}{*}{ Localities } & \multicolumn{11}{|c|}{ Palaeoclimatic estimates } & \multirow[t]{3}{*}{ References } \\
\hline & & \multicolumn{5}{|c|}{ LMA } & \multicolumn{6}{|c|}{ CLAMP } & \\
\hline & & $\begin{array}{c}\text { MAT 1 } \\
{\left[{ }^{\circ} \mathrm{C}\right]} \\
\text { sensu } \\
\text { Wolfe } \\
(1979)\end{array}$ & $\begin{array}{c}\text { MAT } 2 \\
{\left[{ }^{\circ} \mathrm{C}\right]} \\
\text { sensu } \\
\text { Su } \text { et al. } \\
(2010)\end{array}$ & $\begin{array}{l}\text { SE 1 } \\
{\left[{ }^{\circ} \mathrm{C}\right]} \\
\text { sensu } \\
\text { Wilf } \\
(1997)\end{array}$ & $\begin{array}{l}\text { SE 2 } \\
{\left[{ }^{\circ} \mathrm{C}\right]} \\
\text { sensu } \\
\text { Miller } \\
\text { et al. } \\
(2006)\end{array}$ & $\mathrm{n}$ & $\begin{array}{l}\mathrm{MAT}\left[{ }^{\circ} \mathrm{C}\right] \\
(\mathrm{STDEV})\end{array}$ & $\begin{array}{c}\text { WMMT } \\
{\left[{ }^{\circ} \mathrm{C}\right]} \\
(\mathrm{STDEV})\end{array}$ & $\begin{array}{l}\text { CMMT } \\
{\left[{ }^{\circ} \mathrm{C}\right]} \\
(\mathrm{STDEV})\end{array}$ & $\begin{array}{c}\text { 3-WET } \\
{[\mathrm{cm}]} \\
(\mathrm{STDEV})\end{array}$ & $\begin{array}{c}3-\mathrm{DRY} \\
{[\mathrm{cm}]} \\
(\mathrm{STDEV})\end{array}$ & $\begin{array}{l}\text { CLAMP } \\
\text { calibration } \\
\text { datasets }\end{array}$ & \\
\hline \multirow{6}{*}{$\begin{array}{l}\text { Early } \\
\text { Oligocene }\end{array}$} & Seifhennersdorf & 13.3 & 11.7 & 2.1 & 2.4 & 49 & $11.3(1.2)$ & $23.5(1.4)$ & $0.7(1.9)$ & $81.3(13.8)$ & $17.4(3.2)$ & 144 & this paper \\
\hline & Holý Kluk & 10.8 & 9.5 & 2.8 & 2.8 & 26 & $10.2(1.6)$ & $19.2(1.8)$ & $2.8(2.2)$ & $43.1(13.1)$ & $10.2(3.5)$ & 173 & this paper \\
\hline & Hammerunterwiesenthal & - & - & - & - & - & $11.3(1.2)$ & $25.4(1.4)$ & $-1.5(1.9)$ & $66.4(13.8)$ & $18.0(3.2)$ & 144 & this paper \\
\hline & Kundratice & 14.2 & 12.6 & 1.9 & 2.3 & 61 & $12.1(1.2)$ & $23.5(1.4)$ & $2.4(1.9)$ & $84.7(13.8)$ & $17.1(3.2)$ & 144 & this paper \\
\hline & Bechlejovice & 10.8 & 9.5 & 2.0 & 2.2 & 52 & $11.1(1.2)$ & $21.1(1.4)$ & $2.1(1.9)$ & $82.5(13.8)$ & $21.7(3.2)$ & 144 & this paper \\
\hline & $\begin{array}{l}\text { Haselbach 1, Beucha } \\
\text { (Haselbach FA) }\end{array}$ & 13.7 & 12.1 & 3.4 & 3.4 & 20 & $11.6(1.3)$ & $23.3(1.7)$ & $0.6(2.6)$ & $51.4(16.6)$ & $10.4(5.0)$ & 189 & this paper \\
\hline \multirow{8}{*}{$\begin{array}{l}\text { Late } \\
\text { Eocene }\end{array}$} & Roudníky & 9.5 & 8.4 & 2.4 & 2.5 & 32 & $10.0(1.2)$ & $21.6(1.4)$ & $0.0(1.9)$ & $82.3(13.8)$ & $13.7(3.2)$ & 144 & this paper \\
\hline & Haselbach (Zeitz FA) & 20.1 & 17.9 & 5.0 & 4.7 & 9 & - & - & - & - & - & - & $\begin{array}{l}\text { Teodoridis } \\
\text { et al. }(2012)\end{array}$ \\
\hline & Knau (Zeitz FA) & 21.4 & 19.1 & 4.2 & 3.9 & 10 & - & - & - & - & - & - & \\
\hline & $\begin{array}{l}\text { Haselbach, Klausa, } \\
\text { Knau (Zeitz floristic } \\
\text { assemblage - FA) }\end{array}$ & 22.7 & 20.2 & 3.3 & 3.3 & 18 & $17.1(1.3)$ & $23.7(1.7)$ & $9.1(2.6)$ & $54.1(16.6)$ & $8.6(5.0)$ & 189 & \\
\hline & Kučlín & 23.0 & 20.5 & 1.6 & 1.9 & 78 & $16.8(1.3)$ & $26.1(1.7)$ & $8.1(2.6)$ & $54.3(16.6)$ & $11.8(5.0)$ & 189 & $\begin{array}{l}\text { Kvaček \& } \\
\text { Teodoridis } \\
(2011)\end{array}$ \\
\hline & Staré Sedlo & 21.2 & 18.9 & 2.2 & 2.4 & 44 & $16.2(1.3)$ & $25.9(1.7)$ & $6.3(2.6)$ & $59.4(16.6)$ & $12.0(5.0)$ & 189 & $\begin{array}{l}\text { Teodoridis } \\
\text { et al. }(2012)\end{array}$ \\
\hline & Český Chloumek & 21.4 & 19.1 & 4.0 & 3.9 & 13 & - & - & - & - & - & - & \\
\hline & Nový Kostel & 26.1 & 23.3 & 2.9 & 2.7 & 18 & - & - & - & - & - & - & \\
\hline
\end{tabular}

\section{IPR-vegetation analysis}

The fossil plant assemblages of Roudníky and Větruše were compared using IPR-vegetation analysis (e.g., Kovar-Eder et al. 2008, Teodoridis et al. 2011b) of the following characteristic key components: broad-leaved deciduous (BLD) $59.1 \%$ and $73.9 \%$, broad-leaved evergreen (BLE) $-28.8 \%$ and $26.1 \%$, sclerophyllous + legume-like (SCL+LEG) $12.1 \%$ and $0 \%$, dry herbaceous + mesophytic herbaceous /zonal herbaceous/ (D-HERB+M-HERB/ZONAL HERB/) both $0 \%$ (for a detailed taxa scoring see Appendix 2). According to the thresholds for the key components detailed above for defining vegetation types (modified by Teodoridis et al. 2011b, table 8), the floras of Roudníky and Větruše belong to the mixed mesophytic forest (MMF) vegetation type. Results of the IPR-vegetation analysis from the late Eocene and early Oligocene floras from the Bohemian Massif and Saxony (Germany) are presented in Table 1. According to these results, the studied late Eocene floras correspond to the broad-leaved evergreen forest (BLEF) vegetation type as a possible zonal vegetation cover for upland environments. However, the studied vegetation assemblages of BLEF from the Weisselster Basin are characterized by a relatively high percentage of the BLE elements (65 to 92\%) contrary to those from the Staré Sedlo Formation, Kučlín and Roudníky, which varies from 40 to $66 \%$ (Teodoridis et al. 2012; partly Table 1). Moreover, the assemblages of Kučlín and Roudníky also show a high percentage of sclerophyllous and legume-like elements (12.1\% and 14.2\%), which is a rare phenomenon in the late Eocene floras of Europe. The results of IPR-vegetation analysis from the studied early Oligocene sites from the Bohemian Massif and Saxony (i.e., Haselbach, Bechlejovice, Kundratice, Hammerunterwiesenthal, Holý Kluk and Seifhennersdorf) show relatively low percentage of BLE components $(27-42 \%)$ and higher percentage of BLD components (50-59\%) contrary to those from the late Eocene sites of the Staré Sedlo Formation and the Weisselster Basin. The percentage of SCL+LEG component varies from 3 to $10 \%$. The ratios of the key components (Table 1) permit assign- 


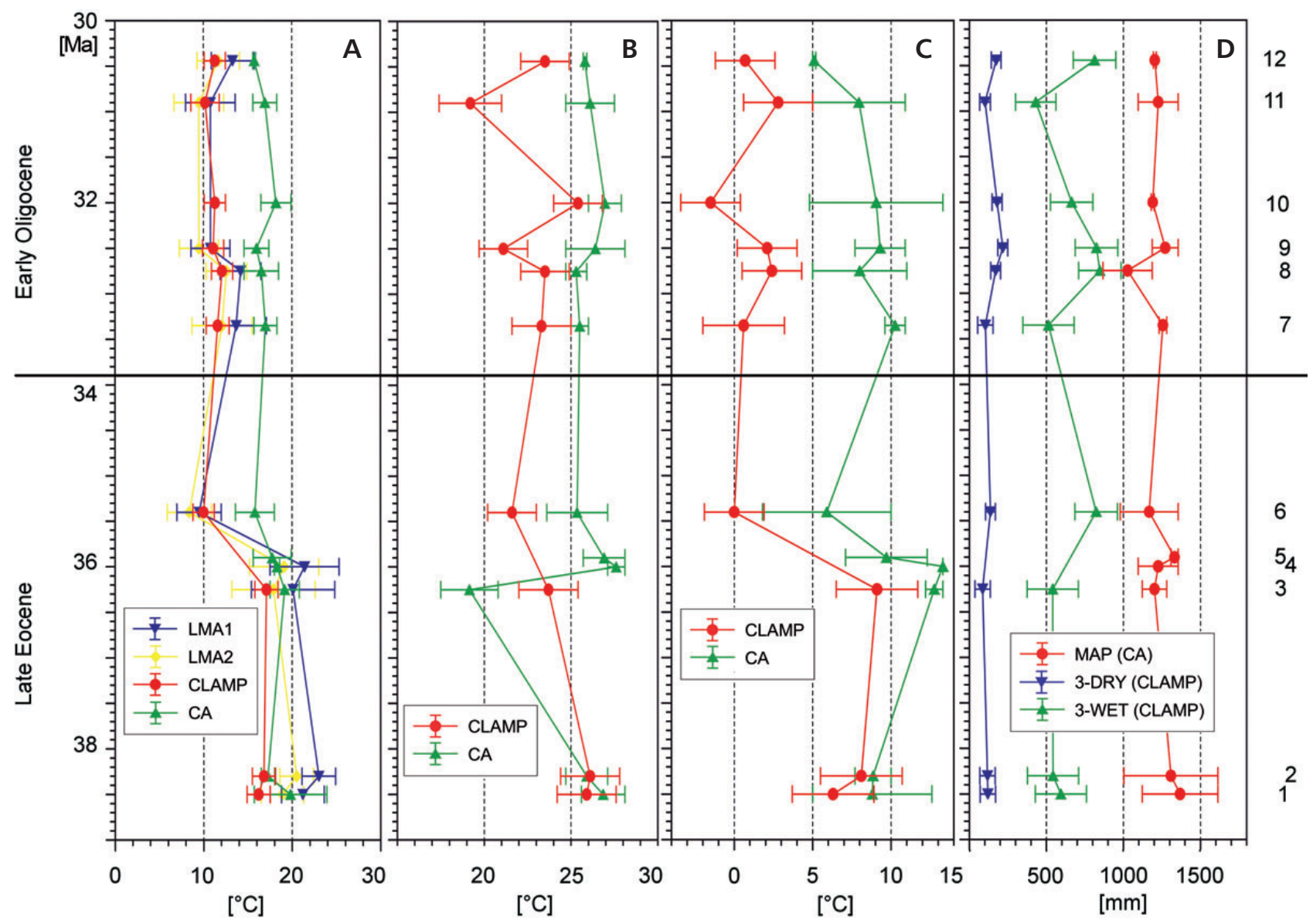

Figure 13. Palaeoclimatic changes and trends based on the proxy-datasets of the studied parameters derived from the LMA, CLAMP and CA techniques during late Eocene to early Oligocene. Palaeoclimatic parameters: A - MAT (mean annual temperature); B - WMMT (mean temperature of the warmest month); C-CMMT (mean temperature of the coldest month); D-MAP (mean annual precipitation); 3-WET (precipitation during 3 consecutive wettest months) and 3-DRY (precipitation during 3 consecutive driest months). Symbols: 1 - Staré Sedlo, 2 - Kučlín, 3 - Haselbach, Klausa, Knau (Zeitz FA), 4 - Knau (Zeitz FA), 5 - Böhlen, 6 - Roudníky, 7 - Haselbach 1, Beucha (Haselbach FA), 8 - Bechlejovice, 9 - Kundratice, 10 - Hammerunterwiesenthal, 11 - Holý Kluk and 12 - Seifhennersdorf.

ment to the vegetation type of mixed mesophytic forest (MMF) at Bechlejovice and Holý Kluk sites and to the ecotonal vegetation of BLEF/MMF at Kundratice, Hammerunterwiesenthal and Seifhennersdorf sites. Only the early Oligocene vegetation type of Haselbach corresponds to BLEF (see Table 1).

According to Teodoridis et al. (2012) a modern living vegetation analogue of the studied late Eocene vegetation of Nový Kostel, Český Chloumek, Staré Sedlo, Žitenice, Klausa, Phönix-Nord, and Profen is the subtropical broadleaved evergreen forest of Mt. Emei (Sichuan, China) and of Mt. Longqi (Fujian, China) based on the results of the cluster analysis comparing 47 modern vegetation units from subtropical and tropical zones of China and Japan and 14 late Eocene fossil vegetation types from the Weisselster, Cheb and Sokolov basins (for details see Teodoridis et al. 2012; partly Fig. 13 - clusters "A", "B", source Appendix 3). However, a dendrogram (Fig. 12) derived from the cluster analysis (Ward's method, Euclidean square distance sensu Teodoridis et al. 2011b, 2012) does not prove the above mentioned statements for the vegetation of Větruše (54), Roudníky (55) and Kučlín (62). The two latter sites show the closest relation to the early Oligocene flora of Bechlejovice (52) in a cluster marked as "C" (Fig. 12). Focusing on the structure of cluster "C", it is obvious that the late Eocene sites of Roudníky and Kučlín are related to the studied early Oligocene sites rather than to the late Eocene sites from the Staré Sedlo Formation and the Weisselster Basin. The cluster "C" shows an affinity of the early Oligocene floras such as Holý Kluk (49), Kundratice (51), Seifhennersdorf (48), Haselbach (53), and Hammerunterwiesenthal (50), to the modern vegetation assemblages of specific vegetation samples of the BLEF type from Mt. Fuji, Japan (24), Mixed Mesophytic Forest vegetation type from Mt. Emei, China (2, 3) and Monsoon vegetation type from Xishuangbanna, China (46). Similarly, cluster "C" presents close relation of the modern MMF vegetation associations of Eurya-Cryptomeria japonica 
Table 3. Palaeoclimate proxy datasets of the Coexistence Approach (CA) for the studied floras from Northern Bohemia and Saxony. Symbols: MAT (mean annual temperature), WMMT (mean temperature of the warmest month), CMMT (mean temperature of the coldest month), and MAP (mean annual precipitation).

\begin{tabular}{|c|c|c|c|c|c|c|c|c|c|c|c|}
\hline \multirow[t]{3}{*}{ Age } & \multirow{3}{*}{\multicolumn{2}{|c|}{ Localities }} & \multicolumn{8}{|c|}{ Palaeoclimatic estimates } & \multirow[t]{3}{*}{ References } \\
\hline & & & \multicolumn{2}{|c|}{$\operatorname{MAT}\left[{ }^{\circ} \mathrm{C}\right]$} & \multicolumn{2}{|c|}{ WMMT $\left[{ }^{\circ} \mathrm{C}\right]$} & \multicolumn{2}{|c|}{$\mathrm{CMMT}\left[{ }^{\circ} \mathrm{C}\right]$} & \multicolumn{2}{|c|}{$\mathrm{MAP}[\mathrm{mm}]$} & \\
\hline & & & $\begin{array}{c}\text { min. } \\
\text { value }\end{array}$ & $\begin{array}{l}\max . \\
\text { value }\end{array}$ & $\begin{array}{c}\text { min. } \\
\text { value }\end{array}$ & $\begin{array}{l}\max . \\
\text { value }\end{array}$ & $\begin{array}{c}\text { min. } \\
\text { value }\end{array}$ & $\begin{array}{l}\max . \\
\text { value }\end{array}$ & $\begin{array}{c}\text { min. } \\
\text { value }\end{array}$ & $\begin{array}{l}\max . \\
\text { value }\end{array}$ & \\
\hline \multirow{9}{*}{ 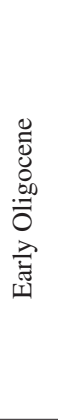 } & \multicolumn{2}{|l|}{ Seifhennersdorf } & 15.6 & 15.9 & 25.7 & 25.9 & 5.0 & 5.2 & 1194.0 & 1213.0 & Mosbrugger et al. (2005) \\
\hline & \multicolumn{2}{|l|}{ Holý Kluk } & 15.6 & 18.3 & 24.7 & 27.5 & 5.0 & 10.9 & 1096.0 & 1355.0 & Utescher (personal communication 2013) \\
\hline & \multicolumn{2}{|c|}{ Hammerunterwiesenthal } & 16.5 & 19.9 & 26.0 & 27.9 & 4.8 & 13.3 & 1180.0 & 1200.0 & Utescher (personal communication 2013) \\
\hline & \multicolumn{2}{|c|}{ Kundratice } & 14.6 & 18.5 & 24.7 & 25.9 & 5.0 & 11.0 & 867.0 & 1187.0 & Utescher (personal communication 2013) \\
\hline & \multicolumn{2}{|l|}{ Bechlejovice } & 14.6 & 17.4 & 24.7 & 28.1 & 7.7 & 10.9 & 1187.0 & 1355.0 & Utescher (personal communication 2013) \\
\hline & Haselbach FA & Beucha & 15.6 & 16.1 & 24.7 & 25.6 & 5.0 & 5.8 & 897.0 & 1206.0 & Roth-Nebelsick et al. (2004) \\
\hline & & Regis & 16.5 & 23.9 & 26.0 & 27.9 & 9.6 & 13.6 & 1187.0 & 1281.0 & Roth-Nebelsick et al. (2004) \\
\hline & & Haselbach & 15.7 & 18.3 & 25.0 & 26.0 & 9.6 & 10.9 & 1231.0 & 1281.0 & Roth-Nebelsick et al. (2004) \\
\hline & \multicolumn{2}{|l|}{ Valeč } & 9.3 & 21.7 & 22.3 & 28.6 & 2.7 & 13.6 & 979.0 & 1741.0 & Utescher (personal communication 2013) \\
\hline \multirow{6}{*}{ 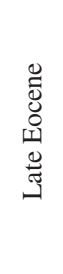 } & \multicolumn{2}{|l|}{ Roudníky } & 13.6 & 18.0 & 23.6 & 27.1 & 1.8 & 10.0 & 979.0 & 1355.0 & Utescher (personal communication 2013) \\
\hline & \multicolumn{2}{|l|}{ Böhlen } & 15.6 & 19.9 & 25.7 & 28.1 & 7.1 & 12.3 & 1308.0 & 1355.0 & Mosbrugger et al. (2005) \\
\hline & \multicolumn{2}{|c|}{ Haselbach (Zeitz FA) } & 17.5 & 20.8 & 27.1 & 27.9 & 12.2 & 13.3 & 1122.0 & 1281.0 & Mosbrugger et al. (2005) \\
\hline & \multicolumn{2}{|c|}{ Knau } & 18.0 & 18.6 & 27.1 & 28.1 & 13.3 & 13.3 & 1096.0 & 1355.0 & Mosbrugger et al. (2005) \\
\hline & \multicolumn{2}{|l|}{ Kučlín } & 16.5 & 18.0 & 24.7 & 27.1 & 7.7 & 10.0 & 1003.0 & 1613.0 & Kvaček \& Teodoridis (2011) \\
\hline & \multicolumn{2}{|l|}{ Staré Sedlo } & 15.7 & 23.9 & 25.6 & 28.1 & 5.0 & 12.6 & 1122.0 & 1613.0 & Teodoridis et al. (2012) \\
\hline
\end{tabular}

from the Yakushima Island, Japan only (38-40) to the mentioned fossil vegetation of Roudníky (55), Kučlín (62), and Bechlejovice (52). The remaining clusters " $D$ " and "E" in Fig. 12 group together modern vegetation types of broad-leaved deciduous forest (BLDF) from China and Japan associated with the studied vegetation type of Větruše (54). The vegetation of Větruše shows the closest relationship to the modern broad-leaved deciduous forest of the Mt. Emei (4) - Tang \& Ohsawa (1997). This clustering was influenced by a relatively higher percentage of the BLD component $(73.9 \%)$, which is secondarily caused by low value of zonal woody angiosperms (but still acceptable for use of IPR-vegetation analysis).

\section{Palaeoclimatic proxy-datasets}

The plant assemblage of Roudníky was evaluated using a combination of the physiognomic (LMA, CLAMP) and Nearest Living Relatives (CA) techniques. The CLAMP method uses the physiognomic characteristics of the Roudníky assemblage presented in Appendix 1 and 144 physiognomic and gridded meteorological calibration datasets (Physg3brcAZ, GRIDMet3brAZ) selected by a new statistical tool published by Teodoridis et al. (2012). The palaeoclimatic proxy-datasets for the Roudníky are as follows: CLAMP estimates - MAT $10.0{ }^{\circ} \mathrm{C}$, WMMT $21.6{ }^{\circ} \mathrm{C}$, CMMT $0.0^{\circ} \mathrm{C}$, 3-WET $82.3 \mathrm{~cm}$ and 3-DRY $13.7 \mathrm{~cm}$; LMA estimates - $\mathrm{MAT}_{1}$ is $9.5^{\circ} \mathrm{C}$ (sensu Wolfe 1979) and $\mathrm{MAT}_{2}$ is $8.4^{\circ} \mathrm{C}$ (sensu Su et al. 2010), and values of the sampling error sensu Miller et al. (2006) is $2.5^{\circ} \mathrm{C}$ and $2.4{ }^{\circ} \mathrm{C}$ sensu Wilf (1997); CA proxy data intervals: MAT $13.6-18.0^{\circ} \mathrm{C}$, WMMT 23.6-27.1 ${ }^{\circ} \mathrm{C}$, CMMT 1.8-10.0 ${ }^{\circ} \mathrm{C}$, and MAP 979-1355 mm (see Tables 2, 3). Contrary to the estimates of Roudníky, palaeoclimatic proxies from the other late Eocene floras of the Bohemian Massif and Saxony (partly Teodoridis et al. 2012, Kvaček \& Teodoridis 2011, Tables 2,3) show higher and almost balanced results in comparison with the used techniques, i.e., MAT: $16.2-17.1^{\circ} \mathrm{C}$ (CLAMP), $22.9^{\circ} \mathrm{C}$ and $20.5^{\circ} \mathrm{C}$ (LMA MAT $1_{\text {and }}$ LMA ${ }_{\text {MAT } 2-}-$ average values), $15.7-23.9^{\circ} \mathrm{C}(\mathrm{CA})$; WMMT: $23.7-26.1^{\circ} \mathrm{C}$ (CLAMP), 24.7-28.1 ${ }^{\circ} \mathrm{C}$ (CA); CMMT: 6.3-9.1 ${ }^{\circ} \mathrm{C}$ (CLAMP), 5-13.3 ${ }^{\circ} \mathrm{C}$ (CA); and MAP: 1003-1613 mm (CA) - see detailed in Tables 2, 3. The results of LMA from Český Chloumek, Haselbach and Knau were excluded due to a low number of the evaluated taxa (from 9 to 13) which is also obvious from the values of the sampling errors (SE 1, SE 2) exceeding $3.9^{\circ} \mathrm{C}$ (Table 2). However, the used techniques have unequivocally proved a decreasing trend in the all studied palaeoclimatic parameters by the time of "the latest" flora of Roudníky (Fig. 13). An additional palaeoclimatic parameter, the mean annual range of temperature (MART), based on the CLAMP proxies, arose from $14.6^{\circ} \mathrm{C}$ (floras of the Zeitz floristic assemblage) and/or $19.6{ }^{\circ} \mathrm{C}$ (Staré Sedlo) to $21.6{ }^{\circ} \mathrm{C}$ (Roudníky) and based on the CA estimates increased from $14.3{ }^{\circ} \mathrm{C}$ (Knau) and/or $18.1{ }^{\circ} \mathrm{C}$ (Staré Sedlo) to $19.5^{\circ} \mathrm{C}$ (Roudníky). Mosbrugger et al. (2005) published CA proxy-datasets for the flora of Böhlen 
(Weisselster Basin, Saxony, $37 \mathrm{Ma}$ ) showing well comparable estimates with Roudníky (Table 3). However, the CA analysis is based on only 9 taxa and the floristic characters of Böhlen and Roudníky do not correspond (see above).

The studied palaeoclimatic proxy-datasets derived from the early Oligocene assemblages/sites in the Bohemian Massif and Saxony show only a slightly different character comparing to Roudníky (see Tables 2, 3). The palaeoclimatic proxy-datasets derived by CA for probably the oldest early Oligocene flora of Valeč in the Bohemian Massif has a very approximate value due to the long range of the CA intervals (exceeded $10{ }^{\circ} \mathrm{C}$ by MAT and CMMT parameters). But it also shows a significant decreasing trend of temperature in comparison to the above mentioned late Eocene floras, e.g., differences of MAT are $4.3{ }^{\circ} \mathrm{C}$ higher (Staré Sedlo), $3.7{ }^{\circ} \mathrm{C}$ (Haselbach), and $0.3{ }^{\circ} \mathrm{C}$ (Roudníky). The mean value of MAT proxy-data at Valeč $\left(15.5^{\circ} \mathrm{C}\right)$ seems to be very low comparing those to the average value of MAT $\left(17.7^{\circ} \mathrm{C}\right)$ estimated for Haselbach, Regis and Beucha (Table 3) and/or Bechlejovice and Kundratice $\left(16.0{ }^{\circ} \mathrm{C}\right.$ and $\left.16.6{ }^{\circ} \mathrm{C}\right)$. The presented palaeoclimatic proxy-datasets of Roudníky estimated by the LMA, CA and CLAMP techniques correspond in all studied parameters to those of the early Oligocene sites of Bechlejovice, Kundratice, Beucha, Regis, Haselbach, Hammerunterwiesenthal, Holý Kluk, and Seifhennersdorf rather than to those from the studied late Eocene sites from the Bohemian Massif and Saxony (Tables 2, 3; Fig. 13). The averaged values of the important palaeoclimatic parameters of the mentioned early Oligocene sites summarizing LMA, CLAMP and CA estimates (Tables 2,3) are characterized as follows, i.e., MAT: $13.7^{\circ} \mathrm{C}\left(\mathrm{LMA}_{\mathrm{MAT}}\right)$, $12.1{ }^{\circ} \mathrm{C}\left(\mathrm{LMA}_{\text {MAT } 2}\right), 11.3{ }^{\circ} \mathrm{C}$ (CLAMP), $17.1^{\circ} \mathrm{C}(\mathrm{CA})$; WMMT: $22.7^{\circ} \mathrm{C}$ (CLAMP), $26{ }^{\circ} \mathrm{C}$ (CA); CMMT: $1.2{ }^{\circ} \mathrm{C}$ (CLAMP), $8.3{ }^{\circ} \mathrm{C}$ (CA); and MAP: 1182 (CA). Kvaček \& Walther (2004) published palaeoclimatic estimates for Bechlejovice derived from CLAMP and CA. These original values show warmer characteristics and are here reevaluated using extended NLR's database (CA) as well as the gridded meteorological calibration datasets (Table 3).

Zachos et al. $(2001,2008)$ characterized palaeoclimatically the Eocene epoch as follows: It starts by a significant peak of the Early Eocene Climatic Optimum (EECO; 52 to $50 \mathrm{Ma}$ ) expressed by a $1.5 \%$ o decrease in $\delta^{18} \mathrm{O}$. This event was followed by a $17 \mathrm{Ma}$ long trend towards cooler conditions (3.0\% rise in $\delta^{18} \mathrm{O}$ ), with much of the change occurring during the early-middle Eocene (50 to $48 \mathrm{Ma}$ ) into the early Oligocene ( 35 to $34 \mathrm{Ma}$ ). The cooling trend is also proved in terrestrial ecosystems by the presented changes in palaeovegetation and palaeoclimate during the late Eocene and/or on the boundary of late Eocene/early Oligocene (Tables 1-3; Fig. 13) in the Bohemian Massif (Staré Sedlo, Kučlín, Roudníky) as well as in Saxony (Knau, Haselbach, Böhlen see Mosbrugger et al. 2005, Figs 2, 3).
Palaeoclimatic studies of this time interval from other parts of the Northern Hemisphere are partly contradictory. The terrestrial spore and pollen assemblages recovered in the Norwegian-Greenland Sea indicate at the Eocene-Oligocene transition increased seasonality and the shift to cooler winters (Eldrett et al. 2009). European climatic proxies derived from the terrestrial records are regionally heterogene (Hren et al. 2013). Climatic characters of vegetation boundaries changed in Europe with the palaeogeographical position and influence of oceanic $v s$. continental climate (Kvaček 2010). The different signals of terrestrial plant fossils and fish fauna/radiometric dating in the area of Roudníky and Větruše may reflect environmental conditions on the land due to volcanic activities, transport from the vegetation cover at higher altitudes or even atmospheric "cooling" effect of volcanic activity. We favour the explanation by an increased seasonality of climate, as suggested for high latitude Europe (Eldrett et al. 2009), which allows for overrepresentation of deciduous over evergreen and more sensitive plant elements.

\section{Conclusions}

1. Concerning the floristic composition, the floras of Roudníky and Větruše are closer to those of early Oligocene age known from adjacent areas. They both widely deviate from those of the late Eocene (Kučlín). This floristic difference may not be so strongly expressed in their leaf physiognomy. On the contrary, the fish fauna includes Cyclurus typical of the European Eocene, which is in line with the radiometric dating of adjacent basalts.

2. Based on the megafossil flora and fish fauna of Roudníky and Větruše, the major turnover in ecosystems from subtropical to warm temperate climatic regimes in North Bohemia is to be placed as early as within the late Eocene pending the radiometric datation is correct. The increased seasonality of climate may have played a more important role than the drop of mean annual temperature.

3. According to the results of IPR-vegetation analysis corroborated by cluster analysis (Ward's method, Euclidean square distance), the vegetation type of Roudníky shows the closest affinity to early Oligocene vegetation of Bechlejovice and late Eocene vegetation of Kučlín, as well as to modern MMF vegetation classified to the association of Eurya-Cryptomeria japonica from the Yakushima Island (Japan). The cluster analysis proves a close relationship of Roudníky (as well as Kučlín) to early Oligocene sites rather than the late Eocene sites from the Staré Sedlo Formation and the Weisselster Basin. 
4. The higher value of \% SCL+LEG components in Roudníky (Gleditsia sp., Mimosites haeringianus, Pyracantha kraeuselii, Ziziphus ziziphoides) should indicate "more open" upland vegetation (light forest). It corresponds also to relatively low values of $\mathrm{SH}, \mathrm{RH}, \mathrm{MAP}$ contrary to those estimated for the other studied late Eocene sites of the Staré Sedlo Formation and the Weisselster Basin.

5. The vegetation change, which is expressed by drastically decreased proportion of BLE and increase of BLD elements at Roudníky (as detected by phytosociological approach and IPR-vegetation analysis) during the latest Eocene in the Bohemian Massif, corresponds to a significant cooling trend of wintermean temperatures, independently proven by LMA, CLAMP, CA and geochemical techniques.

6. Palaeoclimatic estimates of Roudníky are best comparable to those of the studied early Oligocene sites rather than to late Eocene palaeoclimatic proxy-datasets of the Staré Sedlo Formation and the Weisselester Basin.

\section{Acknowledgment}

This publication has been produced with help of the curators of the collections housed in the National Museum in Prague and Regional Museum, Teplice, who kindly provided access and also technically supported this study by facilitating microscopy. We thank to Torsten Utescher (Bonn), who kindly supplied palaeoclimatic proxy datasets based on the Coexistence Approach, and Magda Konzalová (Prague), who provided information on palynology. Greatly appreciated are also the suggestions and notes made on the first version of the manuscript by the reviewers Steven R. Manchester and Jakub Sakala. The study was financially supported by the Ministry of Education, Youth and Sports of the Czech Republic, i.e., grant projects J 13/98: 113100006 and MSM 002162085, and the grant project GA CR No. $\mathrm{P} 210 / 10 / 0124$ and 14-23108S. The paper is also a contribution to the NECLIME international project (www.neclime.de).

\section{References}

ADAMs, R.P. 2008. Junipers of the World. The genus Juniperus. $2^{\text {nd }}$ ed. 402 pp. Trafford publishing, Victoria, British Columbia.

Agassiz, L. 1833-1844. Recherches sur les Poissons Fossiles. 1420 pp. Petitpierre, Neuchatel.

Akhmetiev, M., Walther, H. \& Kvaček, Z. 2009. Mid-latitude Palaeogene floras of Eurasia bound to volcanic settings and palaeoclimatic events - experience obtained from the Far East of Russia (Sikhote-Alin') and Central Europe (Bohemian Massif). Acta Musei nationalis Pragae, Series B - historia naturalis 65(3-4), 61-129.

Bellon, H., BưŽEK, Č., Gaudant, J., KvaČEK, Z. \& Walther, H. 1998. The České středohoří magmatic complex in Northern
Bohemia ${ }^{40} \mathrm{~K}-{ }^{40}$ Ar ages for volcanism and biostratigraphy of the Cenozoic freshwater formations. Newsletters on Stratigraphy 36, 77-103.

Bevelander, G. 1934. The Gills of Amia calva Specialized for Respiration in an Oxygen Deficient Habitat. Copeia 1934, 123-127. DOI 10.2307/1436756

BöHme, M. 2007. Revision of the cyprinids from the Early Oligocene of the České středohoří Mountains, and the phylogenetic relationships of Protothymallus Laube 1901 (Teleostei, Cyprinidae, Gobioninae). Acta Musei nationalis Pragae, Series B - historia naturalis 63, 175-194.

Bonaparte, C.L. 1831-1832. Saggio di una distribuzione metodica degli animali vertebrati. Prospetto del sistema generale d'Ittiologia. Giornale Arcadico di Scienze Lettere ed Arti 52, 155-189.

Bonaparte, C.L. 1846. Catalogo metodico dei pesci europei. Atti della Settima Adunanza degli Scienziati Italiani, Napoli, Part 2, 1-95.

Brongniart, A. 1828. Notice sur les plantes d'Armissan près Narbonne. Annales des Sciences Naturelles, Botanique, Série $1,15,43-51$.

BronN, H.G. 1838. Lethaea geognostica 2. 543-1346 pp. E. Schweizerbart's Verlagshandlung, Stuttgart.

Brown, R.W. 1935. Miocene leaves, fruits and seeds of Cercidiphyllum. Journal of Paleontology 13, 485-499.

Budantsev, L.Y. \& Golovneva, L.B. 2009. Fossil flora of Arctic II. Paleogene Flora of Spitsbergen. 400 pp. Marafon, Sankt Peterburg.

BưŽEK, Č. 1967. Paleontologické výzkumy terciéru na území M-3-53-A Ústí nad Labem. MS Geofond, P 19929/16, Praha.

BưžEK, Č. 1971. Tertiary flora from the northern part of the Pětipsy area (North-Bohemian Basin). Rozpravy Ústředního ústavu geologického 36(1), 1-118.

BưžEK, Č. 1990. Výsledky provedeného výzkumu ÚÚG Praha, Paleontologie terciéru, 8-21. In VÁCha, J., Martinovská, I., Zelenka, O., Berka, S. \& Havrlík, S. (eds) Výpočet zásob hnědého uhlí lomu Chabařovice II. MS VGP Osek.

BưžEK, Č. 1991. Paleontologické výzkumy terciéru na území listu Ústí nad Labem. Zprávy o geologických výzkumech v roce 1989, 29-31.

Bưžek, Č., Čtyroký, P., Fejfar, O. \& KvaČek, Z. 1987. Přínos paleontologie pro poznání severočeské pánve, 70-87. In BRUS, Z., Elznic, A., Hurník, S. \& Zelenka, O. (eds) Geologie oblasti, XXVI. celostátní konference ČSMG. Most.

BưžEK, Č., Fejfar, O., KonZalová, M., \& KvaČEK, Z. 1990. Floristic changes around Stehlin's Grande Coupure, 167-181. In Knobloch, E. \& KvaČex, Z. (eds) Proceedings of the Symposium Palaeofloristic and Palaeoclimatic changes in the Cretaceous and Tertiary, Prague 1989. Geological Survey, Prague.

BưŽEK, Č., HolÝ, F. \& KvAČEK, Z. 1967. Eine bemerkenswerte Art der Familie Platanaceae Lindl. (1836) im nordböhmischen Tertiär. Monatsberichte der Deutschen Akademie der Wissenschaften zu Berlin 9, 203-215.

Bưžek, Č., Holý, F. \& Kvaček, Z. 1968. Die Gattung Doliostrobus Marion und ihr Vorkommen im nordböhmischen Tertiär. Palaeontographica, Abteilung B 123, 153-172.

BưžEK, Č., Holý, F. \& KvaČEK, Z. 1976. Tertiary flora from Volcagenic Series at Markvartice and Veselíčko near Česká 
Kamenice (České středohoří Mts.). Sborník Ústředního ústavu geologického, Paleontologie 18, 69-132.

ČADeK, J., ČADKovÁ, Z. \& DušEK, P. 1990. Výsledky provedeného výzkumu ÚÚG Praha, Geochemický výzkum, 75-105. In Vácha, J., Martinovská, I., Zelenka, O., Berka, S. \& HAVRLín, S. (eds) Výpočet zásob hnědého uhlí lomu Chabarovice II. MS VGP Osek.

CAJZ, V. 1990. Výsledky provedeného výzkumu ÚÚG Praha, Podpánevní vulkanický komplex, 31-37. In VÁCHA, J., MARTINOVSKÁ, I., Zelenka, O., Berka, S. \& HaVRLíK, S. (eds) Výpočet zásob hnědého uhlí lomu Chabařovice II. MS VGP Osek.

CAJz, V. 1999. The České středohoří Mts.: Volcanostratigraphy and geochemistry. Geolines 9, 21-28.

CAJZ, V. 2000. Proposal of lithostratigraphy for the České středohoří Mts. volcanics. Věstník Českého geologického ústavu 75(1), 7-16.

Chang, M. \& Chen, Y.Y. 2000. Late Mesozoic and Tertiary ichthyofaunas from China and some puzzling patterns of distribution. Vertebrata PalAsiatica 38(3), 161-175.

Christenhusz, M.J.M., Reveal, J.L., FArJon, A., Gardner, M.F. Mill, R.R. \& CHASE, M.W. 2011. A new classification and linear sequence of extant gymnosperms. Phytotaxa 19, 55-70.

Collinson, M.E. 1980. Recent and Tertiary seeds of the Nymphaeaceae sensu lato with a revision of Brasenia ovula (Brongn.) Reid et Chandler. Annals of Botany 46, 603-612.

Collinson, M.E. 1992. Vegetational and floristic changes around the Eocene-Oligocene boundary in western and Central Europe, 437-450. In Prothero, D.R. \& Berggren, W.A. (eds) Eocene-Oligocene climatic and biotic evolution. Princeton University Press, Princeton.

Collinson, M.E., Manchester, S.R., Wilde, V. \& Hayes, P. 2010. Fruit and seed floras from exceptionally preserved biotas in the European Paleogene. Bulletin of Geosciences 85(1), 155-162. DOI 10.3140/bull.geosci.1155

DomÁCí, L. 1977. Litostratigrafie třetihorních sedimentů v hnědouhelné severočeské pánvi. Acta Universitatis Carolinae, Geologica 1975(1), 75-80.

Eldrett, J.S., Greenwood, D.R., Hardin, I.C. \& Huber, M. 2009. Increased seasonality through the Eocene to Oligocene transition in northern high latitudes. Nature 459, 969-973. DOI 10.1038/nature08069

Ettingshausen, C. v. 1853. Die fossile Flora von Häring in Tirol. Abhandlungen der Kaiserlich-königlichen Geologischen Reichsanstalt 2(2), 1-118.

Ettingshausen, C. v. 1868. Die fossile Flora des Tertiärbeckens von Bilin, II. Denkschriften der kaiserlichen Akademie der Wissenschaften, mathematisch-naturwissenschaftliche Klasse 28, 191-242.

Ettingshausen, C. v. 1869. Die fossile Flora des Tertiärbeckens von Bilin, III. Denkschriften der kaiserlichen Akademie der Wissenschaften, mathematisch-naturwissenschaftliche Klasse 29, 1-110.

Frankenhäuser, H. \& WiLde, V. 1995. Stachelspitzige Blätter aus dem Mitteleozän von Eckfeld (Eifel). Abhandlungen des Staatlichen Museums für Mineralogie und Geologie zu Dresden 41, 97-115.

Gaudant, J. 1988. L'ichthyofaune Éocéne de Messel et du Geiseltal (Allemagne): essai d'approche paléobiogéographique. Courier Forschungsinstitut Senckenberg 107, 355-367.
Gaudant, J. 2008. Complements to the anatomical knowledge of Cyclurus macrocephalus Reuss (Pisces, Actinopterygii) from the Eocene of Kučlín, Bohemia, Czech Republic. Acta Musei nationalis Pragae, Series $B$ - historia naturalis 64, 3-7.

GaUdANT, J. 2012. An attempt at the palaeontological history of the European mudminnows (Pisces, Teleostei, Umbridae). Neues Jahrbuch für Geologie und Paläontologie, Abhandlungen 263, 93-109. DOI 10.1127/0077-7749/2012/0214

Gaudant, J. \& Meunier, F. 2004. Un test pour déterminer la position systématique du genre Thaumaturus Reuss (poisson téléostéen): l'approche paléohistologique. Courier Forschungsinstitut Senckenberg 252, 79-93.

Geyer, F. \& Mann, H. 1939a. Beiträge zur Atmung der Fische I. Die Atmung des Ungarischen Hundsfisches (Umbra lacustris Grossinger). Zoologischer Anzeiger 127, 234-245.

Geyer, F. \& MANN, H. 1939b. Beiträge zur Atmung der Fische II. Weiteres zur Atmung des Ungarischen Hundsfisches (Umbra lacustris Grossinger). Zoologischer Anzeiger 127, 305-312.

Graham, A. 1999. Late Cretaceous and Cenozoic history of North American vegetation north of Mexico. $350 \mathrm{pp}$. Oxford University Press, New York \& Oxford.

Grande, L. \& Bemis, W.E. 1998. A comprehensive phylogenetic study of amiid fishes (Amiidae) based on comparative skeletal anatomy. An empirical search for interconnected patterns of natural history. Society of Vertebrate Paleontology Memoir 4, 1-681. DOI 10.2307/3889331

Guo, S.X., Kvaček, Z., Manchester, S. R. \& Zhou, Z.K. 2012. Foliage and seed cones of the extinct genus Ditaxocladus (Cupressaceae) from the Upper Cretaceous to Paleocene of Asia and North America. Palaeontographica, Abteilung B, 288(5-6), 135-159.

Guo, S.X. \& Zhоu, Z.K. 1992. The megafossil legumes from China, 207-223. In Herendeen, P.S. \& Dilcher, D.L. Advances in legume systematics, part. 4. Fossil record. The Royal Botanic Gardens, Kew.

HaBLY, L. 1985. Catalogue of the Hungarian Cenozoic leaf-flora. Studia Botanica Hungarica 18, 5-58.

HAY, O. 1929. Second bibliography and catalogue of the fossil Vertebrata of North America. Publications of the Carnegie Institute of Washington 390, 1-2003.

He, J., Chen, W., Xie, Z. \& Hu, D. 1998. Types of the evergreen broad-leaved forest and their community species diversity in Longqishan Nature Reserve, Fujian Province. Chinese Journal of Ecology 1998, 17(3), 1-6.

HeER, O. 1853. Übersicht der Tertiärflora der Schweiz. Mitteilungen der Naturforschenden Gesellschaften 3(7), 88-153.

HeER, O. 1856. Flora Tertiaria Helvetiae II. 110 pp. J. Wurster et comp., Winterthur.

HeER, O. 1859. Flora Tertiaria Helvetiae III. 378 pp. J. Wurster et comp., Winterthur.

HeER, O. 1869. Miozäne baltische Flora. Beiträge zur Naturkunden Preussens 2, 1-104.

Holý, F., Kvaček, Z. \& TeOdoridis, V. 2012. A review of the Early Miocene maastixioid flora of the Kristina mine at Hrádek nad Nisou in North Bohemia (the Czech Republic). Acta Musei nationalis Pragae, Series B - historia naturalis 68(3-4), 53-118.

Hren, M.T., Sheldon, N.D., Grimes, S.T., Collinson, M.E., 
Hooker, J.J., Bugler, M. \& Lohmann, K.C. 2013. Terrestrial cooling in Northern Europe during the Eocene-Oligocene transition. PNAS Early Edition.

DOI 10.1073/pnas.1210930110

JIRÁNEK, J. et al. 1990. Základní geologická mapa ČSFR 1 : 25000 list 02-322 Krupka. Ústřední ústav geologický, Praha.

Judd, W.S., Campbell, C.S., KellogG, E.A., Stevens, P.F. \& Donoghue, M.J. 2002. Plant systematics. A phylogenetic approach. Second Edition. 576 pp. Sinauer Associates, Sunderland, Massachusetts.

KatZ, M.E., Miller, K.G., Wright, J.D., Wade, B.S., Browning, J.V., Cramer, B.S. \& Rosenthal, Y. 2008. Stepwise transition from the Eocene greenhouse to the Oligocene icehouse. Nature Geoscience 1, 329-334.

KirchHeIMER, F. 1937. Paläobotanische Beiträge zur Kenntnis des Alters deutscher Braunkohlenschichten. II. Braunkohle 36, 893-931.

KNobloch, E. 1961. Die oberoligozäne Flora des Pirskenberges bei Šluknov in Nord-Böhmen. Sborník Ústředního ústavu geologického, Paleontologie 26, 241-315.

Knobloch, E., Konzalová, M. \& KvaČEK, Z. 1996. Die obereozäne Flora der Staré Sedlo - Schichtenfolge in Böhmen (Mitteleuropa). Rozpravy Českého geologického ústavu 49, $1-260$.

KNobloch, E. \& KvaČEK, Z. 1976. Miozäne Blätterfloren vom Westrand der Böhmischen Masse. Rozpravy Ústředního ústavu geologického 42, 1-31.

KonZALOVÁ, M. 1989. Mikropaleontologický (palynologický) výzkum sedimentů vulkanického komplexu na jižním okraji severočeské pánve u Modlan. Zprávy o geologických výzkumech $v$ roce $1987,72-74$.

KonZalovÁ, M. 2003. Volcanosedimentary complex of the České středohoří and Doupovské hory Mts. in palynological records. Geolines 15, 52-59.

Kotlaba, F. 1963. Tertiary plants from three localities in southern Slovakia. Sborník Národního muzea, Řada B 19, 53-72.

Kovar-Eder, J., Jechorek, H., Kvaček, Z. \& Parashiv, V. 2008. The Integrated Plant Record: an essential tool for reconstructing Neogene zonal vegetation in Europe. Palaios 23, 97-111. DOI 10.2110/palo.2006.p06-039r

Kramer, J.A. in Scopoli, J.A. 1777. Introductio ad historiam naturalem, sistens genera lapidum, plantarum et animalium hactenus detecta, caracteribus essentialibus donata, in tribus divisa, subinde ad leges naturae. 506 pp. Prague.

Kunzmann, L. 1999. Koniferen der Oberkreide und ihre Relikte im Tertiär Europas. Abhandlungen des Staatlichen Museums für Mineralogie und Geologie zu Dresden 45, 5-135.

Kunzmann, L., Kvaček, Z., Mai, D.H. \& Walther, H. 2009. The genus Taxodium (Cupressaceae) in the Palaeogene and Neogene of Central Europe. Review of Palaeobotany and Palynology 153, 153-183.

DOI 10.1016/j.revpalbo.2008.08.003

KvAČEK, Z. 1971. Fossil Lauraceae in the stratigraphy on the North Bohemian Tertiary. Sborník geologických věd, Paleontologie 13, 47-86.

KvaČEK, Z. 1984. Tertiary taxads of NW Bohemia. Acta Universitatis Carolinae, Geologica 1982(4), 471-491.

KvaČEK, Z. 1989. Fosilní Tetraclinis Mast. (Cupressaceae). Časopis Národního muzea, Řada př́rodovědná 155, 45-54.
KvaČEK, Z. 2002a. A new juniper from the Palaeogene of Central Europe. Feddes Repertorium 113, 492-502.

DOI 10.1002/fedr.200290001

KVAČEK, Z. 2002b. Late Eocene landscape, ecosystems and climate in north Bohemia with particular reference to the locality Kučlín near Bílina. Bulletin of the Czech Geological Survey 77, 217-236.

KvAČEK, Z. 2004a. Revisions to the Early Oligocene flora of Florsheim (Mainz Basin, Germany) based on epidermal anatomy. Senckenbergiana lethaea 84(1/2), 1-73.

KvAČEK, Z. 2004b. Early Miocene records of Craigia (Malvaceae s. 1.) in the Most Basin, North Bohemia - whole plant approach. Journal of Czech Geological Society 49(3-4), 161-171.

KVAČEK, Z. 2010. Forest flora and vegetation of the European early Palaeogene - a review. Bulletin of Geosciences 85(1), 3-16. DOI 10.3140/bull.geosci.1146

KvaČEK, Z., BöHme, M., DvoŘÁK, Z., KonZalová, M., MACH, K., PROKOP, J. \& RAJCHL, M. 2004. Early Miocene freshwater and swamp ecosystems of the Most Basin (north Bohemia) with particular reference to the Bílina Mine section. Journal of the Czech Geological Society 49(1-2), 1-40.

KvaČEK, Z., BưžEK, Č. \& MANCHESTER, S.R. 1991. Fossil fruits of Pteleaecarpum Weyland - tiliaceous, not sapindaceous. Botanical Gazette 152, 522-523. DOI 10.1086/337915

KVAČEK, Z. \& MANCHESTER, S.R. 2004. Vegetative and reproductive structure of the extinct Platanus neptuni from the Tertiary of Europe and relationships within the Platanaceae. Plant Systematics and Evolution 244, 1-29.

DOI 10.1007/s00606-003-0082-2

KvaČEK, Z., Manchester, S.R. \& Schorn, H.E. 2000. Cones, seeds, and foliage of Tetraclinis salicornioides (Cupressaceae) from the Oligocene and Miocene of western North America: a geographic extension of the European Tertiary species. International Journal of Plant Sciences 161(2), 331-344. DOI 10.1086/314245

KvaČEK, Z. \& TEODORIDIS, V. 2007. Tertiary macrofloras of the Bohemian Massif: a review with correlations within Boreal and Central Europe. Bulletin of Geosciences 82(4), 383-408. DOI 10.3140/bull.geosci.2007.04.383

KvaČEK, Z. \& TeOdoridis, V. 2011. The Late Eocene flora of Kučlín near Bílina in North Bohemia revisited. Acta Musei nationalis Pragae, Series B - historia naturalis 37(3-4), 83-144.

KvaČEK, Z. \& Walther, H. 1981. Studium über "Quercus" cruciata Al. Braun und analoge Blattformen aus dem Tertiär Europas. Acta Palaeobotanica 21(2), 77-100.

KvaČEK, Z. \& WALther, H. 1998. The Oligocene volcanic flora of Kundratice near Litoměřice, České středohoři volcanic complex (Czech Republic) - a review. Acta Musei nationalis Pragae, Series B - historia naturalis 54, 1-42.

KvaČEK, Z. \& Walther, H. 2001. The Oligocene of Central Europa and the development of forest vegetation in space and time based on megafossils. Palaeontographica, Abteilung $B$ 259, 125-149.

KvaČEK, Z. \& Walther, H. 2003. Reconstruction of vegetation and landscape development during the volcanic activity in the České středohoří Mountains. Geolines, Hibsch Special Volume 15, 60-64.

KvaČEK, Z. \& Walther, H. 2004. Oligocene flora of Bech- 
lejovice at Děčín from the neovolcanic area of the České středohoří Mountains, Czech Republic. Acta Musei nationalis Pragae, Series B - historia naturalis 60, 9-60.

KvaČEK, Z. \& Walther, H. 2012. European Tertiary Fagaceae with chinquapin-like foligae and leaf epidermal characteristics Feddes Repertorium 121(7-8, 2010), 248-267.

Li, Z.Y. \& SHI, L. 2007. Plants of Mount Emei. 492 pp. Beijing Science \& Technology Press, Beijing.

LORENZ, V. 2003. Maar-diatreme volcanoes, their formation, and their setting in hard-rock or soft-rock environments. Geolines $15,72-83$.

MAG, M. 1992. Petrologie vulkanitů. In VÁCHA, J., MartinovSKÁ, I., Zelenka, O., Berka, S. \& Havrlík, S. (eds) Výpočet zásob hnědého uhlí lomu Chabařovice II. MS VGP Osek.

MAI, D.H. 1963. Beiträge zur Kenntnis der Tertiärflora von Seifhennersdorf (Sachsen). Jahrbuch des Staatlichen Museums für Mineralogie und Geologie zu Dresden 1963, 39-114.

MAI, D.H. 1988. New Nymphealean fossils from the Tertiary of central Europe. Tertiary Research 9(1-4), 87-96.

MAI, D.H. 1995. Tertiäre Vegetationsgeschichte Europeas. 691 pp. Gustav Fischer Verlag, Jena, Stuttgart, New York.

MaI, D.H. \& Walther, H. 1978. Die Floren der Haselbacher Serie im Weisselster-Becken (Bezirk Leipzig, DDR). Abhandlungen des Museums für Mineralogie und Geologie zu Dresden 28, 1-200.

MaI, D.H. \& WALtheR, H. 1985. Die obereozänen Floren des Weisselsterbeckens und seiner Randgebiete. Abhandlungen des Staatlichen Museums für Mineralogie und Geologie zu Dresden 33, 1-260.

MaI, D.H. \& Walther, H. 2000. Die Fundstellen eozäner Floren des Weisselster-Beckens und seiner Randgebiete. Altenburger naturwissenschaftliche Forschungen 13, 1-59.

Martini, E. 1965. Die Fischfauna von Sieblos/Rhön(Oligozän). 2: Fischreste aus Koproliten. Senckenbergiana lethaea 46a, 307-314.

Micklich, N. 1988. Ergänzungen zur Morphologie und Systematik der Gattung Bilinia Obrhelová, 1971 (Pisces, Percoidei). Paläontologische Zeitschrift 62(3/4), 297-317.

Micklich, N. 1990. Ein neuer Percoide (Pisces, Perciformes) aus den tertiären Süßwasser-Diatomiten von Kuclin in Böhmen. Senckenbergiana lethaea 70(1/3), 199-208.

Micklich, N. \& BöHME, M. 1997. Wolfsbarsch-Funde (Perciformes, Moronidae) aus den Süßwasser-Diatomiten von Kuclín (Böhmen) nebst Anmerkungen zur taxonomischen Stellung von „Perca“ lepidota aus den Süßwasser-Kalken von Öhningen (Baden). Paläontologische Zeitschrift 71(1/2), $117-128$.

Miller, I.M., Brandon, M.T. \& Hickey, L.J. 2006. Using leaf margin analysis to estimate the mid-Cretaceous (Albian) paleolatitude of the Baja BC block. EPSL 245, 95-114.

Mosbrugger, V. \& Utescher, T. 1997. The coexistence approach - a method for quantitative reconstructions of Tertiary terrestrial palaeoclimate data using plant fossils. Palaeogeography, Palaeoclimatology, Palaeoecology 134, 61-86. DOI 10.1016/S0031-0182(96)00154-X

Mosbrugger, V., Utescher, T. \& Dilcher, D.L. 2005. Cenozoic continental climatic evolution of Central Europe. Proceedings of the National Academy of Sciences of the United States of America 102, 14964-14969.
Nelson, J.S. 1994. Fishes of the World. Third edition. 600 pp. John Wiley and Sons, New York.

ObrhelovÁ, N. 1971. Über einen Serranid (Pisces) aus dem nordböhmischen Süßwassertertiär. Časopis pro mineralogii a geologii 16(4), 371-387.

OBRHELOVÁ, N. 1975. Osteologischer Bau von Thaumaturus furcatus Reuss, 1844 (Pisces) aus dem nordböhmischen Süsswassertertiär (Kučlín bei Bílina). Časopis pro mineralogii a geologii 20(3), 273-290.

Obrhelová, N. 1976. Eine neue Percoiden-Art (Pisces) aus dem nordböhmischen Süßwassertertiär. Bemerkungen zur Gattung Bilinia Obrhelova, 1971. Časopis pro mineralogii a geologii 21(3), 233-256.

OBRHELOVÁ, N. 1978. Die Gattung Umbra Walbaum (Pisces) im Nordböhmischen Tertiär Entwicklungsgeschichte der Esocoidei Berg im Lichte der funktionalen Analyse. Sborník Národního muzea v Praze 34, 119-169.

ObrhelovÁ, N. 1990. Fische des Nordböhmischen Braunkohlenbeckens. Sborník Národního muzea v Praze 46, 1-35.

ObrhelovÁ, N. \& OBRHEL, J. 1987. Paläoichthyologie und Paläoökologie des kontinentalen Tertiärs und Quatärs der ČSSR. Zeitschrift für geologische Wissenschaften 15, 709-731.

Př́IKRYL, T. 2008. Sea bass fish Morone sp. (Teleostei) from North Bohemian Paleogene (Tertiary, Czech Republic). Bulletin of Geosciences 83(1), 117-122.

DOI 10.3140/bull.geosci.2008.01.117

PŘIKRYL, T. 2011. Lepidological review on the fish fauna of the Kučlín locality (Upper Eocene, Czech Republic). Acta Musei nationalis Pragae, Series B - historia naturalis 67, 149-156.

RADOŇ, M. 2001. Výzkum terciérních paleontologických lokalit v Českém středohoří. 380 pp. Závěrečná zpráva programového projektu Ministerstva kultury České republiky, Regionální muzeum v Teplicích.

RADOŇ, M., KvaČEK, Z. \& Walther, H. 2006. Oligocene megafossil plant remains and environment from the newly recovered locality of the Holý Kluk hill near Proboštov (České středohoří Mountains, Czech Republic). Acta Universitatis Carolinae, Geologica 47, 95-124.

ReID, E.M. \& Chander, M.E.J. 1926. Catalogue of Cainozoic plants in the Department of Geology. I. The Bembridge flora. 206 pp. British Museum (Natural History), London.

REVEAL, J.L. 2012. An outline of a classification system for extant flowering plants. Phytoneuron 2012(37), 1-221.

Roth-Nebelsick, A., Utescher, T., Mosbrugger, V., DiesterHaAss, L. \& Walther, H. 2004. Changes in atmospheric $\mathrm{CO}_{2}$ concentrations and climate from the Late Eocene to Early Miocene: palaeobotanical reconstruction based on fossil floras from Saxony, Germany. Palaeogeography, Palaeoclimatology, Palaeoecology 205(1-2), 43-67.

DOI 10.1016/j.palaeo.2003.11.014

SAPORTA, G. DE 1890. Revue des travaux de paléontologie végétale parus en 1888 ou dans le cours des années présédantes. Revue Générale de Botanique 2, 176-192, 225-239.

SAPORTA, G. DE \& MARion, A.F. 1876. Recherches sur les végétaux fossils de Meximieux. Archives du Museum d'Histoire Naturelle de Paris 1, 131-335.

Schultze, H.P. 1966. Morphologische Untersuchungen an Schuppen mesozoischer Actinopterygier (Übergang von 
Ganoid- zu Rundschuppen). Neues Jahrbuch für Geologie und Paläontologie, Abhandlungen 126, 232-314.

Spicer, R.A., Valdes, P.J., Spicer, T.E.V., Craggs, H.J., Srivastava, G., Mehrotra, R.C. \& Yang, J. 2009. New development is CLAMP: calibration using global gridded meteorological data. Palaeogeography, Palaeoclimatology, Palaeoecology 283, 91-98. DOI 10.1016/j.palaeo.2009.09.009

Stur, D. 1867. Beiträge zur Kenntnis der Flora der Süßwasserquarzite, der Congerien- und Cerithien-Schichten im Wiener und ungarischen Becken. Jahrbuch der Geologischen Reichsanstalt 17(1), 77-188.

Su, T., Xing, Y.W., Liu, Y.S, Jacques, F.M.B., Chen, W.Y., HuANG, Y.J. \& ZHou, Z.K. 2010. Leaf margin analysis: a new equation from humid to mesic forests in China. Palaios 25, 234-238. DOI 10.2110/palo.2009.p09-129r

TANG, C.Q., LI, T. \& Zhu, X. 2007. Structure and regeneration dynamics of free subtropical midmontane moist evergreen broad-leaved forests in southwestern China with special reference to bamboo in the forest understories. Canadian Journal of Forest Research 37, 2701-2714. DOI 10.1139/X07-101

TANG, C.Q. \& OHSAWA, M. 1997. Zonal transition of evergreen, deciduous and coniferous forests along the altitudinal gradient on a humid subtropical mountain, Mt. Emei, Sichuan, China. Plant Ecology 133, 63-78. DOI 10.1023/A:1009729027521

Teodoridis, V. Kovar-Eder, J., Marek, P., Kvaček, Z. \& Mazouch, P. 2011a. The Integrated Plant Record vegetation analysis - a new on-line application. Acta Musei nationalis Pragae, Series B - historia naturalis 37(3-4), 159-165.

Teodoridis, V., Kovar-Eder, J. \& Mazouch, P. 2011b. The IPR-vegetation analysis applied to modern vegetation in SE China and Japan. Palaios 26(10), 623-638.

DOI 10.2110/palo.2010.p10-149r

Teodoridis, V., KvaČek, Z., Zhu, H. \& Mazouch, P. 2012. Vegetational and environmental analysis of the mid-latitudinal European Eocene sites and their possible analogues in Southeastern Asia. Palaeogeography, Palaeoclimatology, Palaeoecology 333-334, 40-58.

DOI 10.1016/j.palaeo.2012.03.008

Teodoridis, V., Mazouch, P. Spicer, R.A. \& Uhl, D. 2011c. Refining CLAMP - investigations towards improving the Climate Leaf Analysis Multivariate Program. Palaeogeography, Palaeoclimatology, Palaeoecology 299(1-2), 39-48. DOI 10.1016/j.palaeo.2010.10.031

UnGER, F. 1841-1847. Chloris protogaea 1-10. 149 pp. W. Engelmann, Leipzig.

UNGER, F. 1850. Genera et species plantarum fossilium. 627 pp. W. Braunmüller, Vindobonae.

Utescher, T., Mosbrugger, V. \& Ashraf, A.R. 2000. Terrestrial climate evolution in Northwest Germany over the last 25 million years. Palaios 15, 430-449.

DOI 10.1669/0883-1351(2000)015<0430:TCEING>2.0.CO;2

VÁcha, J., MartinovsKá, I., Zelenka, O., Berka, S. \& Havrlík, S. 1992. Výpočet zásob hnědého uhli lomu Chabařovice II. Textová část. MS VGP Osek.
Walther, H. 1972. Studien über tertiäre Acer Mitteleuropas. Abhandlungen des Museums für Mineralogie und Geologie zu Dresden 19, 1-309.

WaLther, H. 1998. Die Tertiärflora von Hammerunterwiesenthal (Freistaat Sachsen). Abhandlungen des Museums für Mineralogie und Geologie zu Dresden 43-44, 239-364.

Walther, H. 1999. Die Tertiärflora von Kleinsaubernitz bei Bautzen. Palaeontographica, Abteilung B 249, 61-174.

WAlther, H. \& KVAČEK, Z. 2007. Early Oligocene flora of Seifhennersdorf (Saxony). Acta Musei nationalis Pragae, Series $B$ - historia naturalis 63(2-4), 85-174.

WeYland, H. 1943. Beiträge zur Kenntnis der rheinischen Tertiärflora VI. Palaeontographica, Abteilung B 87, 96-136.

Weyland, H. \& KILPPER, K. 1963. Kritische Untersuchungen zur Kutikularanalyse Tertiärer Blätter. VI. Weitere Dikotyledonen aus der Rheinischen Braunkohle. Palaeontographica, Abteilung B 113, 93-116.

WiLDER, B.G. 1878. On the respiration of Amia. Proceedings of the American Association for the Advancement of Science 26, 306-313.

WILF, P. 1997. When are leaves good thermometers? A new case for leaf margin analysis. Paleobiology 23, 373-390.

Wolfe, J.A. 1979. Temperature parameters of the humid to mesic forests of eastern Asia and their relation to forests of other regions of the Northern Hemisphere and Australasia. United States Geological Survey Professional Paper 1106, $1-37$.

Wolfe, J.A. \& Schorn, H. 1990. Taxonomic revision of the Spermatopsida of the Oligocene Creede Flora, Southern Colorado. United States Geological Survey Bulletin 1923, $1-40$.

Wolfe, J.A. \& Spicer, R.A. 1999. Fossil leaf character states: multivariate analysis, 233-239. In JONES, T.P. \& RowE, N.P. (eds) Fossil Plants and Spores: Modern Techniques. Geological Society, London.

Wuttke, M., Přikryl, T., Ratnikov, V.Y., DvoR̆Ák, Z. \& RočEK, Z. 2012. Generic diversity and distributional dynamics of the Palaeobatrachidae (Amphibia: Anura). Palaeobiodiversity and Palaeoenvironments 92(2), 367-395. DOI 10.1007/s12549-012-0071-y

YANG, J., SPICER, R.A., SPICER, T.E.V. \& Li, C.S. 2011. 'CLAMP Online': a new web-based palaeoclimate tool and its application to the terrestrial Paleogene and Neogene of North America. Palaeobiodiversity and Palaeoenvironments 91, 163-183. DOI 10.1007/s12549-011-0056-2

Zachos, J.C., Dickens, G.R. \& ZeEbe, R.E. 2008. An early Cenozoic perspective on greenhouse warming and carbon-cycle dynamics. Nature 451(17), 279-283.

Zachos, J.C., Pegani, M., Stone, L., Thomas, E. \& Billups, K. 2001. Trends, rhythms, and aberrations in global climates 65 Ma to present. Science 292, 686-693.

DOI 10.1126/science.1059412

Zanazzi, A., Kohn, M.J., MacFadden, B.J. \& Terry, D.O. JR. 2007. Large temperature drop across the Eocene-Oligocene transition in central North America. Nature 445, 639-642. DOI 10.1038/nature05551 


\section{Appendix 1}

Percentages of foliar physiognomic characters of the studied floras.

\begin{tabular}{|c|c|c|c|c|c|c|c|c|}
\hline \multicolumn{2}{|l|}{ Foliar Physiognomic Characters [\%] } & 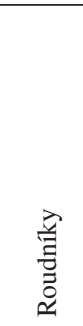 & 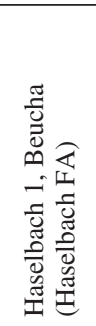 & 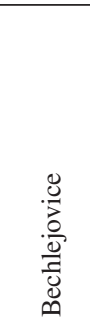 & 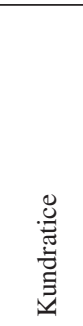 & 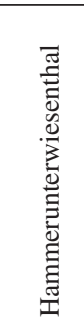 & $\begin{array}{l}\text { 首 } \\
\text { 齐 } \\
\text { 严 }\end{array}$ & 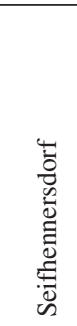 \\
\hline \multirow[t]{7}{*}{ Margin Character States } & Lobed & 15.63 & 25.00 & 19.23 & 11.48 & 20.00 & 15.38 & 16.33 \\
\hline & No Teeth & 26.56 & 40.00 & 30.77 & 41.80 & 53.85 & 30.77 & 38.78 \\
\hline & Teeth Regular & 46.88 & 47.50 & 47.12 & 38.52 & 23.08 & 55.77 & 28.57 \\
\hline & Teeth Close & 33.59 & 22.50 & 34.62 & 25.41 & 26.92 & 46.15 & 20.41 \\
\hline & Teeth Round & 27.34 & 27.50 & 24.04 & 15.57 & 0.00 & 36.54 & 14.29 \\
\hline & Teeth Acute & 45.31 & 37.50 & 47.12 & 42.62 & 38.46 & 40.38 & 47.96 \\
\hline & Teeth Compound & 10.94 & 7.50 & 6.73 & 10.66 & 0.00 & 3.85 & 11.22 \\
\hline \multirow[t]{9}{*}{ Size Character States } & Nanophyll & 0.00 & 0.00 & 0.00 & 0.00 & 0.00 & 0.00 & 0.00 \\
\hline & Leptophyll I & 0.00 & 0.00 & 0.00 & 0.00 & 0.00 & 1.92 & 0.00 \\
\hline & Leptophyll II & 3.13 & 0.00 & 1.92 & 3.28 & 11.36 & 5.77 & 0.00 \\
\hline & Microphyll I & 13.28 & 6.65 & 6.08 & 16.93 & 18.91 & 14.73 & 12.06 \\
\hline & Microphyll II & 35.78 & 28.70 & 28.46 & 33.05 & 46.18 & 54.46 & 29.22 \\
\hline & Microphyll III & 32.66 & 44.95 & 44.15 & 30.18 & 14.36 & 16.00 & 36.88 \\
\hline & Mesophyll I & 15.16 & 18.30 & 78.79 & 14.89 & 9.09 & 3.19 & 19.71 \\
\hline & Mesophyll II & 0.00 & 1.25 & 3.19 & 0.82 & 0.00 & 1.92 & 1.02 \\
\hline & Mesophyll III & 0.00 & 0.00 & 0.00 & 0.82 & 0.00 & 1.92 & 1.02 \\
\hline \multirow[t]{4}{*}{ Apex Character States } & Apex Emarginate & 0.63 & 0.00 & 0.00 & 0.00 & 0.00 & 46.15 & 1.69 \\
\hline & Apex Round & 25.09 & 10.00 & 11.54 & 25.67 & 0.00 & 38.46 & 14.96 \\
\hline & Apex Acute & 44.31 & 45.00 & 61.54 & 49.44 & 66.67 & 59.62 & 44.55 \\
\hline & Apex Attenuate & 29.94 & 45.00 & 26.92 & 24.85 & 33.33 & 1.92 & 38.78 \\
\hline \multirow[t]{3}{*}{ Base Character States } & Base Cordate & 10.94 & 9.15 & 22.12 & 11.48 & 54.17 & 19.23 & 19.71 \\
\hline & Base Round & 37.50 & 31.65 & 37.50 & 30.33 & 12.50 & 57.69 & 35.02 \\
\hline & Base Acute & 51.56 & 59.15 & 39.42 & 58.20 & 33.33 & 23.08 & 45.22 \\
\hline \multirow[t]{5}{*}{ Length to Width Character States } & $\mathrm{L}: \mathrm{W}<1: 1$ & 4.69 & 6.25 & 3.85 & 5.74 & 4.55 & 19.23 & 9.18 \\
\hline & $\mathrm{L}: \mathrm{W} 1-2: 1$ & 17.97 & 13.75 & 26.92 & 18.85 & 43.91 & 25.00 & 18.37 \\
\hline & $\mathrm{L}: \mathrm{W} 2-3: 1$ & 30.16 & 27.50 & 25.63 & 30.87 & 16.64 & 25.00 & 26.51 \\
\hline & L : W 3-4 : 1 & 37.03 & 25.00 & 33.33 & 34.97 & 34.82 & 13.46 & 29.57 \\
\hline & $\mathrm{L}: \mathrm{W}>4: 1$ & 10.16 & 25.00 & 10.25 & 9.56 & 0.00 & 17.31 & 16.31 \\
\hline \multirow[t]{3}{*}{ Shape Character States } & Obovate & 0.63 & 2.50 & 1.60 & 2.46 & 0.00 & 15.38 & 2.04 \\
\hline & Elliptic & 33.59 & 40.00 & 33.33 & 54.92 & 83.33 & 34.62 & 31.63 \\
\hline & Ovate & 65.78 & 57.50 & 65.06 & 42.62 & 16.67 & 50.00 & 66.33 \\
\hline
\end{tabular}




\section{Appendix 2A}

List of plant taxa occurring in the studied floras from Roudníky and their scoring according to the IPR-vegetation analysis.

\begin{tabular}{|c|c|c|c|c|c|c|c|c|c|c|c|c|c|c|}
\hline site: Roudníky & & & & $\mathrm{ZOI}$ & & & & & & & ZONAL & & & \\
\hline Taxa & 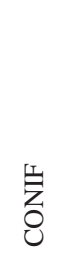 & $\stackrel{\oplus}{\oplus}$ & 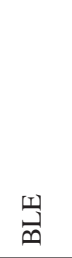 & $\vec{U}$ & 亗 & 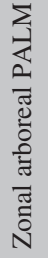 & 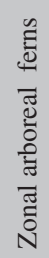 & 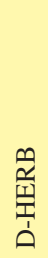 & 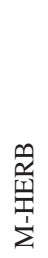 & 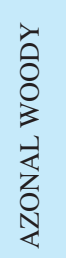 & 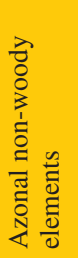 & 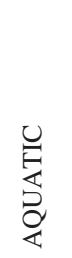 & 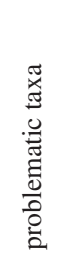 & 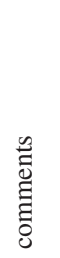 \\
\hline Acer augustilobum & & 1.00 & & & & & & & & & & & & 1.00 \\
\hline Acer cf. tricuspidatum & & 0.25 & & & & & & & & 0.75 & & & & 1.00 \\
\hline Acer palaeosaccharium & & 1.00 & & & & & & & & & & & & 1.00 \\
\hline Alnus gaudinii / A. kefersteinii & & 1.00 & & & & & & & & & & & & 1.00 \\
\hline Betula alnoides / B. dryadum & & 1.00 & & & & & & & & & & & & 1.00 \\
\hline cf. Sabrenia sp. & & & & & & & & & & & & 1.00 & & 1.00 \\
\hline Carpinus sp. / C. mediomontana & & 1.00 & & & & & & & & & & & & 1.00 \\
\hline Carpolithes sp. & & & & & & & & & & & & & 1.00 & 1.00 \\
\hline Carya fragiliformis & & 1.00 & & & & & & & & & & & & 1.00 \\
\hline cf. Cephalotaxus parvifolia & 1.00 & & & & & & & & & & & & & 1.00 \\
\hline Cercidiphyllum crenatum & & 0.25 & & & & & & & & 0.75 & & & & 1.00 \\
\hline Craigia bronii / Dombeyopsis lobata & & 0.50 & & & & & & & & 0.50 & & & & 1.00 \\
\hline Crategus pirskenbergensis & & 1.00 & & & & & & & & & & & & 1.00 \\
\hline Cyclocarya sp. & & 1.00 & & & & & & & & & & & & 1.00 \\
\hline Dicotylophyllum deichmuelleri & & & 1.00 & & & & & & & & & & & 1.00 \\
\hline Diospyros sp. & & 1.00 & & & & & & & & & & & & 1.00 \\
\hline Fraxinus sp. & & 0.50 & & & & & & & & 0.50 & & & & 1.00 \\
\hline Gleditsia sp. & & & & 0.50 & 0.50 & & & & & & & & & 1.00 \\
\hline Juniperus pauli & 1.00 & & & & & & & & & & & & & 1.00 \\
\hline Laurophyllum acutimontanum & & & 1.00 & & & & & & & & & & & 1.00 \\
\hline Laurophyllum pseudoprinceps & & & 1.00 & & & & & & & & & & & 1.00 \\
\hline Leguminosites sp. & & & & & 1.00 & & & & & & & & & 1.00 \\
\hline Liriodendron haueri & & 1.00 & & & & & & & & & & & & 1.00 \\
\hline cf. Matudaea menzelii & & & 1.00 & & & & & & & & & & & 1.00 \\
\hline Tilia brassicoides & & 1.00 & & & & & & & & & & & & 1.00 \\
\hline Mimosites haeringianus & & & & & 1.00 & & & & & & & & & 1.00 \\
\hline Nyssa disseminata & & 0.50 & & & & & & & & 0.50 & & & & 1.00 \\
\hline Ostrya atlantidis & & 1.00 & & & & & & & & & & & & 1.00 \\
\hline Paleolobium sp. & & 0.50 & 0.50 & & & & & & & & & & & 1.00 \\
\hline Pinus sp. & 1.00 & & & & & & & & & & & & & 1.00 \\
\hline Platanus neptuni & & 0.50 & & & & & & & & 0.50 & & & & 1.00 \\
\hline Pungiphyllum cruciatum & & & 1.00 & & & & & & & & & & & 1.00 \\
\hline Pyracantha kraeuselii & & & 0.50 & 0.50 & & & & & & & & & & 1.00 \\
\hline ?Castaneophyllum lonchitiforme & & & 1.00 & & & & & & & & & & & 1.00 \\
\hline Rosa lignitum / R. milosii & & 0.50 & 0.50 & & & & & & & & & & & 1.00 \\
\hline Symplocos oligocaenica & & & 1.00 & & & & & & & & & & & 1.00 \\
\hline Taxodium dubium & & & & & & & & & & 1.00 & & & & 1.00 \\
\hline Tetraclinis salicornioides & 1.00 & & & & & & & & & & & & & 1.00 \\
\hline
\end{tabular}




\begin{tabular}{|c|c|c|c|c|c|c|c|c|c|c|c|c|c|c|}
\hline \multirow{2}{*}{$\begin{array}{l}\text { site: Roudníky } \\
\text { Taxa }\end{array}$} & \multicolumn{8}{|c|}{ ZONAL } & \multicolumn{5}{|c|}{ AZONAL } & \multirow[b]{2}{*}{ 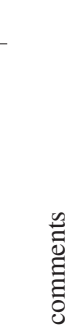 } \\
\hline & $\begin{array}{l}I_{z}^{\prime} \\
\text { O }\end{array}$ & $\stackrel{\oplus}{\oplus}$ & 䍃 & $\vec{\sim}$ & 亗 & 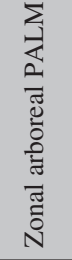 & 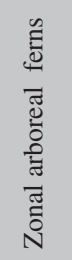 & 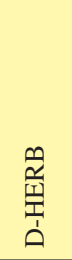 & 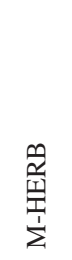 & 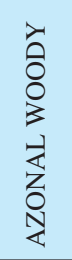 & 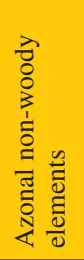 & 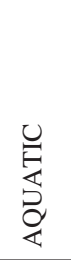 & 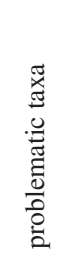 & \\
\hline Torreya bilinica & 1.00 & & & & & & & & & & & & & 1.00 \\
\hline Toxicodendron herthae & & 1.00 & & & & & & & & & & & & 1.00 \\
\hline Ulmus fischeri & & 0.50 & & & & & & & & 0.50 & & & & 1.00 \\
\hline cf. "Viburnum" atlanticum & & 0.50 & 0.50 & & & & & & & & & & & 1.00 \\
\hline Zelkova zelkovifolia & & 1.00 & & & & & & & & & & & & 1.00 \\
\hline Ziziphus ziziphoides & & & 0.50 & 0.50 & & & & & & & & & & 1.00 \\
\hline cf. Dicotylophyllum ungeri & & 1.00 & & & & & & & & & & & & 1.00 \\
\hline & & & & & & & & & & & & & & 44.00 \\
\hline Sum of taxa & 5.00 & 19.50 & 9.50 & 1.50 & 2.50 & 0.00 & 0.00 & 0.00 & 0.00 & 5.00 & 0.00 & 1.00 & 1.00 & 45.00 \\
\hline Sum zonal taxa & & & & & & & & & & & & & & 38.00 \\
\hline Percentage of zonal taxa & 13.16 & 51.32 & 25.00 & 3.95 & 6.58 & 0.00 & 0.00 & 0.00 & 0.00 & & & & & 100.00 \\
\hline Sum zonal woody angiosperms & & & & & & & & & & & & & & 33.00 \\
\hline $\begin{array}{l}\text { Percentage of zonal woody } \\
\text { angiosperms }\end{array}$ & & 59.09 & 28.79 & 4.55 & 7.58 & 0.00 & & & & & & & & 100.00 \\
\hline Sum of $\%$ SCL+LEG & 12.12 & & & & & & & & & & & & & \\
\hline Sum of $\%$ D-HERB+M-HERB & 0.00 & & & & & & & & & & & & & \\
\hline
\end{tabular}




\section{Appendix 2B}

List of plant taxa occurring in the studied floras from Větruše and their scoring according to the IPR-vegetation analysis.

\begin{tabular}{|c|c|c|c|c|c|c|c|c|c|c|c|c|c|c|}
\hline \multirow{2}{*}{$\begin{array}{l}\text { site: Větruše } \\
\text { Taxa }\end{array}$} & \multicolumn{7}{|c|}{ ZONAL } & \multicolumn{7}{|c|}{ AZONAL } \\
\hline & 岂 & $\stackrel{\oplus}{\oplus}$ & 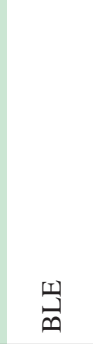 & 己̈ & 式 & 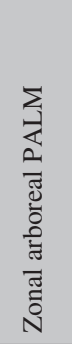 & 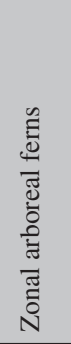 & 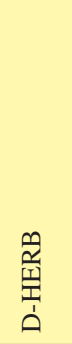 & $\begin{array}{l}\frac{n}{2} \\
\text { 㝰 } \\
\sum_{\Sigma}^{1}\end{array}$ & 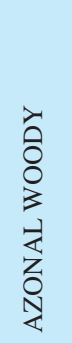 & 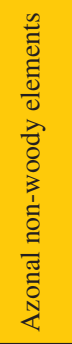 & 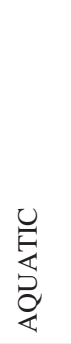 & 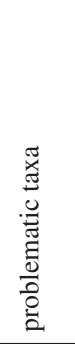 & 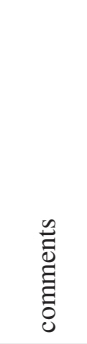 \\
\hline Acer sp. & & 1.00 & & & & & & & & & & & & 1.00 \\
\hline Alnus kefersteinii & & 1.00 & & & & & & & & & & & & 1.00 \\
\hline Carya fragiliformis & & 1.00 & & & & & & & & & & & & 1.00 \\
\hline Craigia bronii & & 0.50 & & & & & & & & 0.50 & & & & 1.00 \\
\hline $\begin{array}{l}\text { Daphnogene cinnamomifolia vel cf. } \\
\text { Matudaea menzelii }\end{array}$ & & & 1.00 & & & & & & & & & & & 1.00 \\
\hline Engelhardia orsbergensis & & 0.50 & 0.50 & & & & & & & & & & & 1.00 \\
\hline Juniperus pauli & 1.00 & & & & & & & & & & & & & 1.00 \\
\hline Laurophyllum cf. acutimontanum & & & 1.00 & & & & & & & & & & & 1.00 \\
\hline Liriodendron sp. & & 1.00 & & & & & & & & & & & & 1.00 \\
\hline Monocotyledonae gen. indet. & & & & & & & & & & & 1.00 & & & 1.00 \\
\hline Ostrya atlantidis & & 1.00 & & & & & & & & & & & & 1.00 \\
\hline Platanus neptuni & & 0.50 & & & & & & & & 0.50 & & & & 1.00 \\
\hline Rosa lignitum & & 0.50 & 0.50 & & & & & & & & & & & 1.00 \\
\hline Taxodium dubium & & & & & & & & & & 1.00 & & & & 1.00 \\
\hline Tetraclinis salicornioides & 1.00 & & & & & & & & & & & & & 1.00 \\
\hline Ulmus fischeri & & 0.50 & & & & & & & & 0.50 & & & & 1.00 \\
\hline Zelkova zelkovifolia & & 1.00 & & & & & & & & & & & & 1.00 \\
\hline Sum of taxa & 2.00 & 8.50 & 3.00 & 0.00 & 0.00 & 0.00 & 0.00 & 0.00 & 0.00 & 2.50 & 1.00 & 0.00 & 0.00 & 17.00 \\
\hline Sum zonal taxa & & & & & & & & & & & & & & 13.50 \\
\hline Percentage of zonal taxa & 14.81 & 62.96 & 22.22 & 0.00 & 0.00 & 0.00 & 0.00 & 0.00 & 0.00 & & & & & 100.00 \\
\hline Sum zonal woody angiosperms & & & & & & & & & & & & & & 11.50 \\
\hline $\begin{array}{l}\text { Percentage of zonal woody } \\
\text { angiosperms }\end{array}$ & & 73.91 & 26.09 & 0.00 & 0.00 & 0.00 & & & & & & & & 100.00 \\
\hline
\end{tabular}

\begin{tabular}{ll} 
Sum of \% SCL+LEG & 0.00 \\
Sum of \% D-HERB+M-HERB & 0.00 \\
\hline
\end{tabular}




\section{Appendix 3}

Results of the IPR-vegetation analysis and cluster analysis (Ward's method, squared Euclidean distance) of the studied late Eocene and early Oligocene floras from Northern Bohemia and Saxony and modern tropical, subtropical and temperate vegetation types from China and Japan (sensu Teodoridis et al. 2011b, 2012). DATA source for the cluster analysis was values of the percentage of BLD, BLE and SCL+LEG components. Abbreviations: BLDF (broad-leaved deciduous forests), MMF (mixed mesophytic forests), BLEF (broad-leaved evergreen forests), ShSF (subhumid sclerophyllous forests), MMF/BLEF (transitional/ecotonal/zonal vegetation types of MMF and BLEF), and BLDF/MMF (transitional/ecotonal/zonal vegetation types of BLDF and MMF).

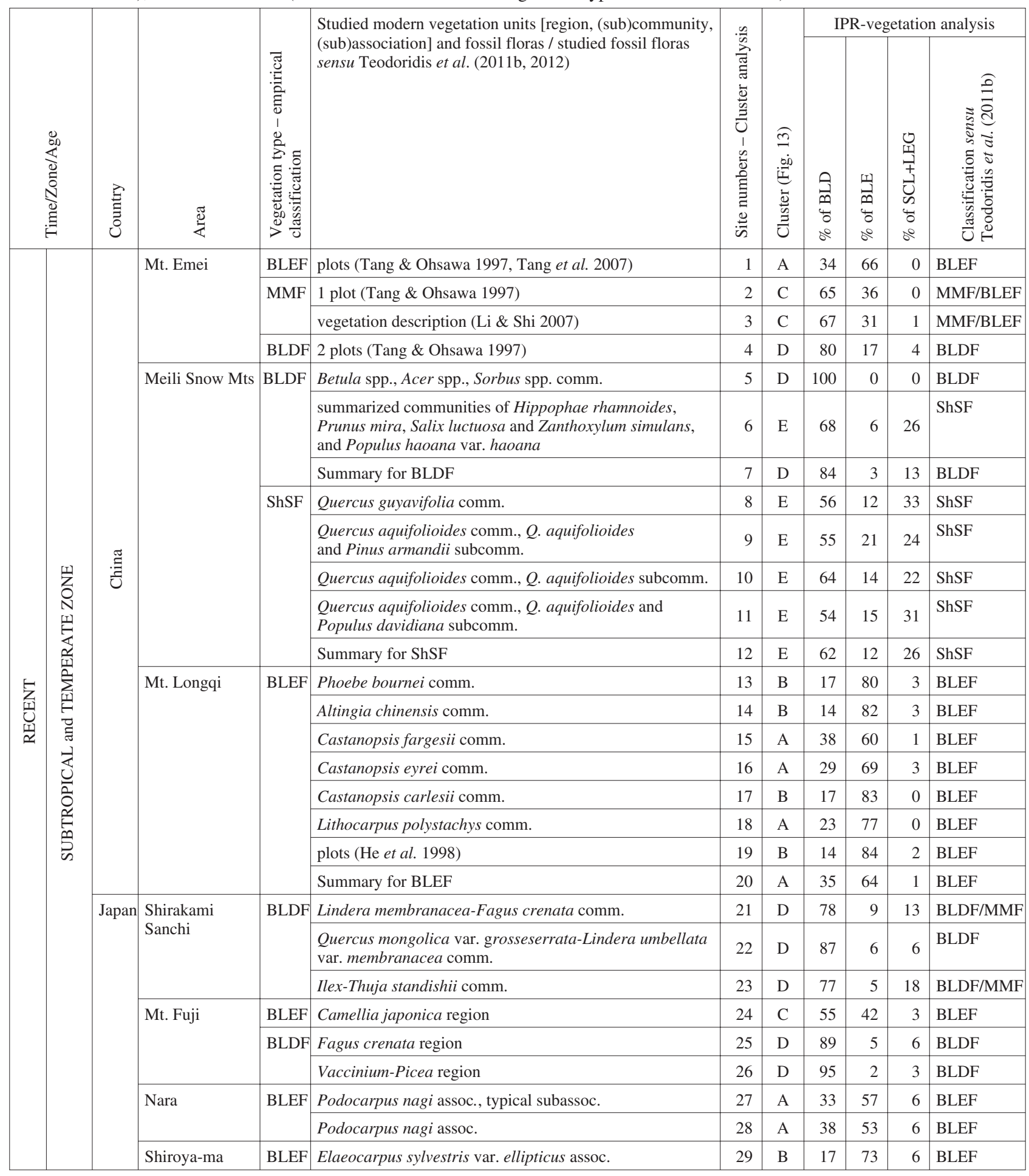




\begin{tabular}{|c|c|c|c|c|c|c|c|c|c|c|c|}
\hline \multirow{2}{*}{\multicolumn{2}{|c|}{ 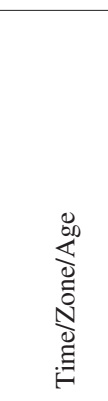 }} & \multirow[b]{2}{*}{ 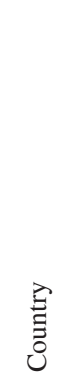 } & \multirow[b]{2}{*}{$\stackrel{\mathbb{J}}{\stackrel{Z}{Z}}$} & \multirow[b]{2}{*}{ 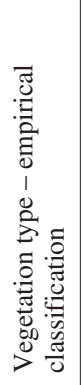 } & \multirow{2}{*}{$\begin{array}{l}\text { Studied modern vegetation units [region, (sub)community, } \\
\text { (sub)association] and fossil floras / studied fossil floras } \\
\text { sensu Teodoridis et al. }(2011 \mathrm{~b}, 2012)\end{array}$} & \multirow[b]{2}{*}{ 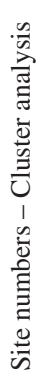 } & \multirow[b]{2}{*}{ 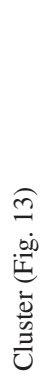 } & \multicolumn{4}{|c|}{ IPR-vegetation analysis } \\
\hline & & & & & & & & 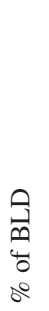 & 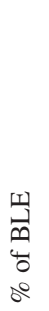 & 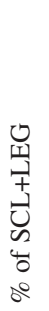 & 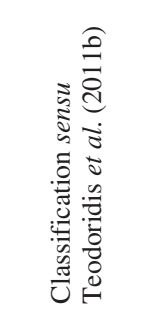 \\
\hline \multirow{18}{*}{ 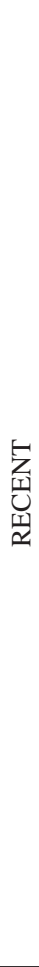 } & \multirow{11}{*}{ 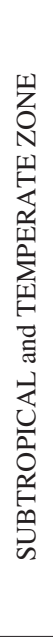 } & \multirow{11}{*}{$\begin{array}{l}\tilde{\Xi} \\
\stackrel{\tilde{\Xi}}{\sim}\end{array}$} & \multirow{11}{*}{$\begin{array}{l}\text { Yakushima } \\
\text { Island }\end{array}$} & \multirow[t]{6}{*}{ BLEF } & Ficus superba var. japonica-Persea thunbergii assoc. & 30 & $\mathrm{~B}$ & 17 & 81 & 2 & BLEF \\
\hline & & & & & Tarenna-Castanopsis sieboldii assoc. & 31 & $\mathrm{~B}$ & 16 & 80 & 5 & BLEF \\
\hline & & & & & Hydrangea-Castanopsis sieboldii assoc. & 32 & $\mathrm{~B}$ & 14 & 80 & 6 & BLEF \\
\hline & & & & & Distylium-Quercus salicina assoc., typical subassoc. & 33 & $\mathrm{~B}$ & 14 & 81 & 6 & BLEF \\
\hline & & & & & $\begin{array}{l}\text { Distylium-Quercus salicina assoc., Maesa japonica } \\
\text { subassoc. }\end{array}$ & 34 & $\mathrm{~B}$ & 19 & 76 & 5 & BLEF \\
\hline & & & & & Summary for Distylium-Quercus salicina assoc. & 35 & $\mathrm{~B}$ & 20 & 75 & 5 & BLEF \\
\hline & & & & \multirow[t]{5}{*}{ MMF } & $\begin{array}{l}\text { Eurya-Cryptomeria japonica assoc., Dryopteris nippoensis } \\
\text { subassoc. }\end{array}$ & 36 & $\mathrm{C}$ & 56 & 32 & 12 & MMF/BLEF \\
\hline & & & & & Eurya-Cryptomeria japonica assoc., typical subassoc. & 37 & $\mathrm{C}$ & 56 & 27 & 17 & MMF \\
\hline & & & & & $\begin{array}{l}\text { Eurya-Cryptomeria japonica assoc., Tsuga sieboldii } \\
\text { subassoc. }\end{array}$ & 38 & $\mathrm{C}$ & 43 & 42 & 15 & BLEF \\
\hline & & & & & $\begin{array}{l}\text { Eurya-Cryptomeria japonica assoc., Carex morrowii var. } \\
\text { laxa subassoc. }\end{array}$ & 39 & $\mathrm{C}$ & 53 & 31 & 16 & MMF/BLEF \\
\hline & & & & & Summary for Eurya-Cryptomeria japonica assoc. & 40 & $\mathrm{C}$ & 43 & 38 & 19 & MMF/BLEF \\
\hline & \multirow{7}{*}{ 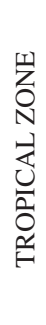 } & \multirow{7}{*}{ : } & \multirow{2}{*}{\multicolumn{2}{|c|}{ Jianfengling }} & Tropical lowland rain forest & 41 & $\mathrm{~B}$ & 5 & 95 & 1 & BLEF \\
\hline & & & & & Tropical montane rain forest & 42 & $\mathrm{~B}$ & 1 & 98 & 0 & BLEF \\
\hline & & & \multirow{5}{*}{\multicolumn{2}{|c|}{ Xishuangbanna }} & Tropical seasonal rain forest & 43 & $\mathrm{~B}$ & 9 & 89 & 0 & BLEF \\
\hline & & & & & Tropical montane rain forest & 44 & $\mathrm{~B}$ & 3 & 97 & 0 & BLEF \\
\hline & & & & & Tropical seasonal moist forest & 45 & A & 26 & 73 & 1 & BLEF \\
\hline & & & & & Monsoon forest & 46 & $\mathrm{C}$ & 59 & 40 & 1 & BLEF \\
\hline & & & & & Tropical montane broad-leaved evergreen forest & 47 & $\mathrm{~B}$ & 9 & 91 & 0 & BLEF \\
\hline \multirow{18}{*}{ 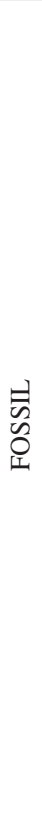 } & \multirow{6}{*}{ 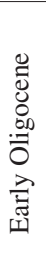 } & $\mathrm{D}$ & \multicolumn{3}{|l|}{ Seifhennersdorf } & 48 & $\mathrm{C}$ & 59 & 34 & 5 & MMF/BLEF \\
\hline & & $\mathrm{CZ}$ & \multicolumn{3}{|l|}{ Holý Kluk } & 49 & $\mathrm{C}$ & 65 & 29 & 6 & MMF \\
\hline & & $\mathrm{D}$ & \multicolumn{3}{|c|}{ Hammerunterwiesenthal } & 50 & $\mathrm{C}$ & 55 & 36 & 3 & MMF/BLEF \\
\hline & & $\mathrm{CZ}$ & \multicolumn{3}{|c|}{ Kundratice } & 51 & $\mathrm{C}$ & 58 & 35 & 6 & MMF/BLEF \\
\hline & & & \multicolumn{3}{|l|}{ Bechlejovice } & 52 & $\mathrm{C}$ & 63 & 27 & 10 & MMF \\
\hline & & $\mathrm{D}$ & Haselbach (Has & lbach Fl & & 53 & $\mathrm{C}$ & 50 & 42 & 4 & BLEF \\
\hline & & $\mathrm{CZ}$ & Větruše & & & 54 & $\mathrm{D}$ & 74 & 26 & 0 & MMF \\
\hline & & $\mathrm{CZ}$ & Roudníky & & & 55 & $\mathrm{C}$ & 58 & 30 & 13 & MMF \\
\hline & & $\mathrm{D}$ & Kayna-Süd & & & 56 & B & 18 & 82 & 0 & BLEF \\
\hline & & & Knau & & & 57 & B & 8 & 92 & 0 & BLEF \\
\hline & $\cong$ & & Klausa & & & 58 & $\mathrm{~A}$ & 24 & 65 & 0 & BLEF \\
\hline & 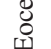 & & Phönix-Nord & & & 59 & $\mathrm{~A}$ & 25 & 74 & 1 & BLEF \\
\hline & Е & & Profen & & & 60 & $\mathrm{~A}$ & 21 & 77 & 0 & BLEF \\
\hline & $\vec{a}$ & & Haselbach (Zeit & Sand) & & 61 & $\mathrm{~B}$ & 13 & 80 & 0 & BLEF \\
\hline & & $\mathrm{CZ}$ & Kučlín & & & 62 & $\mathrm{C}$ & 46 & 41 & 12 & BLEF \\
\hline & & & Staré Sedlo & & & 63 & A & 25 & 59 & 3 & BLEF \\
\hline & & & Český Chloume & & & 64 & A & 22 & 66 & 0 & BLEF \\
\hline & & & Nový Kostel & & & 65 & $\mathrm{~A}$ & 34 & 66 & 0 & BLEF \\
\hline
\end{tabular}

